\title{
Radioactive Testing Results in Support of the In-Tank Precipitation Facility
}

by

D. T. Hobbs

Westinghouse Savannah River Company

Savannah River Site

Aiken, South Carolina 29808

M. J. Bames

R. A. Peterson

C. L. Crawford

DOE Contract No. DE-AC09-96SR18500

This paper was prepared in connection with work done under the above contract number with the $U$. $S$. Department of Energy. By acceptance of this paper, the publisher and/or recipient acknowledges the U.S. Government's right to retain a nonexclusive, royalty-free license in and to any copyright covering this paper, along with the right to reproduce and to authorize others to reproduce all or part of the copyrighted paper.

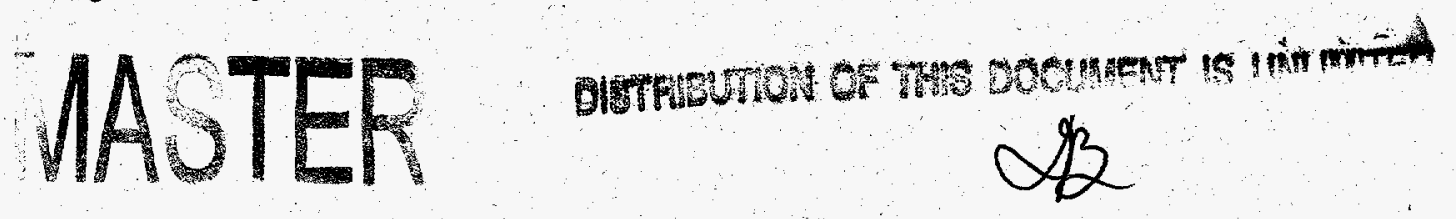




\section{DISCLAIMER}

This report was prepared as an account of work sponsored by an agency of the United States Government. Neither the United States Government nor any agency thereof, nor any of their employees, makes any warranty, express or implied, or assumes any legal liability or responsibility for the accuracy, completeness, or usefulness of any information, apparatus, product, or process disclosed, or represents that its use would not infringe privately owned rights. Reference herein to any specific commercial product, process, or service by trade name, trademark, manufacturer, or otherwise does not necessarily constitute or imply its endorsement, recommendation, or favoring by the United States Government or any agency thereof. The views and opinions of authors expressed herein do not necessarily state or reflect those of the United States Government or any agency thereof.

This report has been reproduced directly from the best available copy.

Available to DOE and DOE contractors from the Office of Scientific and Technical Information, P.O. Box 62, Oak Ridge, TN 37831; prices available from (615) 576-8401.

Available to the public from the National Technical Information Service, U.S. Department of Commerce, 5285 Port Royal Road, Springfield, VA 22161. 


\section{DISCLAIMER}

Portions of this document may be illegible electronic image products. Images are produced from the best available original document. 
WSRC-TR-98-00070

Revision 0

\section{Radioactive Testing Results in Support of the In-Tank Precipitation Facility}
D. T. Hobbs
M. J. Barnes
R. A. Peterson
C. L. Crawford

Publication Date: April 2, 1998

Westinghouse Savannah River Company Savannah River Technology Center

$A$ iken, SC 29808

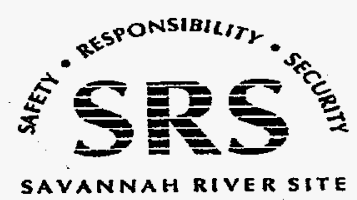

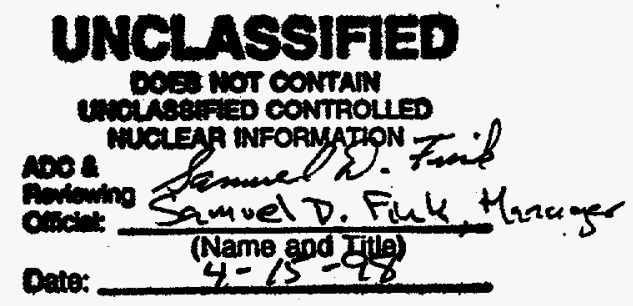


WSRC-TR-00070

page 2 of 68

Revision 0

Radioactive Testing Results in Support of the In-Tank Precipitation Facility

Authors
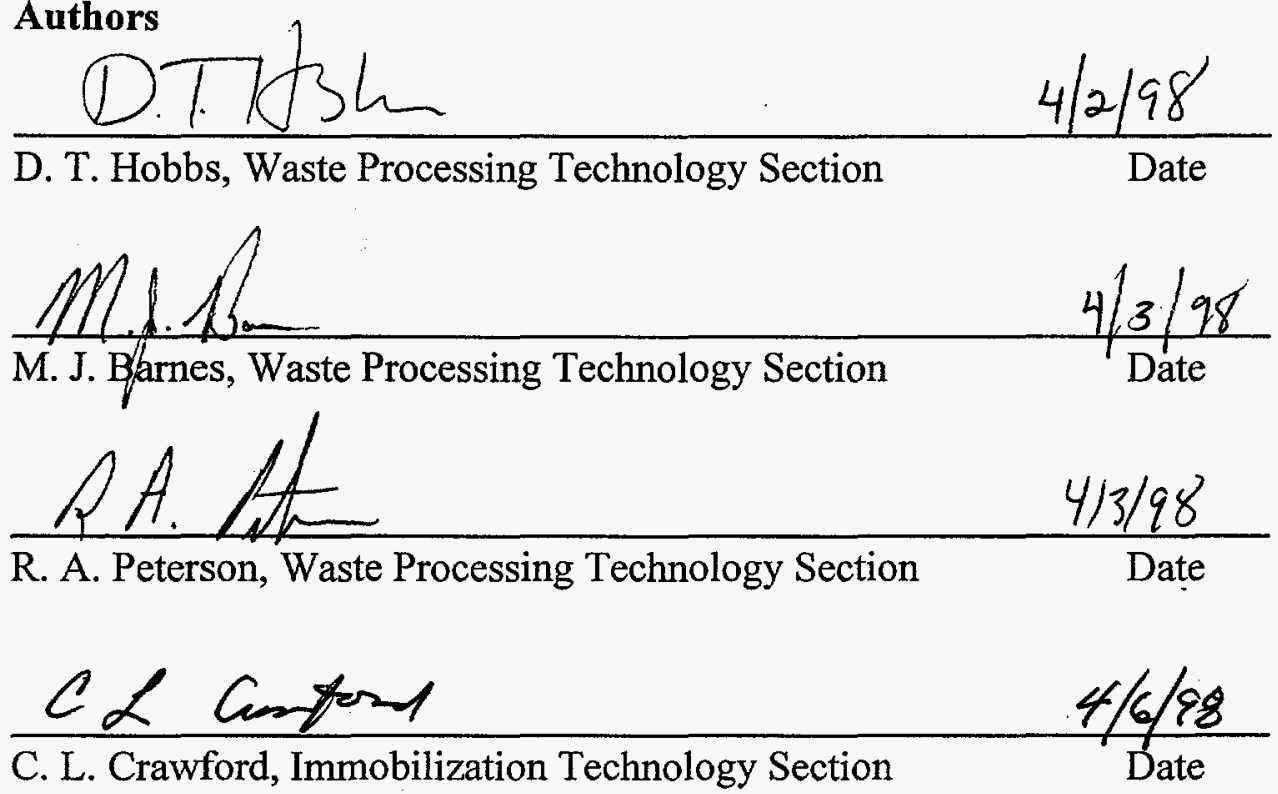

Design Check

$\frac{\text { Resell \& Codling }}{\text { R. E. Sibling, Immobilization Technology Section }} \frac{4 / 7 / 1998}{\text { Date }}$ (per Manual E7, Procedure 2.40)

Approvals
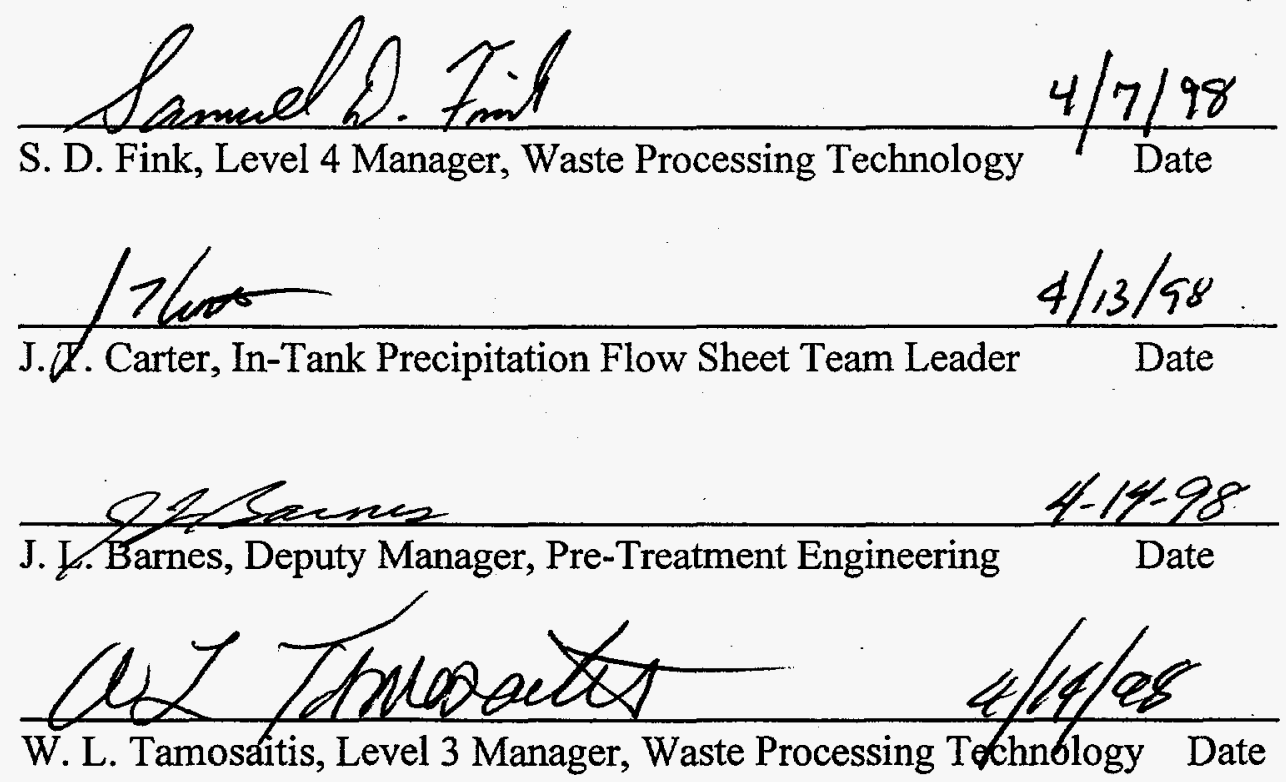


\subsection{Summary}

A series of twelve tests examined benzene generation rates with radioactive materials simulating the planned Batches 2 through 4 that complete Cycle 1 for the In-Tank Precipitation (ITP) facility. The following observations come from these tests.

- At bounding facility temperatures and high sludge solids content (i.e., $45^{\circ} \mathrm{C}$ and $>780 \mathrm{mg} / \mathrm{L}$ sludge), seven of the 12 tests exhibited calculated benzene formation rates in excess of $7 \mathrm{mg} / \mathrm{L}-\mathrm{h}$ from decomposition of excess NaTPB based on soluble boron measurements. These results imply the need for changes in current process configuration before resumption of operations.

- Removal efficiency for cesium meets Saltstone criteria at molar NaTPB excesses as low as $8 \%$ of the theoretical equivalent.

- When rapid decomposition (i.e., $>7 \mathrm{mg} / \mathrm{L}-\mathrm{h}$ calculated benzene formation) of excess sodium tetraphenylborate (NaTPB) occurred, the soluble cesium-137 concentration rose above the Saltstone criteria (i.e., $30 \mathrm{nCi} / \mathrm{g}$ ) in a relatively short period of 14 days.

- Direct benzene generation measurements did not agree well with those determined from soluble boron concentrations in the Batch 2 test.

- Batch 3 and Batch 4 compositions appeared more reactive than Batch 2 when compared at the same low molar excess NaTPB conditions. The greater reactivity is attributed to differences in the chemical compositions, specifically higher concentrations of several metals (i.e., $\mathrm{Cu}, \mathrm{Hg}, \mathrm{Ce}, \mathrm{Mo}, \mathrm{Mn}, \mathrm{Ni}$, and $\mathrm{Zn}$ ) and major salt components (i.e., hydroxide, nitrate, nitrite).

- Three tests provided measurements of decomposition rate for the potassium and cesium tetraphenylborate ((K/CS)TPB) in absence of excess NaTPB. At bounding facility temperatures and high sludge solids content (i.e., $45^{\circ} \mathrm{C}$ and $>780 \mathrm{mg} / \mathrm{L}$ sludge), the $(\mathrm{K} / \mathrm{Cs}) \mathrm{TPB}$ precipitate decomposed at a rate slower than $4.5 \mathrm{mg} / \mathrm{L}-\mathrm{h}$ benzene equivalent.

- The measured reactions followed an induction period of between 0 and 1285 hours. This induction behavior did not correlate well with any measured system parameter or concentration of any identified component. Examination of phenol yield data indirectly suggests a possible role of oxygen or redox state with the induction period.

- Addition of monosodium titanate is not required in Batch 2, but is required in Batches 3 and 4 to meet Saltstone criteria for Sr-90 and total alpha activity.

Comparison of these radioactive tests with simulant experiments provided the following observations.

- The radioactive system contained far less palladium than the concentration typically used in the non-radioactive testing with ECC sludge (i.e., $0.092-0.26 \mathrm{mg} / \mathrm{L}$ in the radioactive tests compared to $2.60 \mathrm{mg} / \mathrm{L}$ in simulant tests).

- The radioactive system contained higher concentrations (i.e., 2 to $160 \mathrm{X}$ ), relative to ECC concentrations of selected metals (i.e., $\mathrm{As}, \mathrm{Ca}, \mathrm{Cd}, \mathrm{Ce}, \mathrm{Co}, \mathrm{Cu}, \mathrm{La}, \mathrm{Mo}, \mathrm{Se}$, and $\mathrm{Sr}$ ) than previous simulant tests. 
- The radioactive system contained lower concentrations (i.e., 2 to $250 \mathrm{X}$ ), relative to $\mathrm{ECC}$ concentrations of selected metals (i.e., $\mathrm{Ag}, \mathrm{Fe}, \mathrm{Hg}, \mathrm{Mn}, \mathrm{Ni}, \mathrm{Pd}$, $\mathrm{Ti}$ and $\mathrm{Zr}$ ) than previous simulant tests.

- The radioactive system contained eight metals (i.e.W, V, Tc, W, Re, Os, Ir , Pt and $\mathrm{Au}$ ) not added in previous simulant tests.

- Decomposition rates for excess NaTPB in the radioactive tests approximately match rates from simulant testing containing about 10 to 30 times the concentration of total palladium.

- Decomposition rates for $(\mathrm{K} / \mathrm{Cs}) \mathrm{TPB}$ in the radioactive tests approximately match rates from simulant testing containing 150 times the concentration of total palladium.

These findings suggest the following additional investigations.

- Conduct additional radioactive waste tests to examine the reaction rates in systems with inorganic sludge removed.

- Examine the benefit of removal of soluble metals, especially palladium, copper and mercury.

- Measure the relative catalytic influence of selected metals (i.e., W, V, Ce, Pt, Rh and Ir) on the decomposition rate of excess NaTPB.

- Examine whether palladium catalyzed decomposition of excess NaTPB increases in the presence of selected metals (e.g., $\mathrm{Hg}, \mathrm{Cd}, \mathrm{Cr}$ and $\mathrm{Mo}$ ).

- Conduct tests with near continuous gas phase benzene measurements and periodic liquid phase soluble boron measurements to confirm accuracy and precision of both analytical methods.

- Investigate methods to measure the redox potential and oxygen content of reacting systems.

- Develop improved noble metal analyses, and especially palladium, at concentrations of $1-100 \mu \mathrm{g} / \mathrm{L}$ in nominal $5 \mathrm{M}$ sodium solutions.

\subsection{Introduction}

The In-Tank Precipitation (ITP) facility initiated radioactive operation in August, 1995. During pump operation in December 1995, benzene evolution from Tank 48H exceeded expectations, although the vapor phase benzene concentration never approached the operational safety limit. Subsequent investigations revealed catalytic decomposition of excess sodium tetraphenylborate produced the benzene [1]

The Defense Nuclear Facilities Safety Board (DNFSB) issued Recommendation 96-1[2] suggesting suspension of ITP operations pending an improved understanding for the mechanisms of benzene generation, retention and release. The Department of Energy developed a plan to resolve the issues raised by the DNFSB based on a revised safety

strategy and a combination of bench, pilot and plant-scale tests [3]. The implementation plan includes bench-scale tests using radioactive waste to confirm that benzene generation rates using simulants bound the next three planned batches of Cycle 1. This report documents those radioaetive tests, fulfilling a request by CST Engineering and the ITP Flow Sheet Team [4]. During the tests, the experimental methodology was modified eliminating the capability 
of obtaining meaningful data on Cs-137 increases during conditions simulating washing operations. Therefore, simulation of the washing operation over a realistic cycle time was dropped from the Cycle 1 Demonstration scope. Tests investigating benzene generation rates in filtrates (i.e., simulating Tank $50 \mathrm{H}$ operations) have been delayed and will be reported in a later document.

\subsection{Experimental}

Samples of waste from Tanks $48 \mathrm{H}, 49 \mathrm{H}, 25 \mathrm{~F}, 32 \mathrm{H}, 34 \mathrm{~F}$ and $39 \mathrm{H}$ were received at SRTC in February and April, 1997[5]. Multiple samples from an individual tank were combined into a single composite sample and stored in polyethylene (PE) bottles. Sample identification numbers for each composite material are provided below. Each composite sample was analyzed for radiochemical and chemical composition[6-7]. Appendices 9.1-9.6 provide the analytical results for each composite.

$\begin{array}{lc}\frac{\text { Tank }}{48 \mathrm{H}} & \text { Composite Identification } \\ 49 \mathrm{H} & \text { DTH-48-001 } \\ 25 \mathrm{~F} & \text { DTH-49-001 } \\ 32 \mathrm{H} & \text { DTH-25-001 } \\ 34 \mathrm{~F} & \text { DTH-32-001 } \\ 39 \mathrm{H} & \text { DTH-34-001 } \\ & \text { DTH-39-001 }\end{array}$

Since testing started in May, 1997, a mixture of the Tank $34 \mathrm{~F}$ and $39 \mathrm{H}$ composite samples was prepared to simulate the Tank $39 \mathrm{H}$ composition after the planned transfer of waste from Tank 34F into Tank 39H completed in August, 1997. This composite is referred to as Tank 34F/39H and stored in PE bottle labeled as DTH-39-002. The composite contains a volume ratio of Tank $34 \mathrm{~F}$ to Tank $39 \mathrm{H}$ of 1.96.

Catalyst identification studies [8-10] implicated sludge as a key source of catalytic activity. A target for the sludge concentration in the radioactive tests of $1.0 \mathrm{~g} / \mathrm{L}$ on an added salt solution basis is about 2.5 times higher than the current ITP process requirement limit of 400 $\mathrm{mg} / \mathrm{L}[11]$. Tanks $4 \mathrm{~F}$ and $11 \mathrm{H}$ sludge samples were added in Batch 2-4 since these materials would be comparable to the sludge transferred with supernatant liquids transferred from Tanks 25F, 34F, 32H and 39H. Experiments used archived sludge samples from Tanks 4F and $11 \mathrm{H}$ stored at SRTC. Each sludge sample was removed from its storage container and lightly crushed with mortar and pestle into a fine powder. Portions of each sludge were dissolved using either Aqua regia or sodium peroxide fusion dissolution methods and the resulting solutions analyzed for radiochemical and chemical composition. Appendices 9.7 and 9.8 provide analytical results for these materials.

Inhibited water was used to dilute the waste in each test to provide a sodium ion concentration of between 5.0 and 5.2 molar. The inhibited water consisted of a dilute sodium hydroxide $(0.021 \mathrm{M})$ and sodium nitrite $(0.0142 \mathrm{M})$ in deionized distilled water. The inhibited water solution was stored in a PE bottle under argon until used.

The quantity of NaTPB needed to precipitate cesium and potassium was determined by the 'NaTPB Demand' method developed by C. Coleman of the ADS. In this method, a filtered 
sample of the test slurry is diluted to a low ionic strength (i.e., high NaTPB solubility) and a dilute solution of reagent grade NaTPB added to precipitate all of the cesium and potassium. The solids are collected on a preweighed filter membrane, washed with deionized water and dried at $45^{\circ} \mathrm{C}$ to constant weight.

Tests used two sources of NaTPB. A stock solution of NaTPB was prepared by combining residual solution samples of NaTPB received from Holly Oak Chemical, Inc (Batches \# D1526 and D1558 - ITP \#'s 9700009, 9700010, 9700284 and 9700285). This solution was determined to have a NaTPB concentration of $0.556 \pm 0.030 \mathrm{M}$. The other source of NaTPB was solid material received from Aquafine (Batch \#CT22-911218 Drum \#1797-1870, Sample \# AQA22, ITP \# 9501228). Analysis of the Aquafine material indicated a chemical purity of $79.2 \%$ by weight. The material contained small quantities of $3 \mathrm{~PB}, 2 \mathrm{~PB}, 1 \mathrm{~PB}$ and phenol. Other chemical impurities were not identified.

Test slurries were sampled periodically using a $10-\mathrm{mL}$ plastic syringe equipped with a stainless steel needle. The sample was filtered through a $0.45-\mu \mathrm{m}$ pore size disposable Nalgene ${ }^{\circledR}$ filter (cellulose nitrate membrane). The filtered liquid was then analyzed for Cs137 by gamma spectroscopy, for boron by inductively coupled plasma emission spectroscopy (ICP-ES), for potassium by atomic absorption spectroscopy (AAS), and for NaTPB, 3PB, $2 \mathrm{~PB}, 1 \mathrm{~PB}$ and phenol by high performance liquid chromatography (HPLC). Prior to the ICPES and AAS analyses, a filtered liquid sample was digested to destroy all organic compounds. Two digestion methods were used; (1) sodium peroxide fusion and (2) microwave heating in acid.

The original radioactive test plan referred to as the Cycle 1 Demonstration consisted of a series of sequential, bench-scale tests using radioactive waste from tanks comprising Batches 2 through 4 which complete Cycle 1 . Table I provides the components and planned quantities for Batches 2 through 4[12].

Initial radioactive testing was performed in a specially constructed glass reactor equipped with a magnetic stirring bar in Cell 11 of the Shielded Cells Facility in

773-A[13]. A schematic diagram of the testing equipment is provided in Figure 1. The dimensions of the reactor provide a surface area to volume ratio within a factor of 2 of that in the precipitation reactor (Tank $48 \mathrm{H}$ ) of the ITP facility. The reactor vessel includes an inlet for gas purging of the vapor space, an outlet for the purge gas including an air condenser, an inlet for sampling and liquid additions via glass buret, and an inlet for addition of materials and filtering disk for solids concentration after each batch. The gas purge system allows syringe sampling on the front side of the Shielded Cells. 
Table I. Cycle 1 Batches Recipes.

\begin{tabular}{lccc} 
& \multicolumn{2}{c}{ Quantities (kgal) } \\
Component & Batch 2 & $\frac{\text { Batch 3 }}{\text { Batch 4 }}$ & $\frac{119}{11}$ \\
Tank 48H & 106 & 0 & 0 \\
Tank 49H & 140 & 0 & 0 \\
Tank 25F & 170 & 240 & 210 \\
Tank 32H & 0 & 170 & 210 \\
Tank 39H & 0 & 115 & 135 \\
Inhibited Water & 150 & 20 & 22 \\
NaTPB & 41 & &
\end{tabular}

Nitrogen purge rate was set at nominally $10 \mathrm{~cm}^{3} / \mathrm{m}$ which results in a residence time in the reaction vessel similar to that in Tank $48 \mathrm{H}$. The glass reactor and gas water bottle (that humidifies purge gas) were placed in a water bath set to hold temperature at $45^{\circ} \mathrm{C}$. A ColeParmer ${ }^{\otimes}$ Polystat ${ }^{\circledR}$ Immersion Circulator, Model \# 12112-60, controlled the water bath temperature. An Omega RTD temperature probe and digital readout (MTE \# WP-652 and WP-653) measured the bath temperature with data recorded on a Dickinson Recorder, Model EL54LR24P (MTE \# WP654).

Prior to radioactive testing, the gas sampling system checked by placing a simulated ITP slurry in the reactor, initiating the nitrogen purge and analyzing the exiting purge gas for benzene and oxygen content. After 3 hours, a low concentration of benzene $(<1 \mathrm{ppm} \mathrm{v} / \mathrm{v})$ and low oxygen concentration $(1.4 \% \mathrm{v} / \mathrm{v})$ were detected in the gas samples, confirming the capability of detecting low benzene concentration and exclusion of oxygen from air by purging with nitrogen[14]. The measured oxygen concentration is higher than predicted $(0.6$ $\% \mathrm{v} / \mathrm{v})$ based on the number of vapor space volume changes. However, a substantial vapor volume in the buret which is not in the direct purge path, may be purged of oxygen more slowly than the remainder of the system resulting in the higher observed oxygen concentration than predicted.

Due to the limited solubility of NaTPB in the initial tests, projected changes in NaTPB and intermediate concentrations were smaller than known experimental error. Therefore, the test methodology was modified to add a larger excess of NaTPB and calculate benzene generation rates from soluble boron measurements. Boron leaching from glass vessels precluded the use of glassware. Accordingly, carbon steel vessels were used for the remaining tests. 
Figure 1A. Schematic Diagram of Radioactive Testing Equipment View of Equipment Inside Shielded Cell

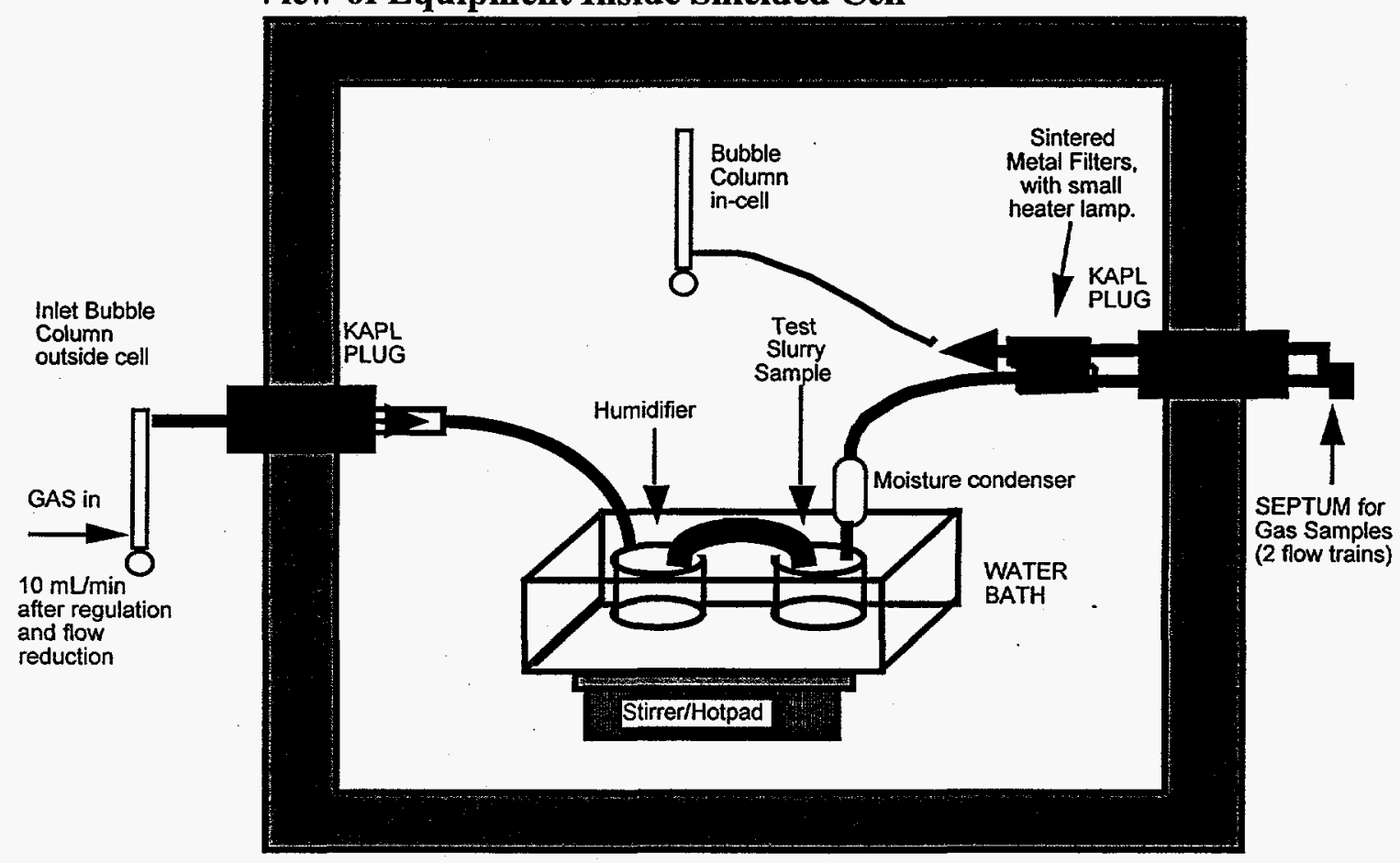

Figure 1B Schematic Diagram of Radioactive Testing Equipment Expanded View of Reaction Vessel

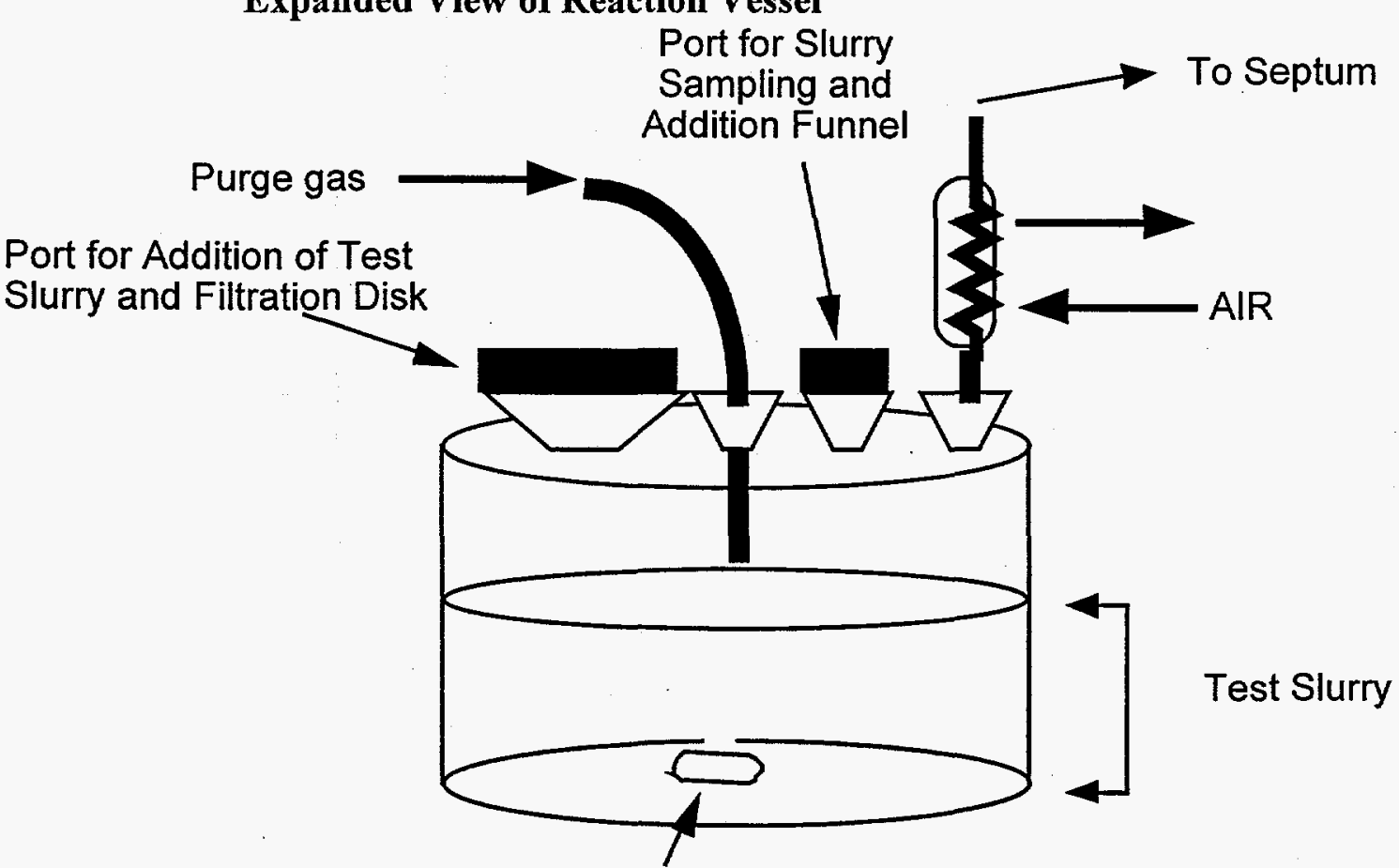

Magnetic Stir Bar (use with magnetic stirrer) 
The revised experimental methodolgy precluded direct measurement of benzene generation rates. The additional NaTPB added to enable determination of rates by indirect measurement also effectively eliminated obtaining any meaningful data on Cs-137 increases during conditions simulating washing operations. Therefore, simulation of the washing operation over a realistic cycle time was dropped from the Cycle 1 Demonstration scope.

The subsequent testing consisted of nine tests: Tests $2 \mathrm{~B}, 2 \mathrm{C}, 3 \mathrm{~A}, 3 \mathrm{~B}, 3 \mathrm{C}, 3 \mathrm{D}, 4 \mathrm{~A}, 4 \mathrm{~B}$, and $4 \mathrm{C}$ originating from the remaining Batch 2 slurry, conducted in carbon steel vessels $(140 \mathrm{~mL}$ capacity). Tests $2 \mathrm{~B}$ and $2 \mathrm{C}$ explored the effect of higher molar excess of NaTPB. Tests $3 \mathrm{~A}$ and $3 \mathrm{C}$ represent the sequential Batch 3 composition of Cycle 1 . The corresponding 'heel' for these tests originated from Test $2 \mathrm{~B}$ and residual Batch 2 materials, respectively. Tests $3 \mathrm{~B}$ and $3 \mathrm{D}$ represent a Batch 4 composition scaled appropriately for the Batch 3 'heel'. The 'heels' for these tests originated from Test $2 \mathrm{C}$ and residual Batch 2 materials, respectively. Tests $4 \mathrm{~A}$ and $4 \mathrm{C}$ represent the sequential Batch 4 composition of Cycle 1 . These tests are different from Tests $3 \mathrm{~B}$ and $3 \mathrm{D}$ in that the latter tests have materials that experienced a second precipitation stage. The 'heels' used in Tests $4 \mathrm{~A}$ and $4 \mathrm{C}$ originated from Tests $3 \mathrm{~A}$ and $3 \mathrm{C}$, respectively.

In addition to these nine tests, an additional test (referred to as Test 2.7) using the residual material of Tests $2 \mathrm{~B}$ and $2 \mathrm{C}$ (diluted to $2.7 \mathrm{M}$ sodium ion concentration) added to the Cycle 1 Demonstration. This test does not simulate any specific Cycle 1 batch but allows evaluation of the effect of ionic strength and a more direct comparison to previous simulant testing [15-17]. Tests conducted in carbon steel vessels were sealed under an air atmosphere and were not continuously agitated and were not purged with nitrogen. Tetraphenylborate decomposition and theoretical equivalent benzene generation rates were calculated based on determination of NaTPB, triphenylborane (3PB), diphenylborinic acid (2PB), phenylboronic acid (1PB), phenol, Cs-134/137 and total soluble boron measurements. Figure 2 provides a flowchart showing the Cycle 1 Demo testing.

All tests were conducted at a target temperature of $45^{\circ} \mathrm{C}$ except Test $2 \mathrm{~A}$ at $55^{\circ} \mathrm{C}$. Test $2 \mathrm{U}$ continued Batch 2 without agitation and nitrogen purge. Detailed descriptions of conditions used and events during each radioactive test are described below.

\section{Batch 2}

Tank 48H (106 mL), Tank 49H (140 mL) and Tank 25F (170 mL) samples were combined and mixed with inhibited water in a clean polyethylene (PE) bottle. This slurry is referred to as the Batch 2 Feed Slurry. After stirring for 48 hours, the slurry was sampled. The sample was filtered through a $0.45-\mu \mathrm{m}$ pore size disposable Nalgene ${ }^{\circledR}$ filter and analyzed for chemical content and tetraphenylborate demand. Twelve days after combining the Tank $48 \mathrm{H}$, Tank $49 \mathrm{H}$, Tank $25 \mathrm{~F}$ and inhibited water quantities, Tank $4 \mathrm{~F}$ sludge $(0.261 \mathrm{~g})$ was added to the Batch 2 Feed Slurry. The Batch 2 Feed Slurry was

then stored at ambient Cell 11 temperature in the PE bottle until used. Prior to use or sampling, the contents of the sample bottle were stirred for a minimum of 30 minutes. 
Batch 2 Feed Slurry $(730.5 \mathrm{~g}, 404 \mathrm{~mL})$ was placed in the radioactive testing equipment located in Cell 11 of the SRTC Shielded Cells Facility. On May 2, $44.3 \mathrm{~mL}$ of a $0.556 \mathrm{M}$ solution of sodium tetraphenylborate (Holly Oak) was added via a glass buret to the stirred Batch 2 Feed Slurry heated to $45^{\circ} \mathrm{C}$. The quantity of NaTPB to add in Batch 2 was previously determined by the 'NaTPB Demand' method. During and after NaTPB addition, the slurry was stirred continuously while purging the vessel with nitrogen. A second addition of $3.3 \mathrm{~mL}$ of the NaTPB solution (Holly Oak) was made on May 20, 1997 in the same manner as in the first addition to increase the liquid phase concentration of NaTPB.

Figure 2. Bench-scale Cycle 1 Demonstration Test Flowchart

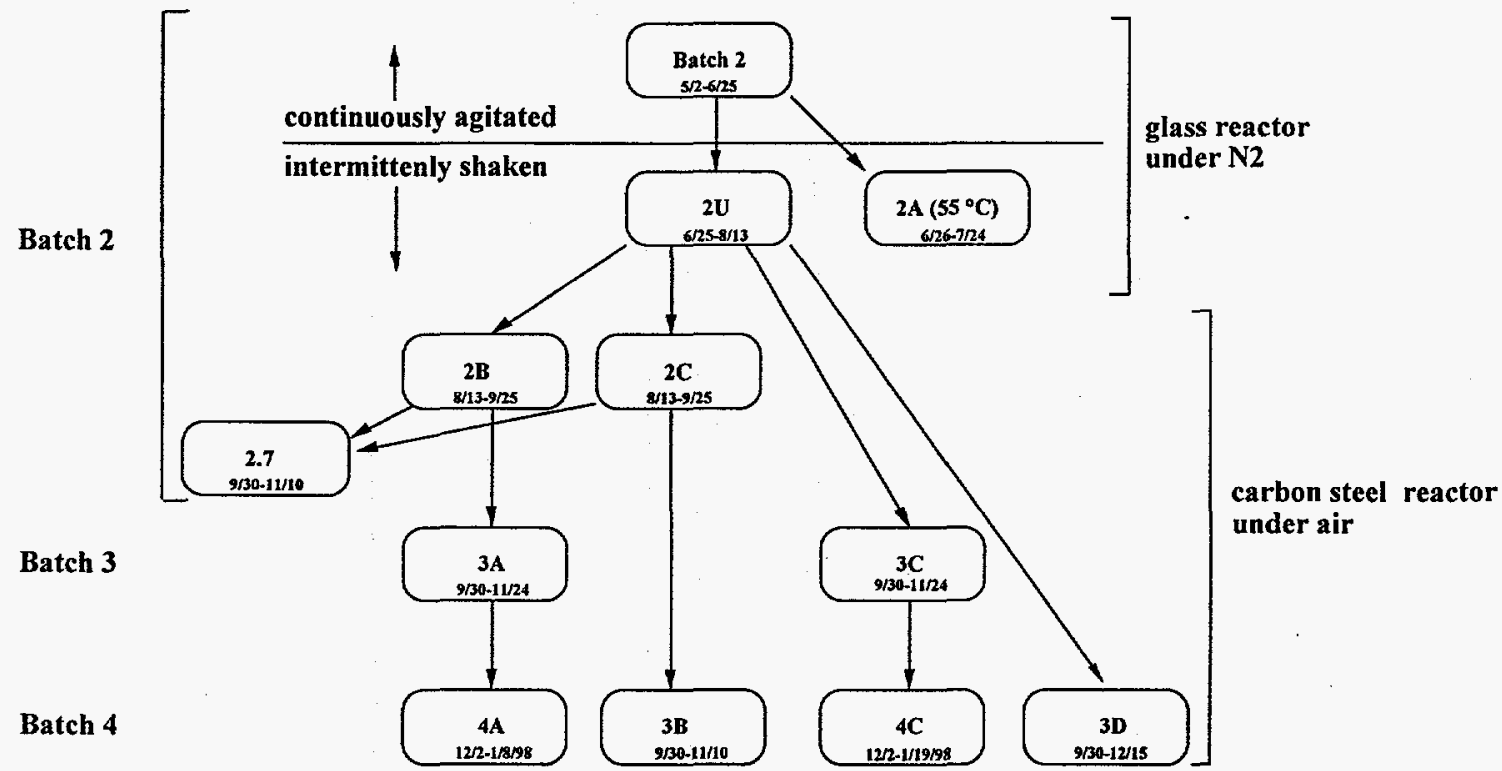

During sampling of the slurry on May 3,1997, the temperature setting on the temperature controller inadvertently changed and the water bath temperature increased, reaching a maximum of $73^{\circ} \mathrm{C}$. Upon observing the temperature increasing, the temperature controller was adjusted to reduce temperature. The reaction slurry exceeded $70^{\circ} \mathrm{C}$ for a total of about 15 minutes, exceeded $60^{\circ} \mathrm{C}$ for about 50 minutes and exceed $50^{\circ} \mathrm{C}$ for 90 minutes. No visible changes in the slurry appearance were apparent.

The water bath temperature ranged from 43.4 to $46.1{ }^{\circ} \mathrm{C}$ over the period from May 3 to June 17,1997 . On June 17,1997 , the temperature fell to $36^{\circ} \mathrm{C}$ for 12.5 hours. The controller was reset and the temperature rose briefly (less than 10 minutes) to a peak of $52^{\circ} \mathrm{C}$ before stabilizing at $45^{\circ} \mathrm{C}$. From June 18,1997 until July 23,1997 , the temperature ranged from 43.1 to $46.0^{\circ} \mathrm{C}$. On July 23,1997 , the temperature controller was accidentally touched resulting in the water bath reaching a peak of $50.7^{\circ} \mathrm{C}$ before quickly stabilizing at $45^{\circ} \mathrm{C}$. From July 23,1997 to August 13, 1997, the temperature ranged from 44.1 to $46.6^{\circ} \mathrm{C}$. 
Samples of the purge gas exiting the reactor were taken once or twice daily excluding weekends and holidays using 250- $\mu \mathrm{L}$ gas-tight Precision Pressure Lok ${ }^{\circledR}$ syringes. Benzene concentrations were determined within 30 minutes of sampling using a HNU Systems Model 301 gas chromatograph (MTE \#IW-0113) calibrated prior to use with Scotty ${ }^{\circledR}$ II gas standards containing 10 and $100 \mathrm{ppm}$ benzene in air. The flow rate of the nitrogen purge gas was checked immediately before and after sampling using two bubble flowmeters. One flowmeter upstream of the gas sampling location measured flow entering the glass reactor. The other flowmeter measured flow downstream of the sampling location. The gas was not sampled unless the measured flowrates for both flowmeter agreed, indicating no leaks in the system. On a few occasions, liquid was drawn into syringe during sampling. Sampling was then halted until the line heater was turned on for a minimum of 2 hours after which no liquid was found during sampling. Slurry samples were periodically taken from test vessel and prepared for radiochemical and chemical analyses as previously reported.

\section{Test 2U}

Simulant tests conducted concurrently with the onset of the radioactive tests indicated that benzene was a necessary component to produce a rapid NaTPB decomposition reaction[5]. With continuous stirring and purging of the reactor vessel, benzene concentrations in the precipitate slurry would be kept low. Therefore, on June 25, 1997, the nitrogen purge and continuous agitation were stopped to allow accumulation of benzene and determine if higher benzene generation rates developed. The temperature of the precipitate slurry was maintained at $45^{\circ} \mathrm{C}$. The period of time when the slurry was not agitated and purged is identified as Test 2U. A single liquid sample taken on July 28, 1997, was analyzed for chemical and radiochemical composition. On August 13, 1997, Test $2 U$ concluded when the water bath heater was shut off and the temperature of the radioactive slurry allowed to fall to the ambient Cell 10 temperature (ca. $25^{\circ} \mathrm{C}$ ).

\section{Tests $2 \mathrm{~A}$}

The purpose of this test was to determine the effect of higher temperature on the NaTPB decomposition rate. A portion of the slurry was removed from the reactor on June 26, 1997, placed in a separate glass vessel, purged with nitrogen, stoppered and heated to $55^{\circ} \mathrm{C}$ in an oven until July 24,1997 . This test is referred to as Test $2 \mathrm{~A}$.

\section{Test 2B}

Test 2B used a 100-mL aliquot of the Batch 2 slurry removed from the glass reactor on August 12, 1997 and placed in a carbon steel vessel. NaTPB solution (7.061 g, Holly Oak) was added to the vessel on August 13, 1997. The vessel was sealed under an air atmosphere and placed in an Fisher Scientific Isotemp ${ }^{\circledR}$ gravity convection oven, Model 500 Series heated to $45^{\circ} \mathrm{C}$. For the first 4.5 hours, the oven temperature ranged from 32 to $52{ }^{\circ} \mathrm{C}$ until stabilizing at $50 \pm 1{ }^{\circ} \mathrm{C}$ for the next 12 hours. The temperature setting was lowered and stabilized around $46^{\circ} \mathrm{C}$. From August 14, 1997 until September 25, 1997 the oven temperature ranged from 41 to $49^{\circ} \mathrm{C}$.

On August 19, 1997, solid NaTPB (1.572 g, Aquafine Batch \# CT22-911218, Drum \# 17971870 , Sample \# AQA22) was added to the vessel. Slurry samples were taken periodically using a 10-mL syringe. The vessel was swirled immediately after adding NaTPB and prior to 
each sampling. Slurry samples were filtered and analyzed as described previously in the Batch 2 Test. The test concluded on September 25, 1997.

\section{Test 2C}

A 100-mL aliquot of the Batch 2 slurry was removed from the glass reactor on August 12, 1997 and placed in a carbon steel vessel. NaTPB solution (7.071 g, Holly Oak) was added to the vessel on August 13, 1997. The vessel was sealed under an air atmosphere and placed in the oven (Fisher Isotemp ${ }^{8}$ ). Test $2 \mathrm{C}$ experienced the same temperature profile as reported in Test 2B. On September 9, 1997, solid NaTPB (1.639 g, Aquafine) was added to the vessel. Slurry samples were taken periodically using a $10-\mathrm{mL}$ syringe. The vessel was swirled immediately after adding NaTPB and prior to each sampling. Slurry samples were filtered and analyzed as described previously. The test concluded on September 25, 1997.

\section{Test 3A}

Slurry from Test $2 \mathrm{~B}(16.2 \mathrm{~mL})$ combined with Tank $32 \mathrm{H}(43.7 \mathrm{~mL})$, Tank $34 \mathrm{~F} / 39 \mathrm{H}$ composite $(30.3 \mathrm{~mL})$, inhibited water $(20.3 \mathrm{~mL})$ and Tank $11 \mathrm{H}$ sludge $(0.065 \mathrm{~g})$ in a clean carbon steel vessel on September 29, 1997. NaTPB solution ( $3.230 \mathrm{~g}$, Holly Oak) and monosodium titanate slurry ( 3 drops, Optima Chemicals, Inc., Batch \#95QAB451) were added to the vessel on September 30, 1997. The vessel was sealed under an air atmosphere and placed in the oven (Fisher Isotemp ${ }^{\circledR}$ ) maintained at $45 \pm 5^{\circ} \mathrm{C}$ on October 1,1997 . On October 23, 1997, NaTPB solution (2.025 g, Holly Oak) was added to the vessel. Slurry samples were taken periodically using a $10-\mathrm{mL}$ syringe. The vessel was swirled immediately after adding NaTPB and prior to each sampling. Slurry samples were filtered and analyzed as described previously. The test concluded on November 24, 1997.

\section{Test 3B}

Slurry from Test 2B $(2.3 \mathrm{~mL})$ was combined with Tank $32 \mathrm{H}(41.2 \mathrm{~mL})$, Tank $34 \mathrm{~F} / 39 \mathrm{H}$ composite $(39.4 \mathrm{~mL})$, inhibited water $(24.6 \mathrm{~mL})$ and Tank $11 \mathrm{H}$ sludge $(0.074 \mathrm{~g})$ in a clean carbon steel vessel on September 29, 1997. NaTPB solution (3.896 g, Holly Oak) and monosodium titanate slurry ( 3 drops, Optima Chemicals, Inc., Batch \#95QAB451) were added to the vessel on September 30, 1997. The vessel was sealed under an air atmosphere and placed in the oven (Fisher Isotemp ${ }^{(8)}$ ) maintained at $45 \pm 5^{\circ} \mathrm{C}$ on October 1,1997 . On October 23, 1997, NaTPB solution (1.233 g, Holly Oak) was added to the vessel. Slurry samples were taken periodically using a $10-\mathrm{mL}$ syringe. The vessel was swirled immediately after adding NaTPB and prior to each sampling. Slurry samples were filtered and analyzed as described previously. The test concluded on November 10, 1997.

\section{Test 3C}

Slurry from Batch $2(16.4 \mathrm{~mL})$ combined with Tank $32 \mathrm{H}(42.8 \mathrm{~mL})$, Tank $34 \mathrm{~F} / 39 \mathrm{H}$ composite $(29.8 \mathrm{~mL})$, inhibited water $(19.8 \mathrm{~mL})$ and Tank $11 \mathrm{H}$ sludge $(0.066 \mathrm{~g})$ in a clean carbon steel vessel on September 29, 1997. NaTPB solution (3.345 g, Holly Oak) and monosodium titanate slurry ( 3 drops, Optima Chemicals, Inc., Batch \#95QAB451) were added to the vessel on October 1,1997 . The vessel was sealed under an air atmosphere and in the oven (Fisher Isotemp ${ }^{8}$ ) maintained at $45 \pm 5^{\circ} \mathrm{C}$. On October $23,1997, \mathrm{NaTPB}$ solution $(0.423 \mathrm{~g}$, Holly Oak) was added to the vessel. Slurry samples were taken periodically using a $10-\mathrm{mL}$ syringe. The vessel was swirled immediately after adding NaTPB and prior to each 
sampling. Slurry samples were filtered and analyzed as described previously in the Batch 2 Test. The test concluded on November 24, 1997.

\section{Test 3D}

Slurry from Batch $2(2.8 \mathrm{~mL})$ combined with Tank $32 \mathrm{H}(42.1 \mathrm{~mL})$, Tank $34 \mathrm{~F} / 39 \mathrm{H}$ composite $(39.6 \mathrm{~mL})$, inhibited water $(25.2 \mathrm{~mL})$ and Tank $11 \mathrm{H}$ sludge $(0.075 \mathrm{~g})$ in a clean carbon steel vessel on September 29, 1997. NaTPB solution ( $3.803 \mathrm{~g}$, Holly Oak) and monosodium titanate slurry ( 3 drops, Optima Chemicals, Inc., Batch \#95QAB451)were added to the vessel on September 30, 1997. The vessel was sealed under an air atmosphere and placed in the oven (Fisher Isotemp ${ }^{\circledR}$ ) maintained at $45 \pm 5^{\circ} \mathrm{C}$ on October 1, 1997. On October 23, 1997, NaTPB solution ( $1.440 \mathrm{~g}$, Holly Oak) was added to the vessel. Slurry samples were taken periodically using a $10-\mathrm{mL}$ syringe. The vessel was swirled immediately after adding NaTPB and prior to each sampling. Slurry samples were filtered and analyzed as described previously. The test concluded on December 15, 1997.

\section{Test 2.7}

Slurry from Test $2 \mathrm{~B}(16 \mathrm{~mL})$ and Test $2 \mathrm{C}(22 \mathrm{~mL})$ was combined with inhibited water $(23$ $\mathrm{mL})$ in a clean carbon steel vessel on September 29,1997 . NaTPB solution $(0.485 \mathrm{~g}$, Holly Oak) was added to the vessel on September 30,1997. The vessel was sealed under an air atmosphere and placed in the oven (Fisher Isotemp ${ }^{\circledR}$ ) maintained at $45 \pm 5^{\circ} \mathrm{C}$ on October 1 , 1997. Slurry samples were taken periodically using a $10-\mathrm{mL}$ syringe. The vessel was swirled immediately after adding NaTPB and prior to each sampling. Slurry samples were filtered and analyzed as described previously. The test concluded on November 10, 1997.

\section{Test 4A}

Slurry from Test $3 \mathrm{~A}(19.4 \mathrm{~mL})$ was combined with Tank $32 \mathrm{H}(34.2 \mathrm{~mL})$, Tank $34 \mathrm{~F} / 39 \mathrm{H}$ composite $(35.3 \mathrm{~mL})$, and inhibited water $(21.4 \mathrm{~mL})$ in a clean carbon steel vessel on November 24,1997 . Monosodium titanate slurry ( 3 drops), Tank $11 \mathrm{H}$ sludge $(0.026 \mathrm{~g})$ and NaTPB solution (5.419 g, Holly Oak) were added to the vessel on December 2, 1997. The vessel was sealed under an air atmosphere and placed in the oven (Fisher Isotemp ${ }^{\circledR}$ ) maintained at $45 \pm 4{ }^{\circ} \mathrm{C}$ on December 2,1997 . Slurry samples were taken periodically using a 10-mL syringe. The vessel was swirled immediately after adding NaTPB and prior to each sampling. Slurry samples were filtered and analyzed as described previously. The test concluded on January 8, 1998.

\section{Test 4C}

Slurry from Test $3 \mathrm{C}(16.6 \mathrm{~mL})$ was combined with Tank $32 \mathrm{H}(27.0 \mathrm{~mL})$, Tank $34 \mathrm{~F} / 39 \mathrm{H}$ composite $(27.1 \mathrm{~mL})$, and inhibited water $(16.4 \mathrm{~mL})$ in a clean carbon steel vessel on November 24,1997 . Monosodium titanate slurry (2 drops), Tank $11 \mathrm{H}$ sludge $(0.026 \mathrm{~g})$ and NaTPB solution $(5.419 \mathrm{~g}$, Holly Oak) were added to the vessel on December 2, 1997. The vessel was sealed under an air atmosphere and placed in the oven (Fisher Isotemp ${ }^{(1)}$ ) maintained at $45 \pm 4{ }^{\circ} \mathrm{C}$ on December 2,1997 . Slurry samples were taken periodically using a $10-\mathrm{mL}$ syringe. The vessel was swirled immediately after adding NaTPB and prior to each sampling. Slurry samples were filtered and analyzed as described previously. The first two samples taken from the Test $4 \mathrm{C}$ vessel had a high Cs-137 content. It was believed that an error had been made during the first NaTPB addition. Therefore, a second addition of 
NaTPB solution ( $3.950 \mathrm{~g}$, Holly Oak) was made to the vessel on December 12, 1997. The test concluded on January 19, 1998. From January 15 to January 19, 1998, the temperature cycle of the oven changed such that the temperature reached a minimum of $39.5^{\circ} \mathrm{C}$ during the cycle.

\subsection{Results and Discussion}

Table II gives a summary of selected conditions for each test. Waste materials used in the tests came from Tanks $48 \mathrm{H}, 49 \mathrm{H}$, Tank $25 \mathrm{~F}, 32 \mathrm{H}, 34 \mathrm{~F}$ and $39 \mathrm{H}$. Sludge samples from Tanks $4 \mathrm{~F}$ and $11 \mathrm{H}$ archived at SRTC were also used to increase the insoluble solids to a target concentration of about $1000 \mathrm{mg} / \mathrm{L}$ on a fresh waste supernatant liquid basis. Table II also contains the average 'NaTPB Demand' concentration determined for each filter test batch, NaTPB addition times and the calculated mole ratio of NaTPB to TPB demand.

Table III provides sludge concentrations and estimated internal dose rates based on Cs-137 activities. The calculated internal dose rates are higher than actual rates since the calculations assume no loss of decay energy. Because of the small size of the test vessels, approximately $30 \%$ of the gamma energy would escape. Thus, the internal dose rates would be approximately $70 \%$ of the values indicated in Table III.

External dose rates measured within Cell 11 of the Shielded Cells Facility ranged from 1 to $20 \mathrm{rad} / \mathrm{h}$ (see Appendix 9.12). Internal dose rates based on the measured Cs-137 activity for the radioactive tests ranged from 591 to $1040 \mathrm{rad} / \mathrm{h}$. Thus, the observed decomposition rates in the radioactive tests cannot be attributed to a high external dose rate within the Shielded Cells facility. 
Table II. Selected Test Conditions

\begin{tabular}{|c|c|c|c|c|c|c|}
\hline $\begin{array}{l}\text { Test ID } \\
\text { (Temp) }\end{array}$ & $\begin{array}{c}\text { Waste } \\
\text { Makeup }\end{array}$ & $\begin{array}{c}\text { Volume } \\
\text { (mL) }\end{array}$ & $\begin{array}{c}\text { TPB } \\
\text { Demand } \\
\text { (M) }\end{array}$ & & $\begin{array}{l}\text { Time of } \\
\text { Addition } \\
\text { (hours) }\end{array}$ & $\begin{array}{c}\text { mole ratio } \\
\text { NaTPB: } \\
\text { TPB Demand }\end{array}$ \\
\hline $\begin{array}{l}\text { Batch } 2 \\
\left(45^{\circ} \mathrm{C}\right)\end{array}$ & $\begin{array}{c}48 \mathrm{H} \\
49 \mathrm{H} \\
25 \mathrm{~F} \\
\mathrm{IW}\end{array}$ & $\begin{array}{l}106 \\
140 \\
170 \\
117\end{array}$ & 0.032 & $\begin{array}{l}\text { 1st addn. } \\
\text { 2nd addn. }\end{array}$ & $\begin{array}{c}0 \\
426\end{array}$ & $\begin{array}{l}1.32 \\
1.41\end{array}$ \\
\hline $2 \mathrm{U}$ & Batch 2 & - & $\mathrm{dnm}$ & none & $\mathrm{n} / \mathrm{a}$ & 1.41 \\
\hline $\begin{array}{c}2 \mathrm{~A} \\
\left(55^{\circ} \mathrm{C}\right)\end{array}$ & Batch 2 & 30.0 & $\mathrm{dnm}$ & none & $\bar{n} / \mathbf{a}$ & 1.41 \\
\hline $\begin{array}{c}2 \mathrm{~B} \\
\left(45^{\circ} \mathrm{C}\right)\end{array}$ & Batch 2 & 100 & dnm & $\begin{array}{l}\text { 1st addn. } \\
\text { 2nd addn. }\end{array}$ & $\begin{array}{c}0 \\
151\end{array}$ & $\begin{array}{l}2.61 \\
3.81\end{array}$ \\
\hline $\begin{array}{c}2 \mathrm{C} \\
\left(45^{\circ} \mathrm{C}\right)\end{array}$ & Batch 2 & 100 & $\mathrm{dnm}$ & $\begin{array}{l}\text { 1st addn. } \\
\text { 2nd addn. }\end{array}$ & $\begin{array}{c}0 \\
648\end{array}$ & $\begin{array}{l}2.61 \\
3.81\end{array}$ \\
\hline $\begin{array}{c}3 \mathrm{~A} \\
\left(45^{\circ} \mathrm{C}\right)\end{array}$ & $\begin{array}{c}\text { Batch 2B } \\
32 \mathrm{H} \\
34 \mathrm{~F} / 39 \mathrm{H} \\
\text { IW }\end{array}$ & $\begin{array}{l}16.2 \\
43.7 \\
30.3 \\
20.3\end{array}$ & 0.026 & $\begin{array}{l}\text { 1st addn. } \\
\text { 2nd addn. }\end{array}$ & $\begin{array}{c}0 \\
528\end{array}$ & $\begin{array}{l}0.65 \\
1.08\end{array}$ \\
\hline $\begin{array}{c}3 \mathrm{~B} \\
\left(45^{\circ} \mathrm{C}\right)\end{array}$ & $\begin{array}{c}\text { Batch } 2 \mathrm{C} \\
32 \mathrm{H} \\
34 \mathrm{~F} / 39 \mathrm{H} \\
\text { IW }\end{array}$ & \begin{tabular}{c|}
2.3 \\
41.2 \\
39.4 \\
24.6
\end{tabular} & 0.025 & $\begin{array}{l}\text { 1st addn. } \\
\text { 2nd addn. }\end{array}$ & $\begin{array}{c}0 \\
528\end{array}$ & $\begin{array}{l}0.84 \\
1.10\end{array}$ \\
\hline $\begin{array}{c}3 \mathrm{C} \\
\left(45^{\circ} \mathrm{C}\right)\end{array}$ & $\begin{array}{c}\text { Batch } 2 \\
32 \mathrm{H} \\
34 \mathrm{~F} / 39 \mathrm{H} \\
\text { IW }\end{array}$ & \begin{tabular}{l|}
16.4 \\
42.8 \\
29.8 \\
19.8
\end{tabular} & 0.089 & $\begin{array}{l}\text { 1st addn. } \\
\text { 2nd addn. }\end{array}$ & $\begin{array}{c}0 \\
528\end{array}$ & $\begin{array}{l}0.69 \\
0.78\end{array}$ \\
\hline $\begin{array}{c}3 \mathrm{D} \\
\left(45^{\circ} \mathrm{C}\right)\end{array}$ & $\begin{array}{c}\text { Batch } 2 \\
32 \mathrm{H} \\
34 \mathrm{~F} / 39 \mathrm{H} \\
\text { IW }\end{array}$ & $\begin{array}{l}2.8 \\
42.1 \\
39.6 \\
25.2\end{array}$ & 0.025 & $\begin{array}{l}\text { 1st addn. } \\
\text { 2nd addn. }\end{array}$ & $\begin{array}{c}0 \\
528\end{array}$ & $\begin{array}{l}0.80 \\
1.11\end{array}$ \\
\hline $\begin{array}{c}2.7 \\
\left(45^{\circ} \mathrm{C}\right)\end{array}$ & $\begin{array}{l}\text { Batch 2B } \\
\text { Batch 2C } \\
\text { IW }\end{array}$ & $\begin{array}{l}16.0 \\
22.0 \\
23.0\end{array}$ & dnm & Ist addn. & 0 & \\
\hline $\begin{array}{c}4 \mathrm{~A} \\
\left(45^{\circ} \mathrm{C}\right)\end{array}$ & $\begin{array}{c}\text { Batch } 3 \mathrm{~A} \\
32 \mathrm{H} \\
34 \mathrm{~F} / 39 \mathrm{H} \\
\text { IW }\end{array}$ & $\begin{array}{l}19.4 \\
34.2 \\
35.3 \\
21.4\end{array}$ & 0.020 & 1st addn. & $\overline{0}$ & 1.53 \\
\hline $\begin{array}{c}4 \mathrm{C} \\
\left(45^{\circ} \mathrm{C}\right)\end{array}$ & $\begin{array}{c}\text { Batch 3C } \\
32 \mathrm{H} \\
34 \mathrm{~F} / 39 \mathrm{H} \\
\text { IW }\end{array}$ & $\begin{array}{l}16.6 \\
27.0 \\
27.1 \\
16.4 \\
\end{array}$ & 0.024 & $\begin{array}{l}\text { 1st addn. } \\
2 \text { nd addn. }\end{array}$ & $\begin{array}{c}0 \\
236\end{array}$ & $\begin{array}{l}1.41 \\
2.65\end{array}$ \\
\hline
\end{tabular}


Table III. Sludge Concentrations and Internal Dose Rates

\begin{tabular}{ccccc} 
Test ID & $\begin{array}{c}\text { Sludge Conc. } \\
\text { in Supernate } \\
(\mathbf{m g} / \mathbf{L})\end{array}$ & $\begin{array}{c}\text { Sludge Conc. } \\
\text { in Test Slurry } \\
(\mathbf{m g} / \mathbf{L})\end{array}$ & $\begin{array}{c}\text { Total } \\
\mathbf{C s}-137 \\
(\mathbf{n C i} / \mathbf{g})\end{array}$ & $\begin{array}{c}\text { Internal } \\
\text { Dose Rate } \\
(\mathbf{r a d} / \mathbf{h})\end{array}$ \\
\hline $\begin{array}{c}\text { Batch 2 } \\
\text { (includes 2U, 2A, 2B, 2C) }\end{array}$ & 170 & 1380 & $5.75 \mathrm{E}+05$ & 1000 \\
3A & $1350(95)$ & $1060(61)$ & $5.99 \mathrm{E}+05$ & 1040 \\
3B & $1460(107)$ & $1110(80)$ & $5.91 \mathrm{E}+05$ & 1030 \\
3C & $1380(96)$ & $1130(64)$ & $5.99 \mathrm{E}+05$ & 1040 \\
3D & $1450(108)$ & $1120(81)$ & $5.90 \mathrm{E}+05$ & 1030 \\
2.7 & - & 860 & $3.40 \mathrm{E}+05$ & 591 \\
4A & $930(112)$ & $780(82)$ & $5.91 \mathrm{E}+05$ & 1030 \\
4C & $920(111)$ & $790(82)$ & $.5 .93 \mathrm{E}+05$ & 1030
\end{tabular}

Supernate sludge concentration is the concentration of sludge solids in fresh waste supernate added to test makeup (i.e., excludes Tank $48 \mathrm{H}$ heel, inhibited water and added NaTPB solution). Test slurry sludge concentration is the concentration of sludge solids in the final test slurry excluding added NaTPB solution. Numbers in parenthesis are the single standard deviations.

Tables IV and V present a summary of the benzene generation rates determined in the radioactive tests, reflecting results with and without excess NaTPB present. For the Batch 2 rates determined from gas measurements, the minimum and maximum values equal the average value \pm 2 standard deviations. The average values from soluble boron data are determined from the slope of the linear equation from fitting the concentration versus time data. The minimum and maximum values are the lower and upper $95 \%$ confidence intervals about the average. Where noted rates have been corrected for changes in intermediate concentrations at the beginning and end of the test.

Analytical results for the filtrate samples taken during each test are provided in Appendices 9.13 (Batch 2 and Tests 2U, 2A, 2B and 2C), 9.14 (Tests 3A, 3B, 3C and 3D) and 9.15 (Tests $4 \mathrm{~A}, 4 \mathrm{C}$ and 2.7). Included in the data tables are the concentrations of $\mathrm{Cs}-137$, total alpha, potassium, boron, NaTPB, 3PB, $2 \mathrm{~PB}, 1 \mathrm{~PB}$ and phenol. 


\section{Table IV. Benzene Generation Rates and Induction Times in Radioactive Tests with Excess NaTPB Present}

\begin{tabular}{|c|c|c|c|c|}
\hline \multirow[b]{2}{*}{ Test ID } & \multicolumn{3}{|c|}{ Benzene Generation Rate (mg/L-h) } & \multirow{2}{*}{$\begin{array}{c}\text { Induction } \\
\text { Time }(\mathbf{h})^{b}\end{array}$} \\
\hline & $\underline{\text { Minimum }}$ & Average & Maximum & \\
\hline Batch 2 & $0.023^{c}$ & $0.065^{c}$ & $0.11^{c}$ & \\
\hline Batch 2 & 0.0 & 1.4 & 6.8 & $590<x<1285$ \\
\hline $2 \mathrm{U}$ & & & 1.5 & \\
\hline $2 \mathrm{~A}$ & $5.3^{\mathrm{d}}$ & $7.0^{\mathrm{d}}$ & $7.2^{d}$ & $0<x<566$ \\
\hline 2B & 18 & 29 & 39 & $186<x<305$ \\
\hline $2 \mathrm{C}$ & 4.9 & 10 & 16 & $375<x<474$ \\
\hline 2.7 & & 20 & & $0<x<141$ \\
\hline $3 \mathrm{~A}$ & & $7.8^{\mathrm{e}}$ & & $<90^{\text {f }}$ \\
\hline $3 \mathrm{~B}$ & 3.4 & 5.5 & 7.7 & $<90^{\mathrm{f}}$ to $<290^{\mathrm{b}}$ \\
\hline $3 \mathrm{C}$ & & $7.8^{\mathrm{e}}$ & & $<90^{\mathrm{f}}$ \\
\hline 3D & 1.7 & 3.0 & 4.3 & $<90^{\mathrm{f}}$ to $<976^{\mathrm{b}}$ \\
\hline $4 \mathrm{~A}$ & & $15^{\mathrm{g}}$ & & $18<x<185$ \\
\hline $4 \mathrm{C}$ & 0 & 5.2 & 11 & $472<x<666$ \\
\hline \multicolumn{5}{|c|}{ a Except as noted, the benzene generation rates were determined from soluble boron measurements } \\
\hline \multicolumn{5}{|c|}{$\begin{array}{l}\text { assuming four moles of benzene produced per mole of soluble boron and correcting for generation or } \\
\text { loss of intermediates at the beginning and end of the test. Minimum and maximum values are the lower } \\
\text { and upper } 95 \% \text { confidence limits about the linear fit of the data. }\end{array}$} \\
\hline \multirow{3}{*}{\multicolumn{5}{|c|}{$\begin{array}{l}\text { Induction time is the time from the start of the test until a sharp rise occurred in the concentrations of } \\
\text { intermediates (3PB, 2PB, 1PB) or soluble boron. } \\
\text { d Determined by direct gas measurements. } \\
\text { Based on calculated residual excess NaTPB at start of test from Batch } 2 \text { and time until loss of Cs-137 DF. Cs-137 } \\
\text { DF loss defined as Cs-137 activity }>30 \mathrm{nCi} / \mathrm{g} \text {. }\end{array}$}} \\
\hline & & & & \\
\hline & & & & \\
\hline \multicolumn{5}{|c|}{ Based on the time between addition of an excess of NaTPB and loss of Cs-137 DF. } \\
\hline \multicolumn{5}{|c|}{$\begin{array}{l}\text { Estimated from the time of the second NaTPB addition to the next sample which exhibited loss of NaTPB or } \\
\text { formation of intermediates. }\end{array}$} \\
\hline \multicolumn{5}{|c|}{$\begin{array}{l}\text { Based on soluble boron and intermediates measurements in the interval between } 185 \text { and } 308 \text { hours } \\
\text { assuming four moles of benzene produced per mole of soluble boron and correcting for generation or } \\
\text { loss of intermediates. }\end{array}$} \\
\hline
\end{tabular}

\section{Table V. Benzene Generation Rates in Radioactive Tests in the Absence of Excess NaTPB}

\begin{tabular}{|c|c|c|c|}
\hline & \multicolumn{3}{|c|}{ Benzene Generation Rate (mg/L-h) ${ }^{a}$} \\
\hline Test ID & Minimum & Average & Maximu \\
\hline $3 \mathrm{~A}$ & 1.6 & 2.5 & 3.4 \\
\hline $3 \mathrm{C}$ & 3.5 & 4.0 & 4. \\
\hline $4 \mathrm{~A}$ & 1.1 & 1.8 & 2.5 \\
\hline
\end{tabular}

a Determined from linear fit of cesium-137 data with time assuming cesium-137 to potassium ratio of $60 \mathrm{nCi} / \mathrm{g}$, 4 moles of benzene produced per mole $\mathrm{K}$ produced with no correction for formation of intermediates.

Sodium, hydroxide, nitrate and nitrite concentrations for each radioactive test are shown in Table VI. These concentrations are based on measured values for each of the individual test components (see Appendices 9.1 - 9.6). Two values are provided; before addition of any $\mathrm{NaTPB}$ and after the last addition of NaTPB. Note that the 
concentrations of hydroxide, nitrate and nitrite were significantly different in Batch 2 compared to the Batches 3 and 4 tests.

Table VI. Sodium, Hydroxide, Nitrate and Nitrite Concentrations in Radioactive Tests

\begin{tabular}{|c|c|c|c|c|c|}
\hline \multirow[b]{2}{*}{ Tests ID } & \multirow{2}{*}{$\begin{array}{l}\text { NaTPB } \\
\text { Addition }\end{array}$} & \multicolumn{4}{|c|}{ Concentration (M) } \\
\hline & & Sodium & $\underline{\text { Hydroxide }}$ & Nitrate & Nitrite \\
\hline \multirow[t]{2}{*}{ Batch 2} & before & 4.8 & 2.8 & 0.62 & 0.71 \\
\hline & after & 4.5 & 2.6 & 0.58 & 0.66 \\
\hline \multirow[t]{2}{*}{ Batch 2B } & before & 4.5 & 2.6 & 0.58 & 0.66 \\
\hline & after & 4.3 & 2.4 & 0.54 & 0.62 \\
\hline \multirow[t]{2}{*}{ Batch 2C } & before & 4.5 & 2.6 & 0.58 & 0.66 \\
\hline & after & 4.3 & 2.4 & 0.54 & 0.62 \\
\hline \multirow[t]{2}{*}{ Test 2.7} & before & 2.7 & 1.5 & 0.34 & 0.39 \\
\hline & after & 2.7 & 1.5 & 0.34 & 0.39 \\
\hline \multirow[t]{2}{*}{ Test 3A } & before & 5.0 & 2.2 & 1.6 & 0.76 \\
\hline & after & 4.8 & 2.1 & 1.5 & 0.72 \\
\hline \multirow[t]{2}{*}{ Test 3B } & before & 5.2 & 2.3 & 1.7 & 0.74 \\
\hline & after & 5.0 & 2.2 & 1.6 & 0.70 \\
\hline \multirow[t]{2}{*}{ Test 3C } & before & 5.0 & 2.3 & 1.6 & 0.76 \\
\hline & after & 4.9 & 2.2 & 1.5 & 0.73 \\
\hline \multirow[t]{2}{*}{ Test 3D } & before & 5.2 & 2.3 & 1.7 & 0.74 \\
\hline & after & 5.0 & 2.2 & 1.6 & 0.70 \\
\hline \multirow[t]{2}{*}{ Test 4A } & before & 5.2 & 2.2 & 1.7 & 0.73 \\
\hline & after & 5.0 & 2.1 & 1.6 & 0.69 \\
\hline \multirow[t]{2}{*}{ Test $4 \mathrm{C}$} & before & 5.2 & 2.2 & 1.7 & 0.74 \\
\hline & after & 4.8 & 2.0 & 1.5 & 0.67 \\
\hline
\end{tabular}

General Findings

Cesium-137 removal was successfully demonstrated in these radioactive tests at low molar excess of NaTPB. The concentration of soluble NaTPB was lower in the radioactive tests than expected from previously reported data at the high liquid phase ionic strength[18]. Additions of NaTPB after the precipitation of cesium and potassium did not increase the solution concentration of NaTPB significantly. 
Benzene generation rates in the presence of excess NaTPB higher than $7 \mathrm{mg} / \mathrm{L}-\mathrm{hr}$ were observed in 7 of the 12 tests. Benzene generation rates from the decomposition of Cs/KTPB solids measured in 3 tests at less than $4.5 \mathrm{mg} / \mathrm{L}-\mathrm{hr}$. Variations in the measured rates could not be attributed to variations in slurry makeup (e.g., waste tank, sludge solids content or major salt species concentrations), addition of large NaTPB excess, source of NaTPB, carryover of a heel from one test to another, or internal or external dose rates. Thus, variations in decomposition rates and induction times are attributed to uncontrolled parameters.

Although similar rate of NaTPB decomposition were observed in both simulant tests and radioactive tests, significant differences exist between the concentrations of metals present in the radioactive tests and the metals in the ECC sludge composition used in simulant tests[24] (see Appendices 9.9, 9.10, 9.11 and 9.12) for a comparison of metals concenrations in the $\mathrm{ECC}$ and radioactive tests). For example, the concentrations of $\mathrm{Ag}, \mathrm{Fe}, \mathrm{Hg}, \mathrm{Mn}, \mathrm{Ni}, \mathrm{Pd}, \mathrm{Ti}$ and $\mathrm{Zr}$ in the radioactive tests ranged from 2 to 250 times lower than in the ECC sludge simulant tests. However, the concentrations of other metals such as $\mathrm{As}, \mathrm{Ca}, \mathrm{Cd}, \mathrm{Ce}, \mathrm{Co}, \mathrm{Cu}$, $\mathrm{La}, \mathrm{Mo}, \mathrm{Se}$, and $\mathrm{Sr}$ ranged from 2 to 160 times higher than the ECC concentrations. Low levels $(0.7 \mu \mathrm{g} / \mathrm{L}$ to $1.1 \mathrm{mg} / \mathrm{L})$ of V, Tc, W, Re, Os, Ir , Pt and Au were also detected in some of the radioactive waste materials. These metals are not added as a part of the ECC sludge matrix. Platinum has been reported to catalyze the chemical decomposition of NaTPB ${ }^{1}$. The catalytic activity of the other metals is not known. With the exception of $V$ and $T c$, these metals are not fission products. Values at the $1 \mu \mathrm{g} / \mathrm{L}$ level are at the detection limits of the analytical method (ICP-MS). Since these metals are not fission products and are present at or near the lower detection limit, their presence and possible catalytic activity are highly uncertain and may warrant further investigation.

\section{Batch 2}

Monosodium titanate slurry was not added to Batch 2 since the calculated Sr-90 and total alpha activity of the feed slurry was below the Saltstone feed limits of 40 and $18 \mathrm{nCi} / \mathrm{g}$, respectively[15]. Acceptably low $\mathrm{Sr}-90(7.9 \pm 1.9 \mathrm{nCi} / \mathrm{g})$ and total alpha $(0.83 \mathrm{nCi} / \mathrm{g})$ activities in the liquid phase was confirmed in the first sample taken 13.7 hours after addition of NaTPB. Cesium-137 decontamination $(\leq 30 \mathrm{nCi} / \mathrm{g})$ was achieved about 11 days after the addition of NaTPB.

The concentration of NaTPB in the liquid phase initially fell below the detection limit for the HPLC method $(<10 \mathrm{mg} / \mathrm{L})$. About the time cesium precipitation completed, the NaTPB concentration rose slightly above the detection limit and stayed at or below $41 \mathrm{mg} / \mathrm{L}$ during the remainder of the test. A second addition of NaTPB, after precipitation of all of the cesium and potassium, failed to significantly increase the NaTPB concentration in filtrates from slurry samples.

The predicted solubility $(\geq 500 \mathrm{mg} / \mathrm{L})$ of NaTPB at the sodium ion concentration of Batch 2 $(4.5 \mathrm{M})$ greatly exceeds the measured values during this test $[18,19]$. The mole percent excess of NaTPB after the first addition of NaTPB is $32 \%$ (i.e., total soluble and insoluble concentration of $3500 \mathrm{mg} / \mathrm{L}$ ). Although a second addition of NaTPB raised the excess to 41

\footnotetext{
1 Preliminary results reported by Y. Su (PNNL) from work funded by DOE EMSP Basic Sciences grant.
} 
mole $\%$ ( $4500 \mathrm{mg} / \mathrm{L})$, the liquid phase concentration of NaTPB still did not increase significantly. Results from recent tests indicate the solubility of NaTPB in the absence of potassium is lower than previously reported and the presence of potassium further decreases the apparent solubility of NaTPB [20].

The 3PB concentration also increased about the time cesium precipitation completed. The increase is not attributed to decomposition of NaTPB since the concentrations of $2 \mathrm{~PB}$ and $1 \mathrm{~PB}$ did not show a rise. Cesium has been reported to be precipitated as a 3PB adduct[21]. The observed rise in the $3 \mathrm{~PB}$ concentration may be due to the release of $3 \mathrm{~PB}$ initially precipitated as the Cs.3PB adduct. Based on the 3PB concentration in the NaTPB solution added to the test slurry, the initial 3 PB concentration should have been about $480 \mathrm{mg} / \mathrm{L}$ compared to measured values of between 69 and $77 \mathrm{mg} / \mathrm{L}$. Thus, a portion of cesium apparently precipitated as the $3 \mathrm{~PB}$ adduct, which then converted to the more stable CsTPB salt, releasing $3 \mathrm{~PB}$ to dissolve into solution.

Benzene generation rates determined from gas phase measurements ranged from a low of 0.021 to a high of $0.11 \mathrm{mg} / \mathrm{L}-\mathrm{h}$ for Batch 2 with an average of $0.065 \pm 0.021 \mathrm{mg} / \mathrm{L}-\mathrm{h}$. (see Table VII). There was no discernible systematic trends in the benzene rates over the course of the test. The observed generation rate is consistent with that previously reported for waste slurries due to radiolytic and thermal decomposition[22]. For example, a benzene generation rate of $0.02 \mathrm{mg} / \mathrm{L}-\mathrm{h}$ is predicted for a radioactive slurry at $4.5 \mathrm{M}$ sodium ion concentration and dose rate of $1000 \mathrm{rad} / \mathrm{h}[22]$. These results suggest that the measured benzene generation rate is due to radiolytic and thermal decomposition and not to a catalytic reaction.

To confirm the low benzene generation rate at the low dissolved NaTPB concentration, the total soluble boron concentration in the filtered liquid phase was determined three separate times over the course of the test. Figure 3 shows a plot of the total soluble boron and phenol concentrations with time for Batch 2. Soluble boron and phenol concentrations for samples taken in Tests $2 \mathrm{U}$ and $2 \mathrm{~A}$ are also included. The boron concentrations are corrected for boron leached from the borosilicate glass vessel (see Appendix 9.16 for details on the boron leaching rates). 
Table VII. Benzene Generation Rates in Batch 2 Determined from Gas Measurements

\begin{tabular}{|c|c|c|c|}
\hline $\begin{array}{c}\text { Time } \\
\text { (h) }\end{array}$ & $\begin{array}{c}\text { Incremental } \\
\text { Bz Gen. Rate } \\
(\mu \mathrm{g} / \mathrm{L}-\mathrm{hr})\end{array}$ & $\begin{array}{c}\text { Cumulative } \\
\text { Bz Gen. Rate } \\
(\mu \mathrm{g} / \mathrm{L}-\mathrm{hr})\end{array}$ & $\begin{array}{c}\text { Std. Dev. } \\
\text { Bz Gen. Rate } \\
(\mu \mathrm{g} / \mathrm{L}-\mathrm{hr})\end{array}$ \\
\hline 13 & 61 & 61 & \\
\hline 63 & 56 & 59 & 4 \\
\hline 66 & 80 & 66 & 13 \\
\hline 85 & 71 & 67 & 11 \\
\hline 133 & 71 & 68 & 9 \\
\hline 157 & 78 & 70 & 9 \\
\hline 229 & 77 & 71 & 9 \\
\hline 253 & 82 & 72 & 9 \\
\hline 277 & 69 & 72 & 9 \\
\hline 301 & 63 & 71 & 9 \\
\hline 331 & 47 & 69 & 11 \\
\hline 402 & 65 & 68 & 10 \\
\hline 421 & 69 & 68 & 10 \\
\hline 427 & 21 & 65 & 16 \\
\hline 445 & 21 & 62 & 19 \\
\hline 474 & 32 & 60 & 20 \\
\hline 495 & 29 & 58 & 21 \\
\hline 498 & 31 & 57 & 21 \\
\hline 589 & 71 & 58 & 21 \\
\hline 613 & 75 & 58 & 21 \\
\hline 637 & 65 & 59 & 20 \\
\hline 661 & 64 & 59 & 20 \\
\hline 733 & 72 & 60 & 19 \\
\hline 764 & 66 & 60 & 19 \\
\hline 781 & 44 & 59 & 19 \\
\hline 830 & 64 & 59 & 19 \\
\hline 907 & 61 & 59 & 18 \\
\hline 927 & 58 & 59 & 18 \\
\hline 949 & 60 & 59 & 18 \\
\hline 975 & 99 & 61 & 19 \\
\hline 1148 & 112 & 62 & 21 \\
\hline 1167 & 92 & 63 & 21 \\
\hline 1237 & 84 & 64 & 21 \\
\hline 1261 & 83 & 64 & 21 \\
\hline 1285 & 71 & 65 & 21 \\
\hline
\end{tabular}

From a linear fit of the soluble boron data and assuming 4 moles of benzene produced per mole of soluble boron, a benzene generation rate of $1.4 \mathrm{mg} / \mathrm{L}-\mathrm{h}$ is determined (see Table IV). The lower and upper $95 \%$ confidence intervals provided a minimum rate of zero and maximum rate of $6.8 \mathrm{mg} / \mathrm{L}-\mathrm{h}$ (see Table IV). A benzene generation rate of $1.5 \mathrm{mg} / \mathrm{L}-\mathrm{h}$ is obtained using the soluble boron concentration change over the time interval from 590 to 1285 hours. These rate are much greater than the rate determined from periodic sampling of the purge gas (i.e., $0.065 \mathrm{mg} / \mathrm{L}-\mathrm{h}$ ). 


\section{Figure 3. Concentration Changes During Batch 2, 2U and 2A Tests}

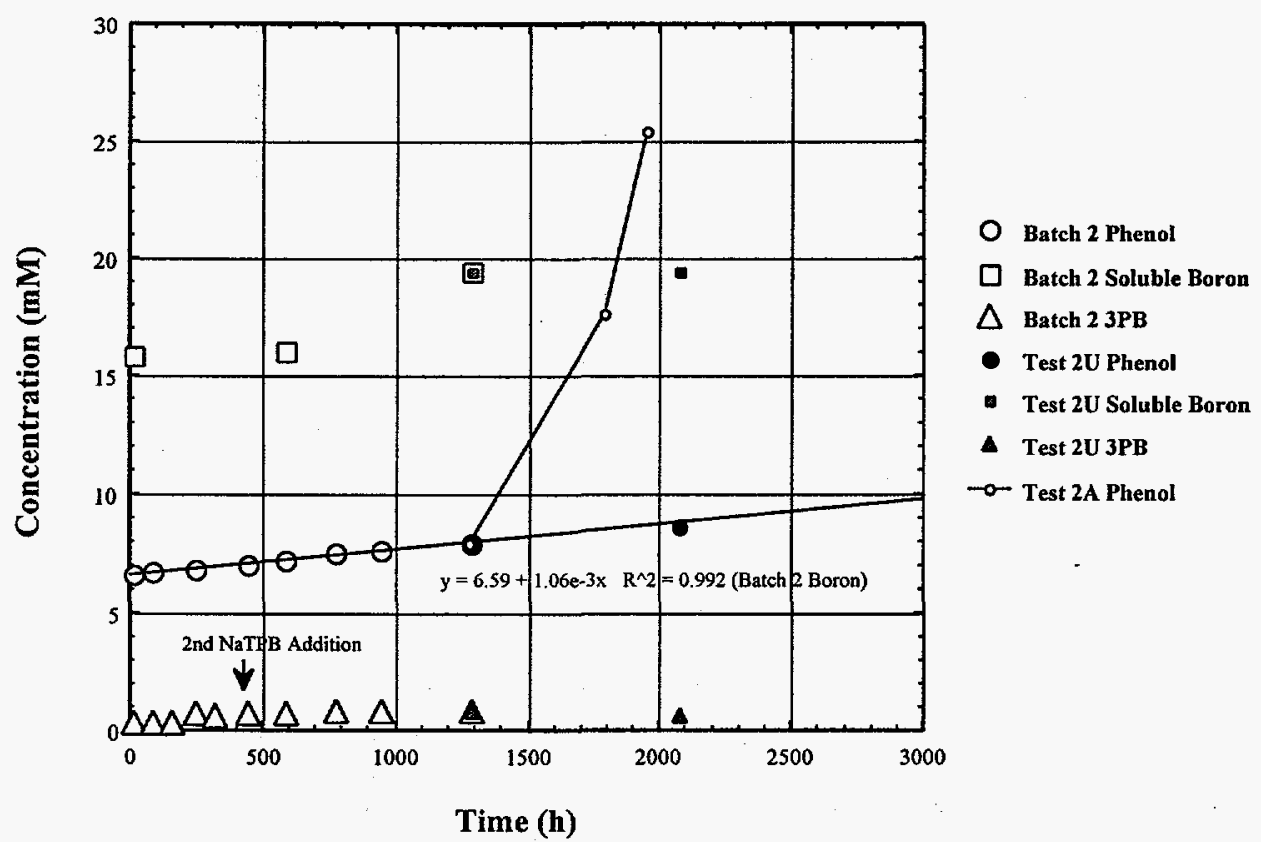

Appreciable leakage or sorption of the benzene is not expected in this reaction system since the purge gas flowrates into the reactor vessel and the flowrates after the sampling port agreed well. Significant sorption of benzene in the stainless steel gas lines after exiting the reactor is also unlikely, although some benzene may sorb into the two O-rings downstream of the glass reactor in the purge gas system..

Accumulation and non-uniform release of the benzene could result in low benzene measurements if all of the sampling periods occurred during accumulation and low release intervals. Higher release rates were observed on two occasions during the batch reactor test when the contents of the reactor were not mixed for a period of time as a result of the magnetic stirrer not operating properly. When stirring resumed, elevated levels of benzene were immediately detected in the gas phase. After several hours, the benzene concentration returned to values comparable to those previously measured. Thus, a non-uniform release of benzene likely did not occur. However, non-uniform release cannot be ruled out conclusively, since the purge gas not sampled continuously.

A rapid NaTPB decomposition reaction may have initiated during Batch 2 sometime between 590 and 1285 hours as evidenced by the apparent jump in soluble boron concentrations in the samples taken at these two times. Also, the concentration of 3PB increased to about 195 $\mathrm{mg} / \mathrm{L}$ between 590 and 783 hours after remaining fairly constant at about $165 \mathrm{mg} / \mathrm{L}$ for the previous 340 hours. Alternatively, the apparent jump in the boron concentration may just reflect data scatter due to sampling and analytical errors with the observed linear increase in soluble boron concentration resulting from background radiolytic/thermal decomposition of 
NaTPB. A benzene generation rate of $1.4 \mathrm{mg} / \mathrm{L}-\mathrm{h}$ determined from the linear fit of the data is not significantly different from that measured $(1.5 \mathrm{mg} / \mathrm{L}-\mathrm{h})$ by from the change in soluble boron concentrations in the interval between 590 and 1285 hours.

The rate of phenol production relative to boron also changed between 590 and 1285 hours as shown in Figure 4. Phenol production requires the presence of an oxygen species. Possible oxygen species include dissolved oxygen, water radiolysis products such as peroxide and hydroxyl radical, or inorganic oxidants such as chromate, nitrate and nitrite. The decrease in the phenol production rate suggests that the reaction slurry became anoxic during this interval.

Figure 4. Plot of Molar Ratio of Phenol to Soluble Boron in Batch 2, Test 2U, Test $2 B$ and Test $2 C$

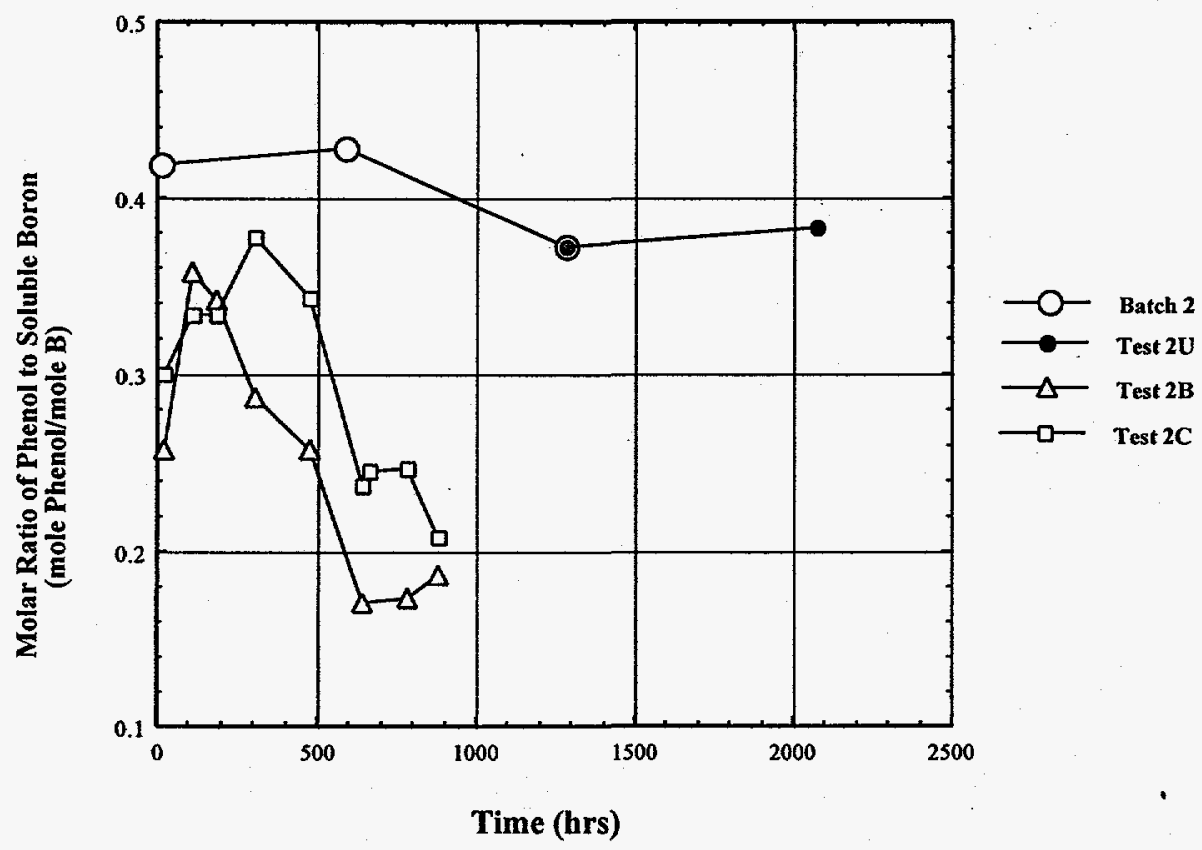

Test 2U

Based on the measurements for soluble boron and phenol concentrations in the unagitated stage, Test $2 \mathrm{U}$, stopping the stirring and nitrogen purge either stopped the rapid reaction, if present, or decreased the rate of the background radiolytic/thermal reactions. This conclusion is based on finding no change in the soluble boron concentration, a decrease in the $3 \mathrm{~PB}$ concentration and no further change or perhaps a small increase in the relative rates of phenol and soluble boron formation after allowing the slurry to stand unagitated

and unpurged for 793 hours ( 2078 hours after initiating the Batch 2 test). If anoxic conditions and a rapid.NaTPB decomposition reaction had initiated during the latter stage of 
the Batch 2 test, the relative rates of phenol and soluble boron formation should continue to decrease provided no other changes in the reactive system occurred. Although the system was closed under nitrogen, sufficient air may have diffused to return the slurry to an oxidizing state, which could terminate rapid NaTPB decomposition.

The quantity of benzene produced during Test $2 \mathrm{U}$ is unknown. Based on the gas phase measurements during the Batch 2 test, the quantity of benzene produced during $2 \mathrm{U}$ is estimated at $30 \mathrm{mg}(50 \mathrm{mg} / \mathrm{L})$. Based on the soluble boron measurements, the quantity of benzene is estimated at $600 \mathrm{mg}(1100 \mathrm{mg} / \mathrm{L})$. The lower concentration is below the solubility limit for benzene in high sodium ion salt solutions and below that in the ECC catalyst testing which demonstrated rapid NaTPB decomposition. The latter value is above the solubility limit and greater than the level $(720 \mathrm{mg} / \mathrm{L})$ demonstrated to be a necessary component for the rapid NaTPB decomposition reaction[16]. As a result of the uncertainty in the true benzene generation rate during Batch 2, one cannot conclude that there was sufficient benzene present to initiate a rapid $\mathrm{NaTPB}$ decomposition reaction.

\section{Test 2A}

Increasing the temperature to $55^{\circ} \mathrm{C}$ (Test $2 \mathrm{~A}$ ) significantly increased the rate of production of phenol (see Figure 2). Cesium-137 decontamination persisted at 504 hours, but was lost between 504 and 668 hours at $55^{\circ} \mathrm{C}$. Thus, the excess NaTPB present after the 1285 hour incubation period for Batch 2 completed reaction between 504 and 668 hours at $55^{\circ} \mathrm{C}$. After correcting for boron leaching from glass (see Appendix 9.13), the data showed a significant change in soluble boron concentration from $0.019 \mathrm{M}$ to $0.079 \mathrm{M}$ after 504 hours and $0.38 \mathrm{M}$ after 668 hours. These values do not agree with the Cs- 137 data and overall boron mass balance.

The maximum possible soluble boron concentration is $0.73 \mathrm{M}$, assuming all of the excess NaTPB and precipitated Cs/KTPB (both freshly precipitated and that present in the Tank $48 \mathrm{H}$ composite material) decomposed. Clearly this decomposition has not occurred since Cs- 137 activities in the two samples, $0.77 \mathrm{nCi} / \mathrm{g}$ and $79 \mathrm{nCi} / \mathrm{g}$ at 504 and 668 hours, respectively, indicated only a small fraction of the Cs/KTPB reacted. Alternatively, the correction factors used to correct boron values due to glass leaching are too low. In either case,the boron results for the Test $2 \mathrm{~A}$ samples are apparently in error and, thus prevent the determination of a reliable estimate of the benzene generation rate from the soluble boron measurements.

However, one may estimate a rate for Test $2 \mathrm{~A}$ based on the time at which the cesium-137 DF was lost. At that time, excess NaTPB cannot exist in the reaction system. As indicated above, the calculated initial excess NaTPB concentration in Batch 2 was $0.013 \mathrm{M}$. A conservative assumption is that none of the excess NaTPB reacted when the portion of Batch 2 slurry was taken to start Test $2 \mathrm{~A}$ (i.e., all of the excess NaTPB was available to react at the start of Test 2A). Based on linearly interpolating the Cs-137 activity data, the Cs-137 activity reached $30 \mathrm{nCi} / \mathrm{g}$ after 566 hours at $55^{\circ} \mathrm{C}$. From the excess NaTPB concentration and the estimated time to reach $30 \mathrm{nCi} / \mathrm{g}$, a maximum benzene generation rate of $7.2 \mathrm{mg} / \mathrm{L}-\mathrm{h}$ is calculated (reported as the maximum value in Table IV). Note that the maximum value is not necessarily conservative since the duration of the 
reaction could have been shorter than the measurement interval resulting in a higher benzene generation rate.

The excess NaTPB concentration at the start of Test 2A can also be estimated from the benzene generation rate determined by gas measurements or soluble boron measurements during Batch 2. From gas measurements, only $2.1 \%$ of the excess NaTPB reacted. From soluble boron measurements, $26 \%$ of the excess NaTPB reacted. Correcting the NaTPB for the gas measurements during Batch 2, the benzene generation rate for Test $2 \mathrm{~A}$ reported above reduced to $7.0 \mathrm{mg} / \mathrm{L}-\mathrm{h}$ (reported as the average value in Table IV). Correcting the excess NaTPB for the soluble boron measurements during Batch 2, the excess NaTPB concentration at the start of Test $2 \mathrm{~A}$ is $0.0096 \mathrm{M}$, resulting in a benzene generation rate of 5.3 $\mathrm{mg} / \mathrm{L}-\mathrm{h}$ (reported as the minimum value in Table IV).

Tests $2 \mathrm{~B}$ and $2 \mathrm{C}$

The highest benzene generation rates occurred in Tests $2 \mathrm{~B}$ and $2 \mathrm{C}$. Figures 5 and 6 plot intermediates and soluble boron concentrations versus time for Test $2 \mathrm{~B}$ and $2 \mathrm{C}$, respectively. Initially, these tests were prepared as duplicates. However, a second addition of NaTPB was made to Test $2 \mathrm{~B}$ after 151 hours while a second addition of NaTPB to Test $2 \mathrm{C}$ occurred after 648 hours.

Increases in intermediates occurred after 186 hours in Test 2B and after 375 hours in Test $2 \mathrm{C}$. For Test $2 \mathrm{~B}$, the rapid reaction occurred after the second NaTPB addition and much sooner than in Test $2 \mathrm{C}$. The rapid reaction clearly began in Test $2 \mathrm{C}$ before the second NaTPB addition. This suggests that the addition of solid NaTPB did not directly initiate the rapid reaction, but may have affected the duration of the induction period. Perhaps the other organic compounds (e.g., 3PB, 2PB, 1PB) in the solid NaTPB scavenged oxygenating species, resulting in Test $2 \mathrm{~B}$ becoming anoxic before Test $2 \mathrm{C}$. The affect does not correlate entirely with the molar excess of NaTPB since a similar behavior occurred in Tests 4A and $4 \mathrm{C}$ (see discussion below) which are comprised of different waste materials and have significantly different levels of excess NaTPB.

Another factor that may have contributed to the development of the rapid NaTPB decomposition in Tests $2 \mathrm{~B}$ and $2 \mathrm{C}$ is the brief period of time (ca. 12 hours) at the start of the tests when the slurries were heated to and maintained at $49 \pm 1{ }^{\circ} \mathrm{C}$. Although a rapid reaction was not immediately observed, catalyst formation reactions may have initiated during this stage as a result of the slightly higher temperature. Prior to the observed rapid reaction in Tank $48 \mathrm{H}$ after completion of Batch 1 , the temperature of the tank contents were reported to have reached $52{ }^{\circ} \mathrm{C}[23]$. The development of the rapid reaction system cannot be attributed to the unidentified components in the solid Aquafine NaTPB since the rapid reaction initiated in Test $2 \mathrm{C}$ prior to the solid NaTPB addition.

The reaction slurry is believed to have become anoxic in Tests $2 \mathrm{~B}$ and $2 \mathrm{C}$, as evidenced by the decreasing molar ratio of phenol to soluble boron (see Figure 4). Initially the ratio increased, but the ratio began falling concurrent with the increase in intermediates. The ratio 
continued to fall for the remainder of Test $2 \mathrm{C}$ and until near the end of Test $2 \mathrm{~B}$. In Test $2 \mathrm{~B}$ the combination of decreasing slurry volume as samples are removed and air in-leakage toward the end of the test may be sufficient to make the system more oxidizing, as evidenced by an increase in the phenol production rate relative to soluble boron (see Figure 4). Oxygen leakage into the carbon steel vessels has been reported by other researchers[10].

Figure 5. Concentration Changes During Test 2B

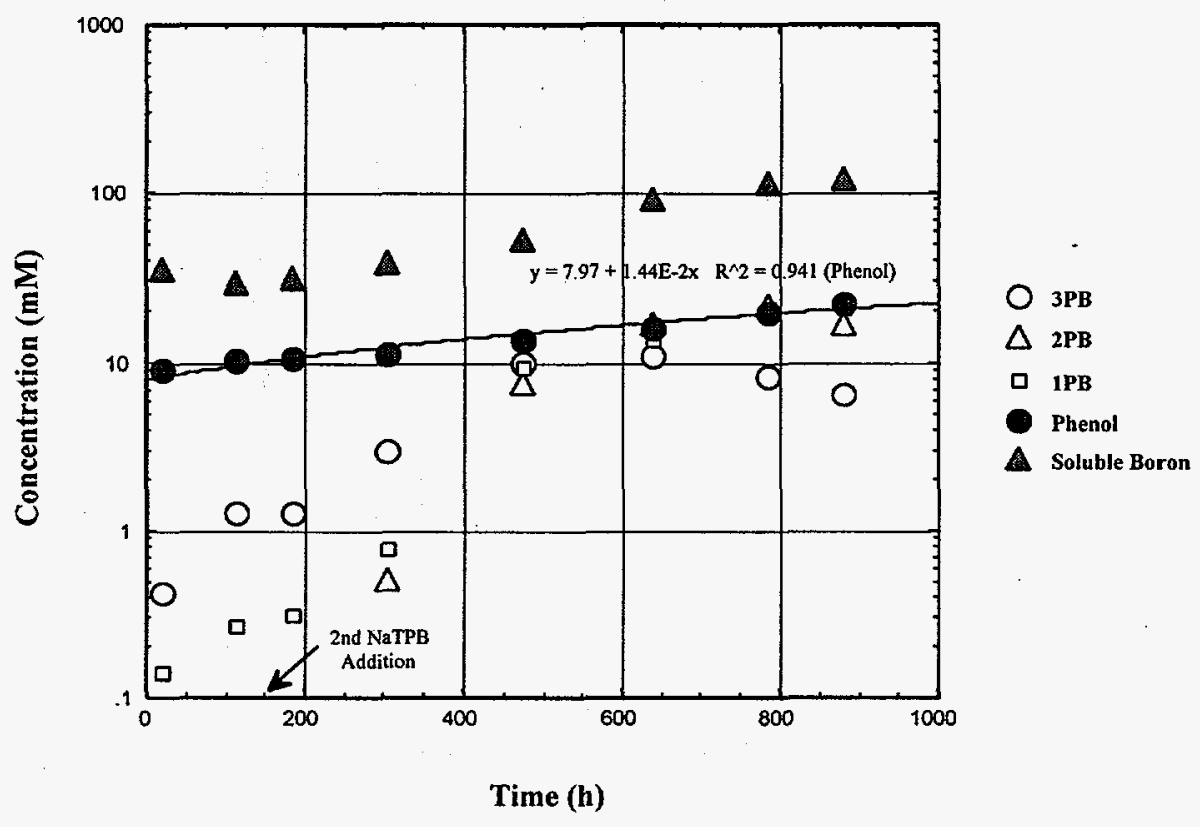


Figure 6. Concentration Changes During Test 2C

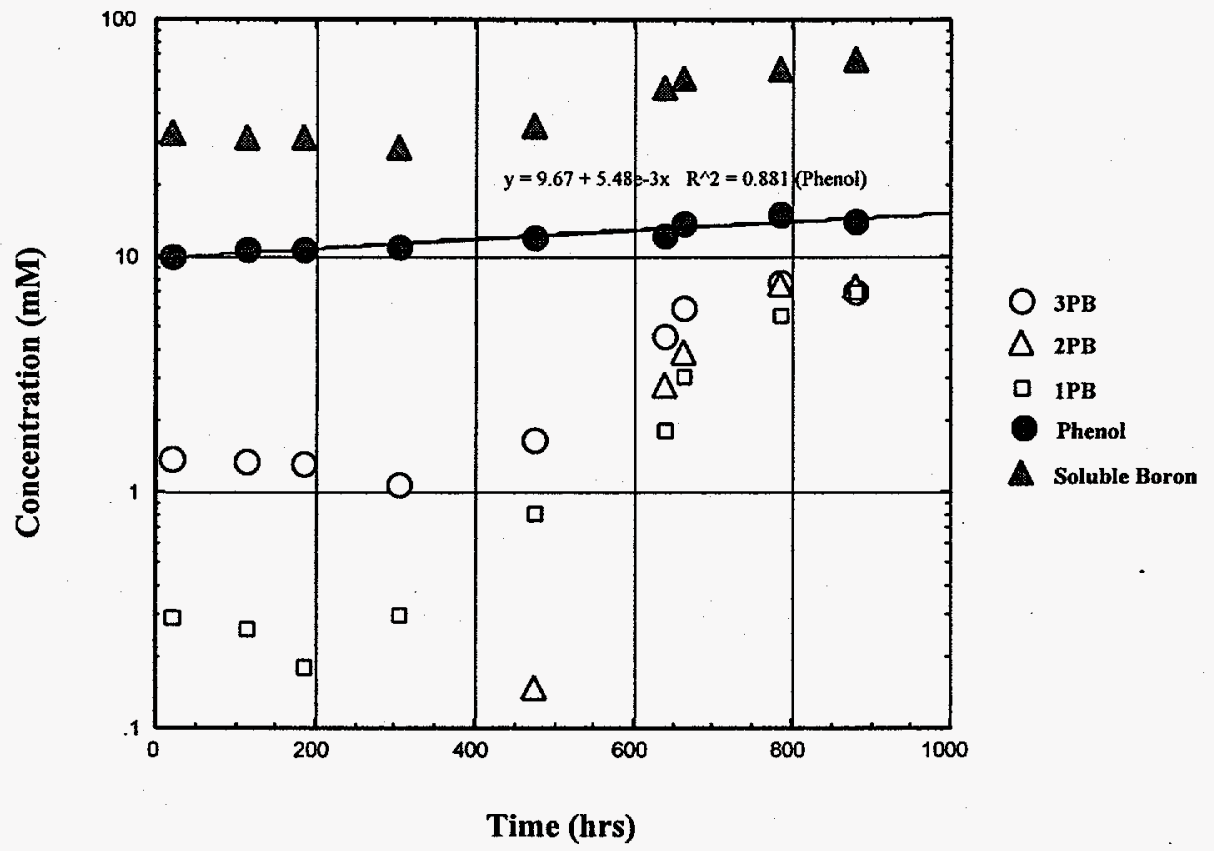

Tests $3 \mathrm{~A}$ and $3 \mathrm{C}$

These set of tests simulated the planned Batch 3 of Cycle 1. Test $3 \mathrm{~A}$ used 'heel' material from Test $2 \mathrm{~B}$, whereas Test $3 \mathrm{C}$ used residual material from the Batch 2 test. Compared to the Batch 2 tests, the Batch 3 tests include four additional waste materials: Tank $32 \mathrm{H}$ supernate, Tank $34 \mathrm{~F}$ supernate, Tank $39 \mathrm{H}$ supernate and Tank $11 \mathrm{H}$ sludge.

The first addition of NaTPB made to each test slurry was based on a calculated potassium concentration. 'TPB Demand' measurements indicated the calculated potassium concentration was low for Test $3 \mathrm{~A}$ and, therefore, insufficient NaTPB was added in this test to complete cesium and potassium precipitation. This was confirmed when a second NaTPB addition made to Test $3 \mathrm{~A}$ based on 'TPB Demand' concentration successfully achieved Cs137 decontamination.

For Test 3C, the TPB demand result, $0.089 \mathrm{M}$ (see Table II) is believed to be in error since the makeup of this test should have a similar 'TPB Demand' value to $3 \mathrm{~A}$. The high 'TPB Demand' value is believed to result from the precipitate solids not being completely dry before weighing. In fact, $\mathrm{Cs}-137 \mathrm{DF}$ was briefly achieved in Test $3 \mathrm{C}$ indicating that there was a slight excess of NaTPB at the start of the test. The additional NaTPB was provided by the Batch 2 slurry added in the makeup of this test. The exact mole ratio of NaTPB to 'TPB demand' in these tests is uncertain because the amount of excess NaTPB solids carried over from the Test $2 \mathrm{~B}$ and Batch 2 slurries is unknown. However, since 
Cs-137 DF was obtained initially in Test 3C, the actual 'TPB Demand' value for Test 3C must be closer to the calculated potassium concentration of $0.015 \mathrm{M}$ than $0.089 \mathrm{M}$.

Plots of intermediates, phenol and soluble boron data versus time for Tests $3 \mathrm{~A}$ and $3 \mathrm{C}$, are provided in Figures 7 and 8, respectively. A benzene generation rate for the decomposition of NaTPB could not be determined because of the lack of data when excess NaTPB present (i.e., Cs-137<30 nCi/g - see Figure 9). An excess of NaTPB was present for a short period of time as evidenced by achievement of Cs DF at 618 hours, 90 hours after the second NaTPB addition. After another 72. hours, the Cs DF had been lost indicating decomposition of all excess NaTPB. Assuming the excess NaTPB $(0.00224 \mathrm{M})$ had reacted completely immediately after sampling at 618 hours, the benzene generation rate for Tests $3 \mathrm{~A}$ and $3 \mathrm{C}$ is calculated to be $7.8 \mathrm{mg} / \mathrm{L}-\mathrm{hr}$.

The cesium-137 DF was lost during Tests $3 \mathrm{~A}$ and $3 \mathrm{C}$, indicating that all excess NaTPB reacted. After loss of cesium-137 DF, any increase in soluble boron concentration must be due to the decomposition of solid cesium and potassium tetraphenylborate (Cs/KTPB). Benzene generation rates for solid $\mathrm{Cs} / \mathrm{KTPB}$ were determined from the slope of a linear fit of the Cs-137 activity data plotted versus time (see Figure 9) and assuming a ratio of Cs-137 to potassium entering the liquid phase of $60 \mathrm{nCi} \mathrm{Cs}-137 / \mathrm{g} \mathrm{K}$ (see Appendix 9.17 for details). The slopes of the linear fit are reported as the average value in Table $\mathrm{V}$. The lower and upper $95 \%$ confidence limits about the linear fit were used to determine the minimum and maximum generation rates.

Figure 7. Concentration Changes During Test 3A

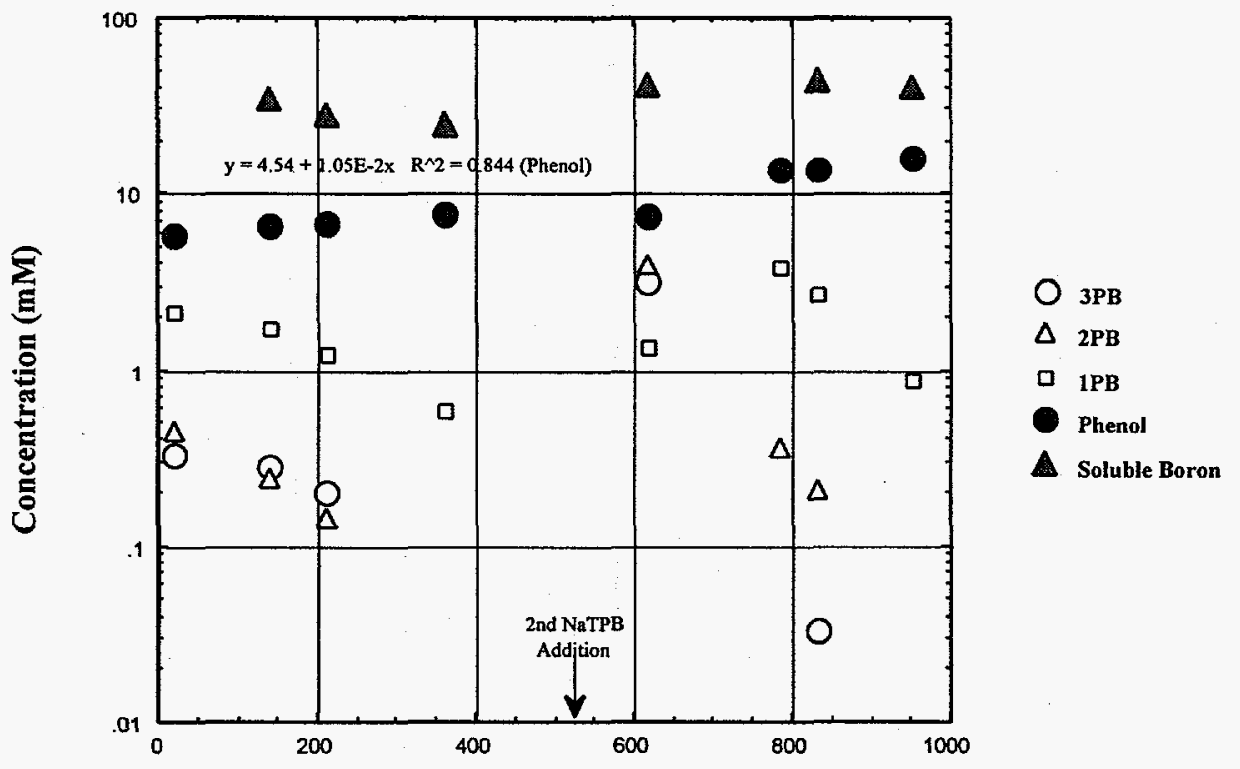

Time (h) 
Figure 8. Concentration Changes During Test 3C

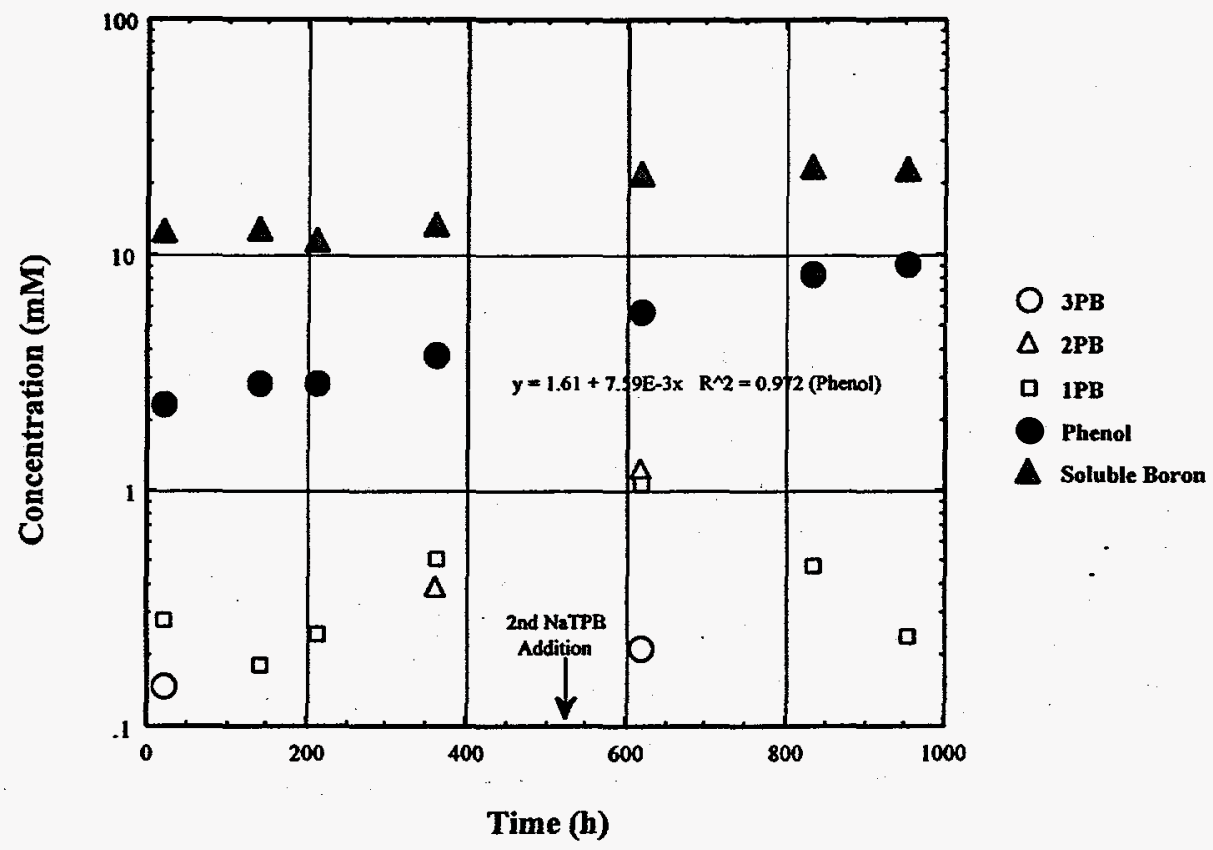

Figure 9. Cs-137 Activity Changes with Time in Tests $3 \mathrm{~A}$ and $3 \mathrm{C}$

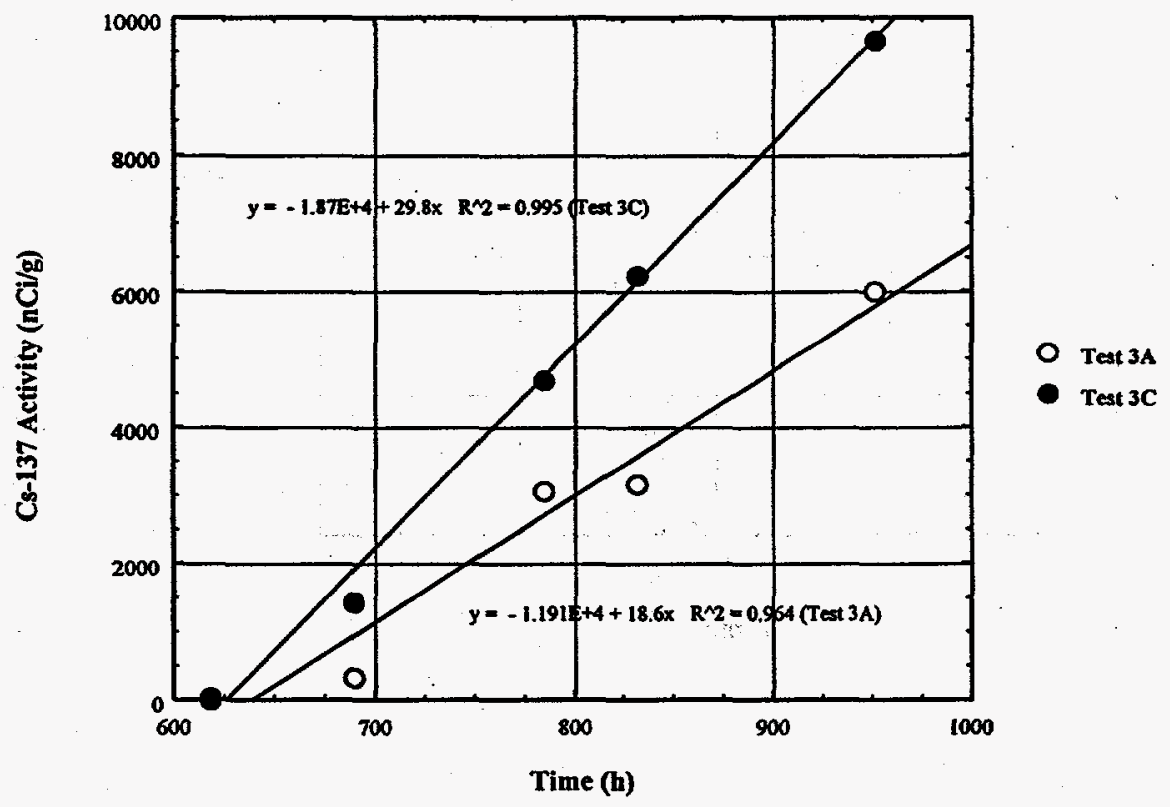


Plots of the molar ratios of phenol to soluble boron for Tests $3 \mathrm{~A}$ and $3 \mathrm{C}$ are provided in Figure 10. Initially, the ratio increased, with Test $3 \mathrm{~A}$ showing a greater increase than Test 3C. This suggests that less oxidizing conditions existed in Test $3 \mathrm{C}$, which is also consistent with Test $3 \mathrm{C}$ having more NaTPB than Test $3 \mathrm{~A}$ initially. After the second addition of NaTPB, the ratio decreased, indicating the possibility of the reaction system becoming anoxic. Perhaps organic compounds in the NaTPB solution react with oxygen and oxygenating species to make the system more reducing. However, after depletion of the excess NaTPB, the ratio began increasing suggesting the system returned to a more oxidizing condition.

Observed induction times, benzene generation rates from $\mathrm{NaTPB}$ decomposition and benzene generation rates from Cs/KTPB decomposition for Cs/KTPB decomposition in Tests $3 \mathrm{~A}$ and $3 \mathrm{C}$ were not significantly different. These results suggest that subjecting Batch 2 material to an additional incubation period at high NaTPB excess did not significantly affect either the initiation or the rate of the Batch 3 TPB decomposition. Comparing the NaTPB decomposition rates for Batch $3(7.8 \mathrm{mg} / \mathrm{L}-\mathrm{h})$ to Batch $2(1.5 \mathrm{mg} / \mathrm{L}-\mathrm{h})$, suggests that the introduction of the four new waste materials increased the rate of NaTPB decomposition at $45^{\circ} \mathrm{C}$ and low molar NaTPB excess. The greater reactivity may possibly be due to changes in metal concentrations between the two batches.

Figure 10. Molar Ratio of Phenol to Soluble Boron in Tests 3A and 3C

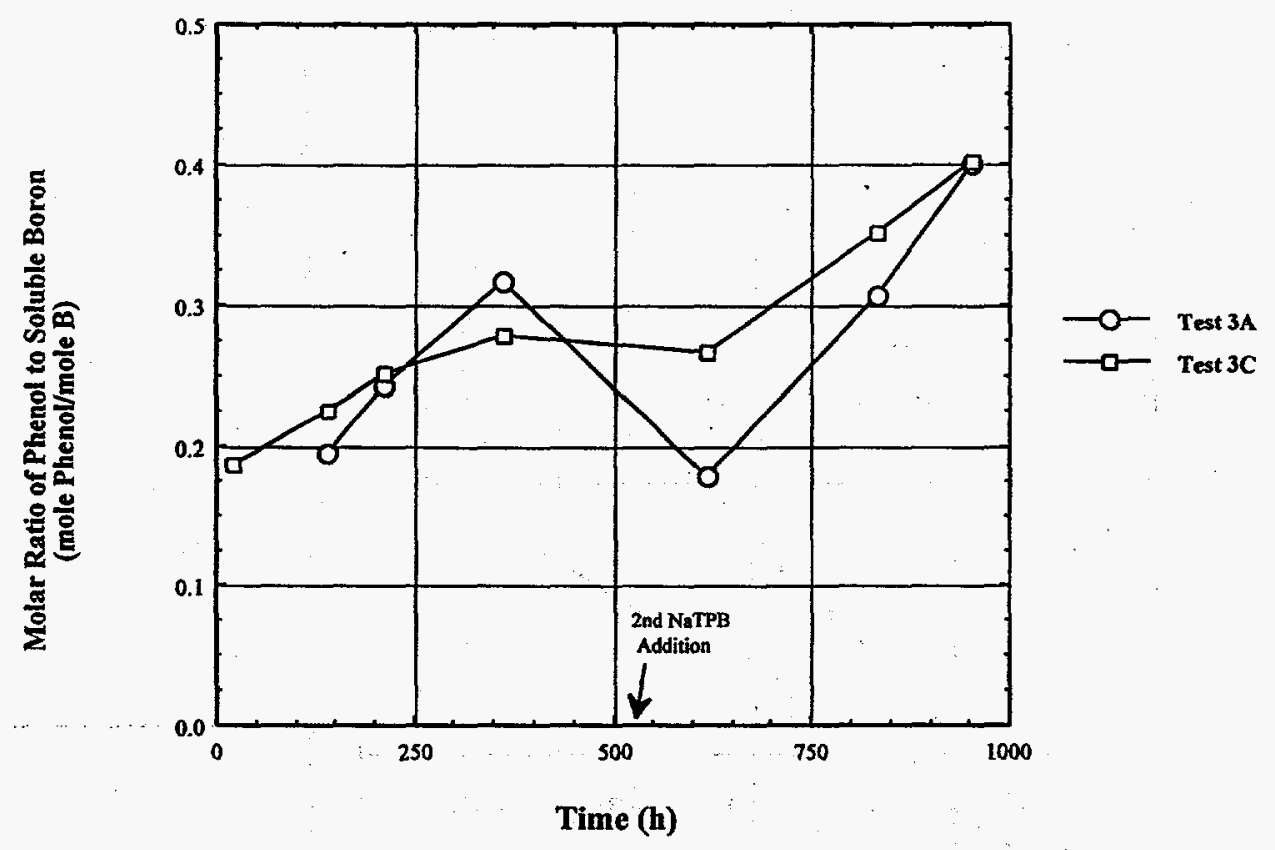


Tests 3B, 3D, 4A and 4C

Tests 3B, 3D, 4A and 4C simulated the planned Batch 4 of Cycle 1. Tests $4 \mathrm{~A}$ and $4 \mathrm{C}$ are the sequential batch tests following Batch 3 tests, $3 \mathrm{~A}$ and $3 \mathrm{C}$, respectively. Tests $3 \mathrm{~B}$ and $3 \mathrm{D}$ used 'heel' material from Test $2 \mathrm{C}$ and Batch 2 , respectively, scaled appropriately to provide the relative volumes for Batch 4. Tests 3B and 3D tests are not sequential tests and, therefore, did not receive a second precipitation and incubation period as in the case of Tests $4 \mathrm{~A}$ and $4 \mathrm{C}$.

Plots of the concentration changes with time for Tests 3B, 3D, 4A and $4 \mathrm{C}$ are provided in Figures 11-14. As discussed earlier for Test 3A, Tests 3B and 3D did not have an excess of NaTPB until the second addition at 528 hours into the tests. A rapid NaTPB reaction may have initiated in these tests between the time of the second NaTPB addition and the time at which the next sample was taken (618 hours), as evidenced by increases in the 3PB and 2B concentrations in Test 3B and 3PB concentration in Test 3D. The next sample taken in Test 2B analyzed for organics and soluble boron at 832 hours ( 290 hours after NaTPB addition) clearly showed evidence of a rapid NaTPB reaction occurring. Concentrations of intermediates in Test 3D remained low throughout the test. A large increase in the soluble boron concentration occurred between 951 and 1504 hours into the test suggesting a rapid NaTPB decomposition reaction is occurring at this time. Because of the long sampling interval, intermediates produced from the decomposition of the NaTPB had reacted.

The target NaTPB excess was $0.00224 \mathrm{M}$ in Tests $3 \mathrm{~B}$ and $3 \mathrm{D}$ and $0.01 \mathrm{M}$ in $4 \mathrm{~A}$ and $4 \mathrm{C}$. The first two samples from Test $4 \mathrm{C}$ exhibited a high Cs-137 activity which was interpreted to indicate that NaTPB was either not added or did not sufficiently mix to achieve cesium precipitation. Therefore, more NaTPB solution was added after 236 hours. Assuming that the first addition was made, the mole ratio of NaTPB to 'TPB Demand' after the second addition was 2.65. This value is very similar to those after the first addition of NaTPB in Tests 2B (2.61) and 2C (2.61).

The final sample taken from $4 \mathrm{C}$ confirmed that the first addition of NaTPB had been made. The soluble boron concentration corresponded to a value that exceeded the theoretical amount from the excess NaTPB in a single addition (i.e., observed $0.016 \mathrm{M}$ increase in soluble boron concentration versus a theoretical maximum concentration of 0.010 with the Cs-137 activity remaining low $(12.9 \mathrm{nCi} / \mathrm{g})$. Some precipitate solids apparently passed through the filter in the first two samples resulting in a high Cs-137 activity in the filtrate.

Acceptable cesium decontamination was achieved in both tests. However, the cesium concentration exceeded $30 \mathrm{nCi} / \mathrm{g}$ in Test $4 \mathrm{~A}$ between 185 and 308 hours after starting the test. Cesium DF was held throughout Test $4 \mathrm{C}$ due to the large excess of NaTPB. Tests $2 B$, $2 \mathrm{C}$ and Test $4 \mathrm{C}$ have the highest mole excess of NaTPB. The average benzene generation rate of Test $4 \mathrm{C}$ is a factor of 5 lower than Test $2 \mathrm{~B}$ and a factor of 2 lower than $2 \mathrm{C}$. Thus, a large benzene generation rate cannot be attributed entirely to the presence of a large excess of NaTPB. 
The rapid decomposition of excess NaTPB occurred between 18 and 185 hours in Test 4A, as evidenced by increases in 3PB and 1PB (see Figure 13). Increased 2PB was not observed until 308 hours in Test 4A. In Test 4C, increases in the concentrations of $2 \mathrm{~PB}$ and $1 \mathrm{~PB}$ occurred between 472 and 666 hours (see Figure 14). An increase in the 3PB concentration occurred between 666 and 811 hours into Test $4 \mathrm{C}$.

Test $4 \mathrm{C}$ was the only test that clearly showed a non-linear increase in phenol concentration with time. The non-linear behavior may be an artifact of the test. Test $4 \mathrm{C}$ initiated with only $74 \mathrm{~mL}$ of material. After taking nine samples from the vessel, the test had to be terminated because no further liquid could be drawn into the syringe. Thus, the homogeneity of the latter samples taken from the vessel with low slurry volume is questionable. The scatter in the soluble boron data also supports this explanation.

Figure 11. Concentration Changes During Test 3B

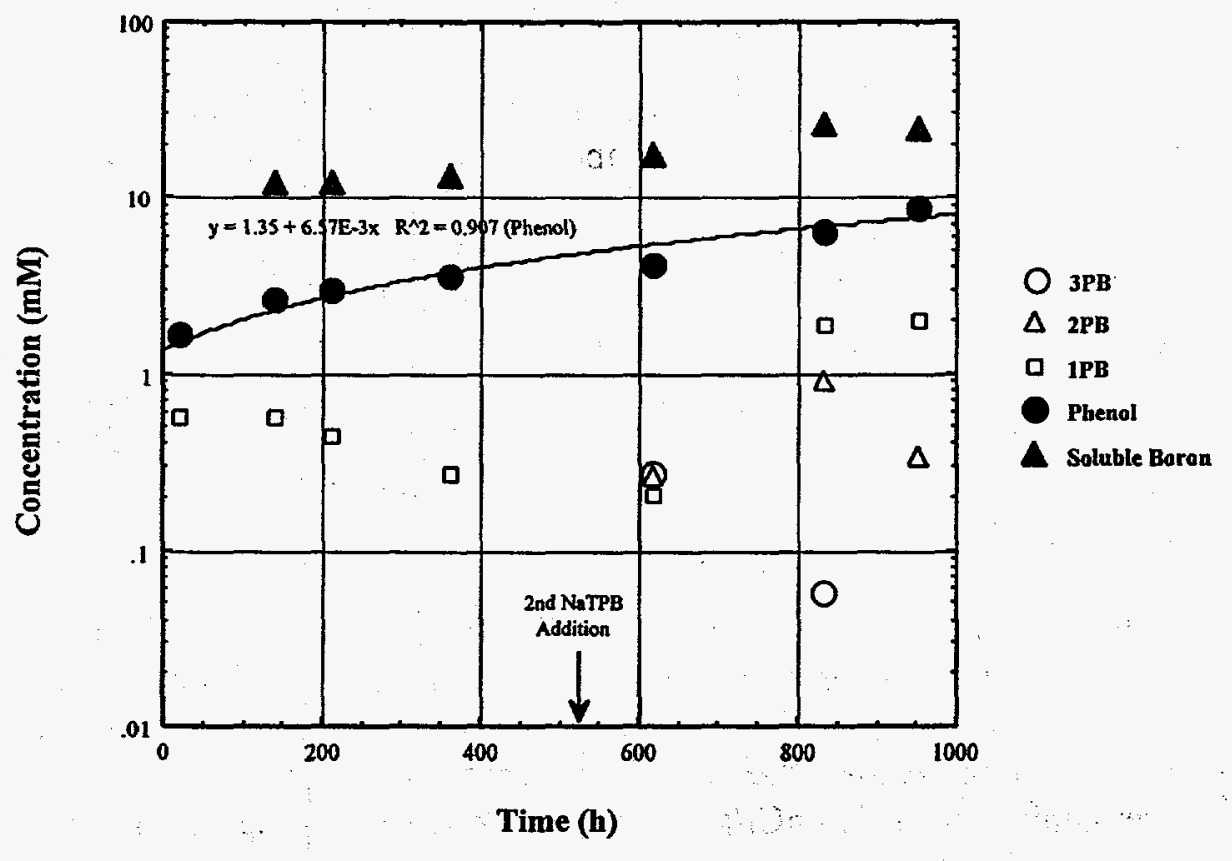


Figure 12. Concentration Changes During Test 3D

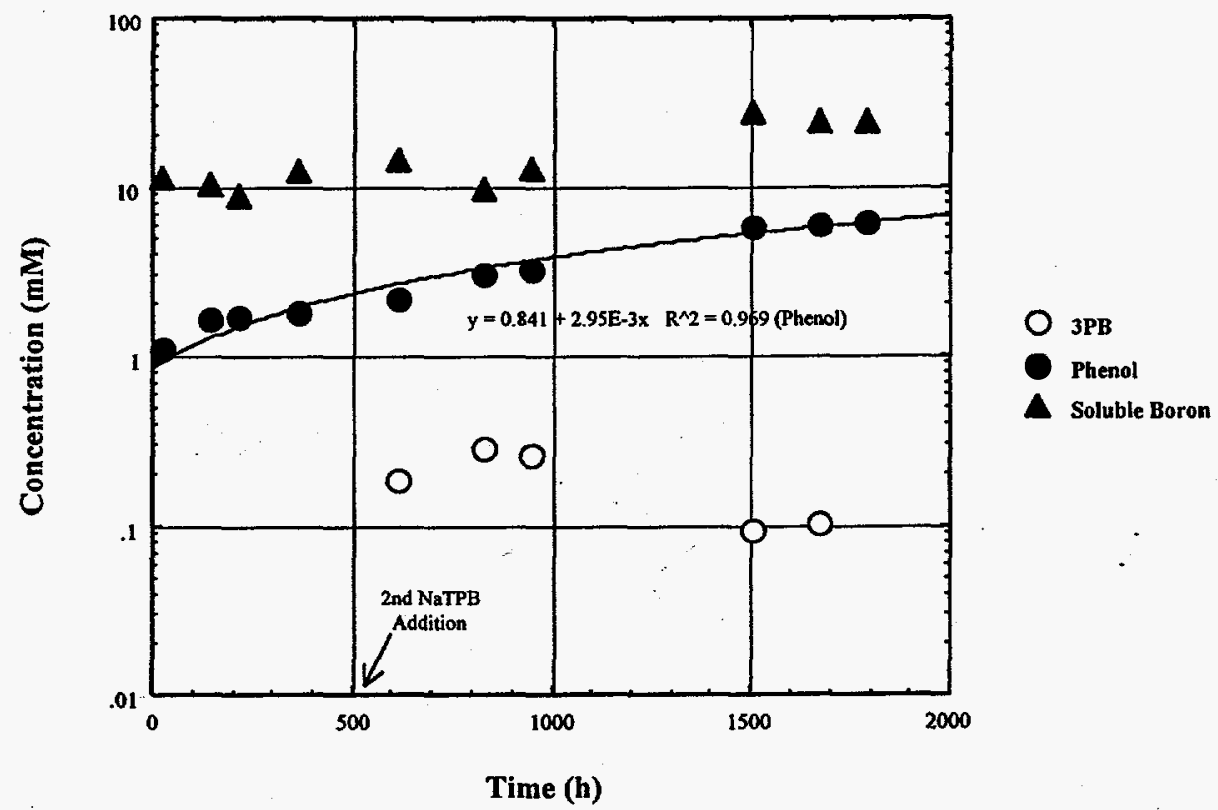

Figure 13. Concentration Changes During Test 4A

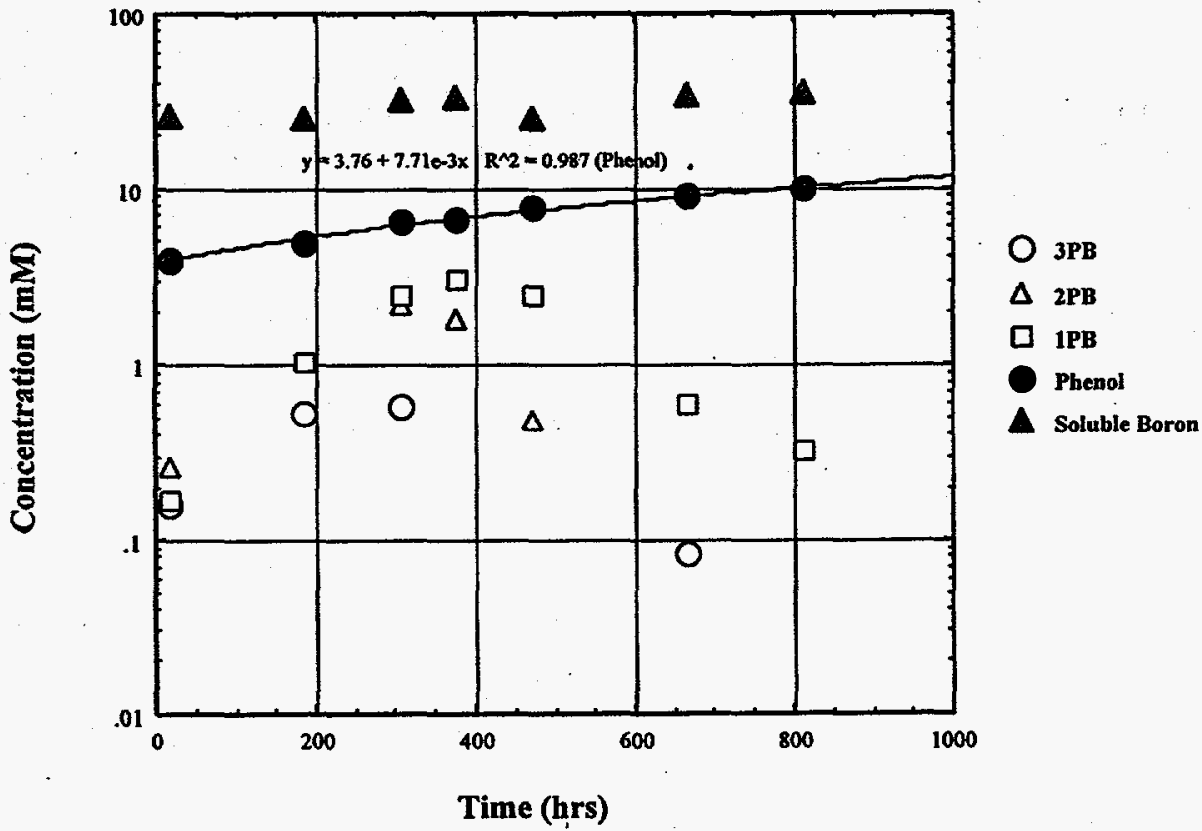


Figure 14. Concentration Changes During Test 4C

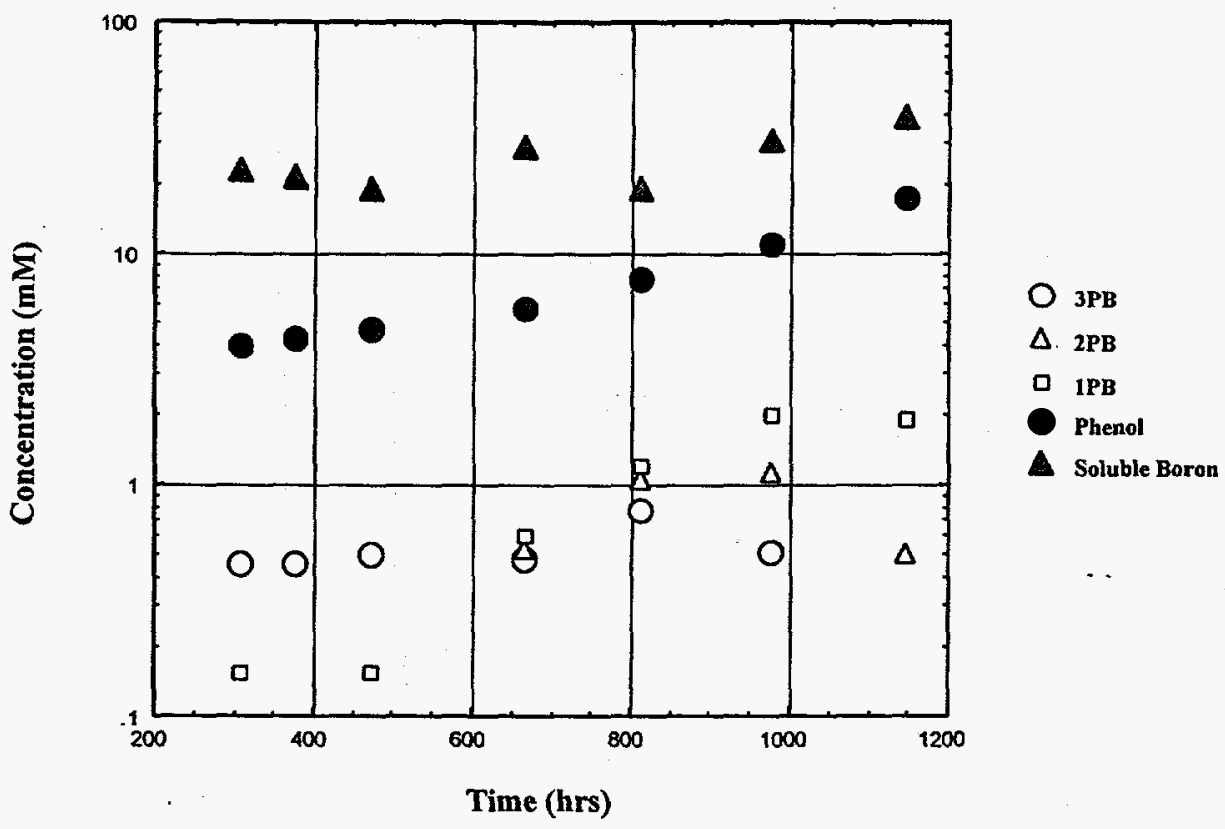

Figure 15 provides a plot of the molar ratio of phenol to soluble boron in Tests $3 \mathrm{~B}, 3 \mathrm{D}, 4 \mathrm{~A}$ and $4 \mathrm{C}$. A sharp decrease in the ratio was observed for Tests 3B, 3D and $4 \mathrm{C}$ immediately following a second addition of NaTPB. Interestingly, Test 4A exhibited the same general trend even though a second NaTPB addition was never made during these tests. This suggests that the observed behavior may be primarily due to the reaction chemistry and not the NaTPB addition. Toward the end of the tests, the molar ratio appeared to increase again. This behavior may be due to sample inhomogeneity masking the ability to detect anoxic conditions by this ratio. 
Figure 15. Molar Ratio of Phenol to Soluble Boron in Tests 3B, 3D, 4A and 4C

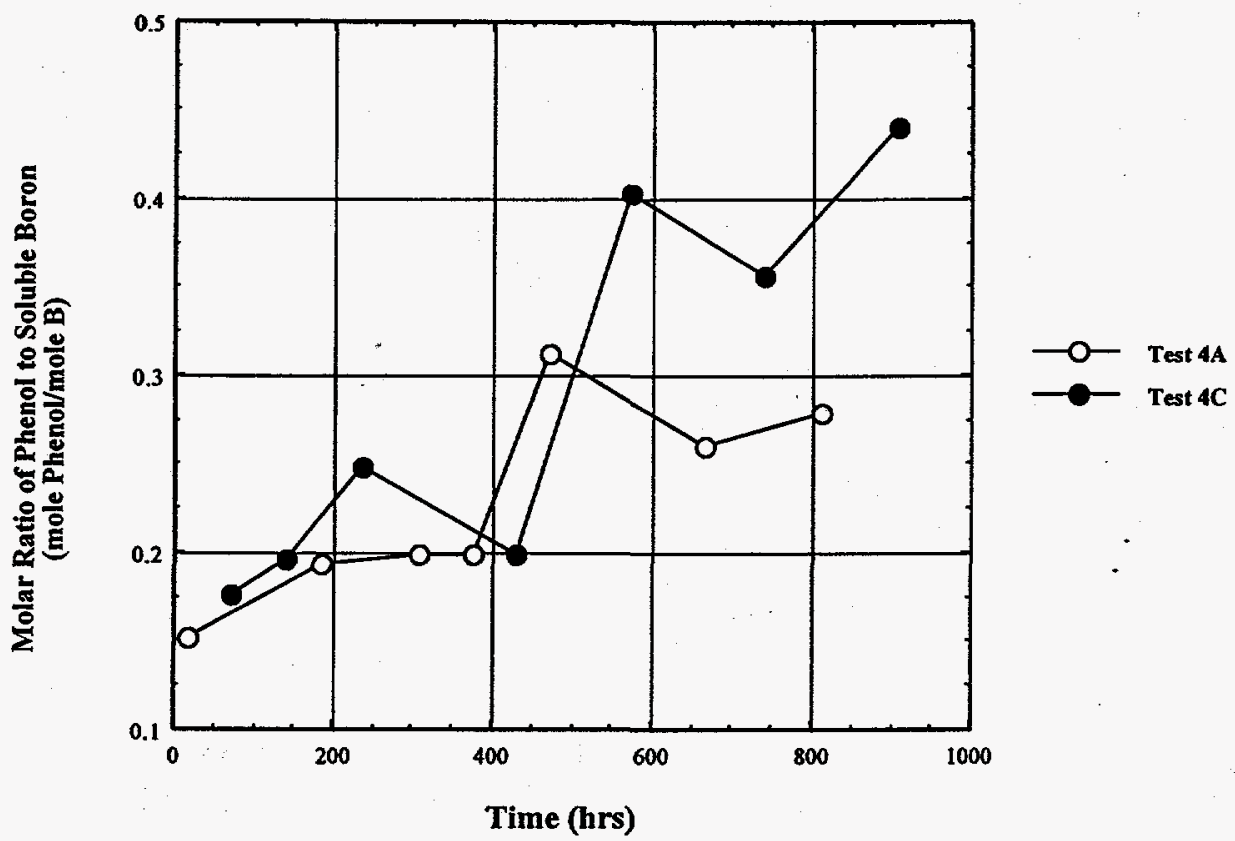

Comparing the results for Tests $4 \mathrm{~A}$ and $4 \mathrm{C}$ with Tests $3 \mathrm{~A}$ and $3 \mathrm{C}$ suggests comparable $\mathrm{NaTPB}$ and $\mathrm{Cs} / \mathrm{KTPB}$ decomposition rates for Batch 3 and Batch 4 compositions. The calculated $\mathrm{Pd}$ concentrations in Tests $4 \mathrm{~A}$ and $4 \mathrm{C}$ are lower than $3 \mathrm{~A}$ and $3 \mathrm{C}$ suggesting that the decomposition rates are not dependent on total $\mathrm{Pd}$ concentration. However, $\mathrm{Cr}, \mathrm{Cu}, \mathrm{Ru}$, $\mathrm{Rh}, \mathrm{Ce}$ and $\mathrm{Hg}$ were present in appreciably higher concentrations in the Batch 3 and Batch 4 tests compared to the Batch 2 tests suggesting one or more of these metals may be involved in the catalytic decompositon of NaTPB. Furthermore, traces amounts of $\mathrm{Re}, \mathrm{Os}, \mathrm{Ir}, \mathrm{Pt}$ and $\mathrm{Au}$ were detected in the some of the waste materials used in Batches 3 and 4 testing, but these metals were not detected in the Batch 2 Feed Slurry.

Comparing the results for Tests $3 B, 3 D$ with Tests $4 A$ and $4 C$ suggests the sequential Batch 4 tests (4A and $4 \mathrm{C}$ ) are more reactive than the non-sequential Batch 4 tests (3B and 3D). Test $4 \mathrm{~A}$ reacted all of the excess $\mathrm{NaTPB}$ and lost Cs-137 DF quickly. Tests $4 \mathrm{C}$ possibly would have reacted all of the excess NaTPB had the second addition not been made. All of the excess NaTPB did not decompose in Tests 3B and 3D even though there was a lower molar excess of NaTPB in these tests compared to Tests $4 \mathrm{~A}$ and $4 \mathrm{C}$.

Comparing the results for the Batch 3 (Tests 3A and 3C) and Batch 4 (Tests 3B, 3D, 4A and 4C) compositions with Batch 2 suggests that the former are more reactive for the decomposition of NaTPB at similar conditions (see Table IV). The greater reactivity is not attributed to the sludge concentration on TPB solids basis since the ratio of sludge solids to (K/Cs)TPB solids is fairly similar for all tests (see Table VIII). There are 
significant changes in major salt component levels and metals concentrations between Batches 2 and Batches 3 and 4. Batches 3 and 4 have lower hydroxide and higher nitrate and nitrite concentrations than in Batch 2. A number of metals including $\mathrm{Ce}, \mathrm{Cu}, \mathrm{Mo}, \mathrm{Hg}, \mathrm{Mn}$, $\mathrm{Ni}$ and $\mathrm{Zn}$ were higher in the Batches 3 and 4 tests compared to Batch 2. These differences in the chemical composition may be responsible for the different NaTPB decomposition rates between Batch 2 and Batches 3 and 4.

Table VIII. Ratio of Sludge Solids to (K/Cs)TPB in Radioactive Tests

$\begin{array}{cc}\frac{\text { Test ID }}{\text { Batch } 2} & \text { Sludge/(K/Cs)TPB }(\mathrm{mg} / \mathrm{mmole}) \text { ' } \\ \text { 3A } & 43 \\ \text { 3B } & 41 \\ \text { 3C } & 44 \\ \text { 3D } & 43 \\ \text { 4A } & 45 \\ \text { 4C } & 39 \\ \text { ' Ratio of sludge concentration in slurry (Table III) to the 'TPB Demand' Value (Table II). }\end{array}$

Test 2.7

Test 2.7 was conducted to determine the effect of lower ionic strength on the decomposition rate. This test also allows a better comparison with simulant tests conducted at a lower sodium ion concentration $(2.7 \mathrm{M})$. The concentrations of NaTPB, intermediates (3PB, 2PB and 1PB), phenol and soluble boron versus time for Test 2.7 are plotted in Figure 16.

In contrast to the other radioactive tests, the initial sample taken after 21.8 hours has an appreciable quantity of NaTPB $(452 \mathrm{mg} / \mathrm{L})$. The higher NaTPB concentration is due to the lower sodium ion concentration. The NaTPB concentration is well below the solubility limit of $5300 \mathrm{mg} / \mathrm{L}[18]$ due to the limited quantity of NaTPB in the test. At 141 hours, the concentration of NaTPB decreased and the intermediates increased, indicating decomposition was in progress. Thereafter, the concentrations of intermediates decreased. Based on these results, the induction time for Test 2.7 was less than 141 hours. The soluble boron concentration increased linearly with time. Based on the soluble boron data, an average benzene generation rate (corrected for losses in NaTPB and intermediates concentrations) was determined to be $20 \mathrm{mg} / \mathrm{L}-\mathrm{h}$. 
Figure 16. Concentration Changes During Test 2.7

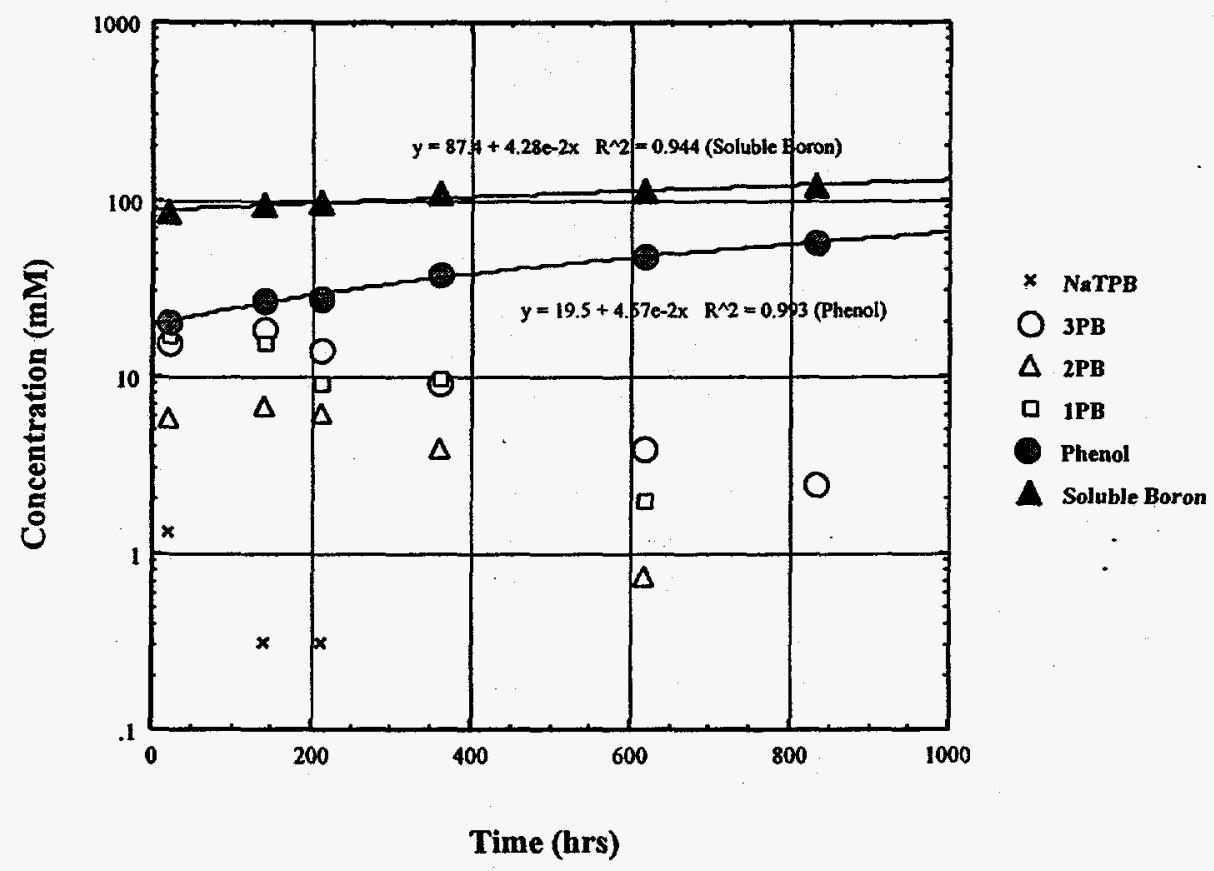

Figure 17 plots the molar ratio of phenol to soluble boron against time in Test 2.7. The molar ratio increases linearly with time, indicating that the reaction slurry remains oxidizing during the entire test. The makeup of this test included material from Tests $2 \mathrm{~B}$ and $2 \mathrm{C}$ which exhibited a rapid NaTPB decomposition. Thus, continuation of the rapid reaction is not necessarily unexpected. Since rapid decomposition appeared to begin early in this test, anoxic conditions are not required to sustain the decomposition of NaTPB. 
Figure 17. Molar Ratios of Phenol to Soluble Boron in Test 2.7.

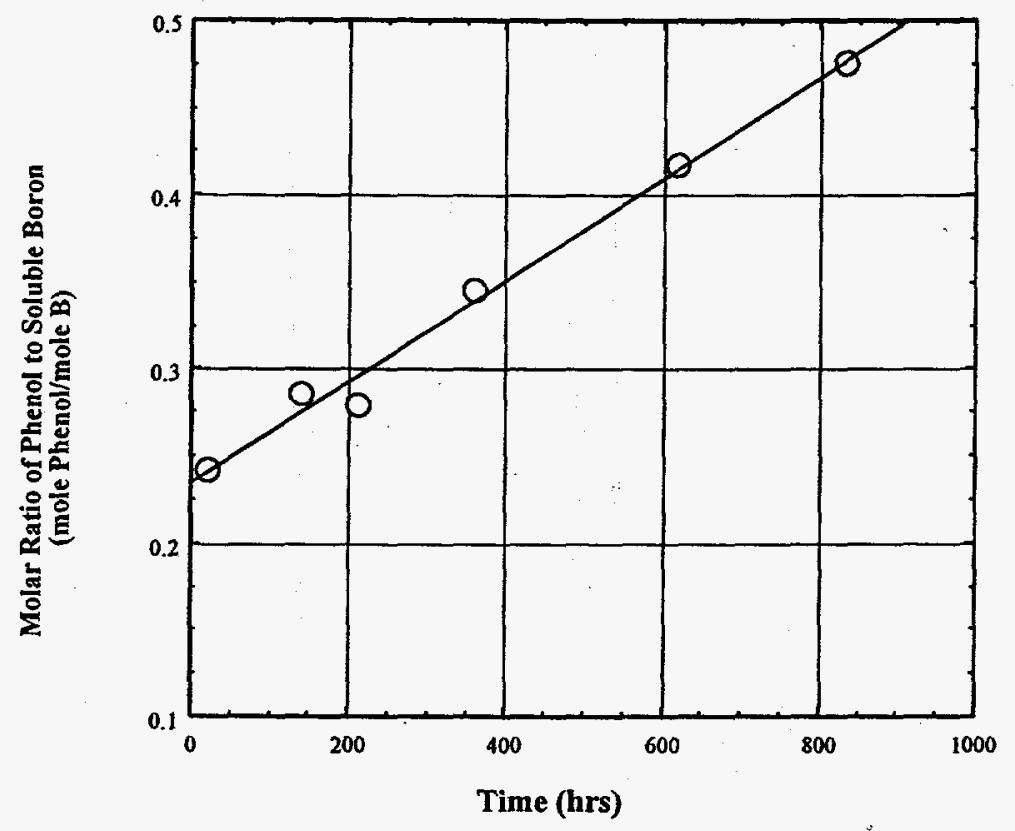

\subsection{Conclusions and Recommendations}

A series of twelve tests examined benzene generation rates with radioactive materials simulating the planned Batches 2 through 4 that complete Cycle 1 for the In-Tank Precipitation (ITP) facility. The following observations come from these tests.

- At bounding facility temperatures and high sludge solids content (i.e., $45^{\circ} \mathrm{C}$ and $>$ $780 \mathrm{mg} / \mathrm{L}$ sludge), seven of the 12 tests exhibited calculated benzene formation rates in excess of $7 \mathrm{mg} / \mathrm{L}-\mathrm{h}$ from decomposition of excess NaTPB based on soluble boron measurements. These results imply the need for changes in current process configuration before resumption of operations.

- Removal efficiency for cesium meets Saltstone criteria at molar NaTPB excesses as low as $8 \%$ of the theoretical equivalent.

- When rapid decomposition (i.e., $>7 \mathrm{mg} / \mathrm{L}-\mathrm{h}$ calculated benzene formation) of excess sodium tetraphenylborate (NaTPB) occurred, the soluble cesium-137 concentration rose above the Saltstone criteria (i.e., $30 \mathrm{nCi} / \mathrm{g}$ ) in a relatively short period of 14 days.

- Direct benzene generation measurements did not agree well with those determined from soluble boron concentrations in the Batch 2 test.

- Batch 3 and Batch 4 compositions appeared more reactive than Batch 2 when compared at the same low molar excess NaTPB conditions. The greater reactivity is attributed to differences in the chemical compositions, specifically higher concentrations of several metals (i.e., $\mathrm{Cu}, \mathrm{Hg}, \mathrm{Ce}, \mathrm{Mo}, \mathrm{Mn}, \mathrm{Ni}$, and $\mathrm{Zn}$ ) and major salt components (i.e., hydroxide, nitrate, nitrite). 
- Three tests provided measurements of decomposition rate for the potassium and cesium tetraphenylborate ((K/CS)TPB) in absence of excess NaTPB. At bounding facility temperatures and high sludge solids content (i.e., $45^{\circ} \mathrm{C}$ and $>780 \mathrm{mg} / \mathrm{L}$ sludge), the (K/Cs)TPB precipitate decomposed at a rate slower than $4.5 \mathrm{mg} / \mathrm{L}-\mathrm{h}$ benzene equivalent.

- The measured reactions followed an induction period of between 0 and 1285 hours. This induction behavior did not correlate well with any measured system parameter or concentration of any identified component. Examination of phenol yield data indirectly suggests a possible role of oxygen or redox state with the induction period.

- Addition of monosodium titanate is not required in Batch 2, but is required in Batches 3 and 4 to meet Saltstone criteria for Sr-90 and total alpha activity.

Comparison of these radioactive tests with simulant experiments provided the following observations.

- The radioactive system contained far less palladium than the concentration typically used in the non-radioactive testing with ECC sludge (i.e., $0.092-0.26 \mathrm{mg} / \mathrm{L}$ in the radioactive tests compared to $2.60 \mathrm{mg} / \mathrm{L}$ in simulant tests).

- The radioactive system contained higher concentrations (i.e., 2 to $160 \mathrm{X}$ ), relative to ECC concentrations of selected metals (i.e., $\mathrm{As}, \mathrm{Ca}, \mathrm{Cd}, \mathrm{Ce}, \mathrm{Co}, \mathrm{Cu}, \mathrm{La}, \mathrm{Mo}, \mathrm{Se}$, and Sr) than previous simulant tests.

- The radioactive system contained lower concentrations (i.e., 2 to $250 \mathrm{X}$ ), relative to $\mathrm{ECC}$ concentrations of selected metals (i.e., $\mathrm{Ag}, \mathrm{Fe}, \mathrm{Hg}, \mathrm{Mn}, \mathrm{Ni}, \mathrm{Pd}$, $\mathrm{Ti}$ and $\mathrm{Zr}$ ) than previous simulant tests.

- The radioactive system contained eight metals (i.e.W, V, Tc, W, Re, Os, Ir , Pt and $\mathrm{Au})$ not added in previous simulant tests.

- Decomposition rates for excess NaTPB in the radioactive tests approximately match rates from simulant testing containing about 10 to 30 times the concentration of total palladium.

- Decomposition rates for (K/Cs)TPB in the radioactive tests approximately match rates from simulant testing containing 150 times the concentration of total palladium.

These findings suggest the following additional investigations.

- Conduct additional radioactive waste tests to examine the reaction rates in systems with inorganic sludge removed.

- Examine the benefit of removal of soluble metals, especially palladium, copper and mercury.

- Measure the relative catalytic influence of selected metals (i.e., W, V, Ce, $\mathrm{Pt}, \mathrm{Rh}$ and Ir) on the decomposition rate of excess NaTPB.

- Examine whether palladium catalyzed decomposition of excess NaTPB increases in the presence of selected metals (e.g., $\mathrm{Hg}, \mathrm{Cd}, \mathrm{Cr}$ and $\mathrm{Mo}$ ).

- Conduct tests with near continuous gas phase benzene measurements and periodic liquid phase soluble boron measurements to confirm accuracy and precision of both analytical methods. 
- Investigate methods to measure the redox potential and oxygen content of reacting systems.

- Develop improved noble metal analyses, and especially palladium, at concentrations of $1-100 \mu \mathrm{g} / \mathrm{L}$ in nominal $5 \mathrm{M}$ sodium solutions.

\subsection{Quality Assurance}

This work used the following task technical plan and quality assurance plans:

M. J. Barnes and D. T. Hobbs, "Task Technical Plan for Radioactive Tests in Support of the In-Tank Precipitation Facility," WSRC-RP-97-0059, revision 1, November 26, 1997.

D. D. Walker and D. T. Hobbs, "Task Quality Assurance Plan for Radioactive Tests in Support of the In-Tank Precipitation Facility," WSRC-RP-97-0060, revision 0, April 18, 1997.

Determination of benzene concentrations in gas samples complied with Interim Waste Technology Section Operating Procedure, "Procedure for Shielded Cells Benzene Measurement (U) [14].

Daily experimental conditions and operations are recorded in the laboratory notebooks WSRC-NB-97-72 and WSRC-NB-97-82. Analytical results and calculations are recorded in laboratory notebooks, WSRC-NB-97-68, WSRC-NB-97-189, WSRC-NB-97-543 and WSRC-NB-98-0059.

All analyses performed by the Analytical Development Section except those using HPLC methods were performed as routine samples and used controls specified by ADS procedures. A control sample consisting of known concentrations of reagent grade NaTPB, 3PB, 2PB, $1 \mathrm{~PB}$ and phenol dissolved in water was submitted with each set of radioactive testing samples. Analytical results for the control sample indicated no corrections are needed over the course of the tests for systematic variances in the responses measured for the control sample. Boron concentrations for samples taken in Batch 2, Test 2U and Test 2A were corrected for boron leaching from the glass reactor using boron leaching rates measured for a salt solution stored in the same type of glass vessels, at the same temperatures and having liquid phase salt concentrations the same the major salt components measured for Batch 2 (see Appendix 9.16 for details).

\subsection{Acknowledgements}

The authors thank the many coworkers from Technical Area Operations and Services, Analytical Development Section, Safety and Health Operations and Waste Processing Technology Section for their contributions and assistance in completing the work reported in this document. Of particular note, the authors acknowledge Sabrina Emory for the lead role in conducting daily Shielded Cells experimental operations, Phyllis Burkhalter for preparation of waste composites, Charles Nash and Ron Blessing for the design, fabrication and installation of the gas measurement system, Gary Dobos and Curt Sexton for fabrication of glassware 
used in the Shielded Cells Facility and Pim Andringa and Steve Peterson for coordination of sample analyses in the Analytical Development Section.

\subsection{References}

1. D. Walker, M. J. Barnes, C. L. Crawford, R. F. Swingle, R. A. Peterson, M. S. Hay and S. D. Fink, "Decomposition of Tetraphenylborate in Tank 48H (U),"WSRC-TR-96-0113, Revision 0, May 1996.

2. Letter from J. T. Conway to H. R. O'Leary, “Defense Nuclear Facilities Safety Board Recommendation 96-1 to the Secretary of Energy," August 14, 1996.

3. Department of Energy Implementation Plan for Defense Nuclear Facilities Safety Board Recommendation 96-1 to the Secretary of Energy, Revision 0, October 1996.

4. E. Marra and J. T. Carter, "Technical Task Request (U), Actual Waste Studies for DNFSB 96-1," HLE-TTR-97014, November 14, 1996.

5. Savannah River Technology Center Procedures Manual, Manual L1, Receipt and Shipment of Radioactive Samples at the 773-A E-Wing Truck Dock, Procedure 2.03, Rev. 1, 12/08/94.

6. Savannah River Technology Center Procedures Manual, Manual L1, Obtaining Analytical Services, Procedure 3.07, Rev. 1, 11/1/94.

7. Procedure Manual L16.1, Analytical Development Section Operating Procedures (U).

8. M. J. Barnes, C. L. Crawford and C. A. Nash, "Sodium Tetraphenylborate Catalyst Identification: Preliminary Studies Set 1 (U)," WSRC-TR-97-0060, revision 0, March 6, 1997.

9. M. J. Barnes and R. A. Peterson, "Sodium Tetraphenylborate Catalyst Identification: Phase A: Statistical Design Studies (U)," WSRC-TR-97-0210, revision 0, July 22, 1997.

10. C. L. Crawford and R. A. Peterson, "Decomposition Studies of Triphenylborane, Diphenylborinic Acid and Phenylboronic Acid in Aqueous Alkaline Solutions Containing Poetential Catalysts," WSRC-TR-97-0225, Rev. 0, July 22, 1997.

11. WSRC 241-82H Control Room Process Requirements (U), WSRC-IM-91-63, revision 18, July 1997.

12. A. Taylor, "Feed Stocks for the Remainder of ITP Cycle 1 (U)," HLW-HLE-97-0046, February, 1997.

13. Procedure for Shielded Cells Benzene Measurement (U), Manual L12.1, Procedure IWTOP-094, revision 2, April 30, 1997. 
14. Gas Chromatograph Operating Procedure (U), L12.1, IWT-OP-005, revision 2, November 15, 1992.

15. J. Barnes and R. A. Peterson, "Sodium Tetraphenylborate Catalyst Identification: Phase A Statistical Design Studies (U)", WSRC-TR-97-0210, Rev. 0, July 22, 1997.

16. M. J. Barnes and R. A. Peterson, "Sodium Tetraphenylborate Catalyst Identification: Phase B and C Statistical Design Studies (U)", WSRC-TR-97-0230, Rev. 0, August 13, 1997.

17. M. J. Barnes, "Sodium Tetraphenylborate Catalyst Identification: Phase D Statistical Design Studies (U)", WSRC-TR-97-0275, Rev. 0, September 5, 1997.

18. "Procedure for Shielded Cells Benzene Measurement (U), Manual L12.1, Procedure IWT-OP-094, revision 2, April 30, 1997.

19. D. J. McCabe, "Cesium, Potassium and Sodium Tetraphenylborate Solubility in Salt Solution," WSRC-TR-96-0384, revision 0, December 16, 1996.

20. M. J. Barnes, R. A. Peterson, R. F. Swingle and C. T. Reeves, "Sodium Tetraphenylborate Solubility and Dissolution Rates," WSRC-TR-95-0092, revision 0, March 7, 1995.

21. S. M. Serkiz and J. D. Ginn, "Tetraphenylborate Solubility in High Ionic Strength Salt Solutions," WSRC-TR-98-00103, March, 1998.

22. J. M. Sullivan, "Use of Hydroxytriphenylborates to Purify Waste Streams," U.S. Patent 5,144,063, September 9, 1992.

23. D. D. Walker, "Benzene Distribution in Product Steams from In-Tank Processing," DPST-86-390, January 15, 1987.

24. D. D. Walker, M. J. Barnes, C. L. Crawford, R. F. Swingle, R. A. Peterson, M. S. Hay and S. D. Fink, "Decomposition of Tetraphenylborate in Tank 48H (U)," WSRC-TR-960113, revision 0, May 10, 1996.

25. J. Barnes, "Sodium Tetraphenylborate Catalyst Identification: Phase D Statistical Design Studies (U), WSRC-TR-97-0274, rev. 0, September 5, 1997. 


\subsection{Appendices}

Appendix 9.1 Composition of Filtered Tank 48H Composite

Appendix 9.2 Composition of Tank 49H Composite

Appendix 9.3 Composition of Tank 25F Composite

Appendix 9.4 Composition of Tank 32H Composite

Appendix 9.5 Composition of Tank 34F Composite

Appendix 9.6 Composition of Tank 39H Composite

Appendix 9.7 Composition of Tank 4F Sludge Sample

Appendix 9.8 Composition of Tank 11H Sludge Sample

Appendix 9.9 Composition of Batch 2 Feed Slurry and Calculated Composition of

Test 2.7 Slurry

Appendix 9.10 Calculated Composition of Tests 3A and 3B Slurries

Appendix 9.11 Calculated Composition of Tests $3 \mathrm{C}$ and 3D Slurries

Appendix 9.12 Calculated Composition of Tests $4 \mathrm{~A}$ and $4 \mathrm{C}$ Slurries

Appendix 9.13 Analytical Data for Batch 2 and Tests 2U, 2A, 2B and 2C

Appendix 9.14 Analytical Data for Tests 3A, 3B, 3C and 3D

Appendix 9.15 Analytical Data for Tests 4A, 4C and 2.7

Appendix 9.16 Radiation Dose Measurements in the SRTC Shielded Cells Facility

Appendix 9.17 Boron Leaching from Glass Vessels

Appendix 9.18 Estimation of Benzene Generation Rate from Appearance of Cs-137 in Filtered Supernatant Liquid 
Appendix 9.1

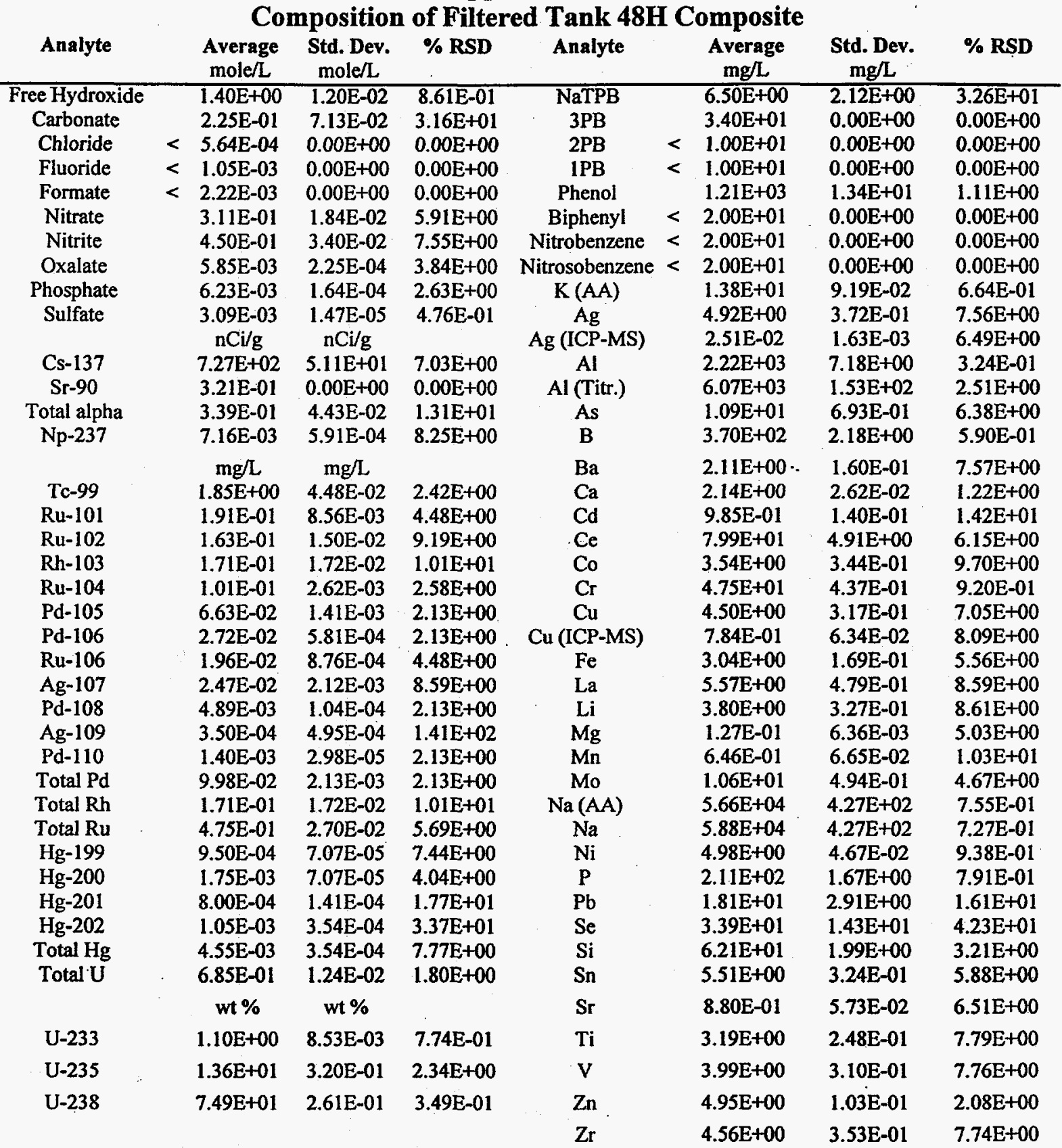


Appendix 9.2

Composition of Tank $49 \mathrm{H}$ Composite

\begin{tabular}{|c|c|c|c|c|c|c|c|c|}
\hline Analyte & & $\begin{array}{c}\text { Average } \\
\text { mole } / \text { L }\end{array}$ & $\begin{array}{c}\text { Std. Dev. } \\
\text { mole/L }\end{array}$ & $\%$ RSD & Analyte & $\begin{array}{c}\text { Average } \\
\mathrm{mg} / \mathrm{L}\end{array}$ & $\begin{array}{l}\text { Std. Dev. } \\
\text { mg/L }\end{array}$ & $\%$ RSD \\
\hline Free Hydroxide & & $7.60 \mathrm{E}-02$ & $1.41 \mathrm{E}-02$ & $1.86 \mathrm{E}+01$ & NaTPB & $3.04 \mathrm{E}+03$ & $3.68 \mathrm{E}+01$ & $1.21 \mathrm{E}+00$ \\
\hline Carbonate & & $9.38 \mathrm{E}-01$ & $1.84 \mathrm{E}-02$ & $1.96 \mathrm{E}+00$ & 3PB & $6.77 \mathrm{E}+02$ & $7.07 \mathrm{E}+00$ & $1.04 \mathrm{E}+00$ \\
\hline Chloride & $<$ & $5.64 \mathrm{E}-04$ & $0.00 \mathrm{E}+00$ & $0.00 \mathrm{E}+00$ & 2PB & $4.85 \mathrm{E}+01$ & $7.07 \mathrm{E}-01$ & $1.46 \mathrm{E}+00$ \\
\hline Fluoride & $<$ & $1.05 \mathrm{E}-03$ & $0.00 \mathrm{E}+00$ & $0.00 E+\infty 0$ & IPB & $3.10 \mathrm{E}+01$ & $7.07 \mathrm{E}+00$ & $2.28 E+01$ \\
\hline Formate & $<$ & $2.22 \mathrm{E}-03$ & $0.00 \mathrm{E}+00$ & $0.00 \mathrm{E}+00$ & Phenol & 4.97E+02 & $3.54 \mathrm{E}+00$ & $7.12 \mathrm{E}-01$ \\
\hline Nitrate & & $5.84 \mathrm{E}-01$ & $3.94 \mathrm{E}-02$ & $6.74 \mathrm{E}+00$ & Biphenyl & $<2.00 \mathrm{E}+01$ & $0.00 \mathrm{E}+00$ & $0.00 \mathrm{E}+00$ \\
\hline Nitrite & & $9.08 \mathrm{E}-01$ & $5.65 \mathrm{E}-02$ & $6.22 \mathrm{E}+00$ & Nitrobenzene & $<2.00 \mathrm{E}+01$ & $0.00 \mathrm{E}+00$ & $0.00 \mathrm{E}+00$ \\
\hline Oxalate & & $8.36 \mathrm{E}-03$ & $4.82 \mathrm{E}-05$ & $5.76 \mathrm{E}-01$ & Nitrosobenzene & $<2.00 \mathrm{E}+01$ & $0.00 \mathrm{E}+00$ & $0.00 \mathrm{E}+00$ \\
\hline Phosphate & & $1.15 \mathrm{E}-03$ & $1.41 \mathrm{E}-04$ & $1.23 \mathrm{E}+01$ & $\mathrm{~K}(\mathrm{AA})$ & $<1.95 \mathrm{E}-01$ & $0.00 \mathrm{E}+00$ & $0.00 \mathrm{E}+00$ \\
\hline Sulfate & & $3.43 \mathrm{E}-02$ & $1.66 \mathrm{E}-03$ & $4.85 E+00$ & $\mathrm{Ag}$ & $3.85 \mathrm{E}+00$ & 8.85E-01 & $2.30 \mathrm{E}+01$ \\
\hline & & $\mathrm{nCi} / \mathrm{g}$ & $\mathrm{nCi} / \mathrm{g}$ & & $\mathrm{Ag}$ (ICP-MS) & 1.37E-02 & $7.42 \mathrm{E}-03$ & $5.44 \mathrm{E}+01$ \\
\hline Cs-137 & & $2.79 \mathrm{E}+01$ & $2.99 \mathrm{E}-01$ & $1.08 \mathrm{E}+00$ & $\mathrm{Al}$ & $1.48 \mathrm{E}+03$ & $6.48 \mathrm{E}+00$ & $4.39 \mathrm{E}-01$ \\
\hline Sr-90 & $<$ & $1.93 \mathrm{E}-01$ & $0.00 \mathrm{E}+00$ & $0.00 \mathrm{E}+00$ & $\mathrm{Al}$ (Titr.) & $1.25 \mathrm{E}+03$ & $1.90 \mathrm{E}+01$ & $1.52 \mathrm{E}+00$ \\
\hline Total alpha & & 4.33E-01 & $1.91 \mathrm{E}-02$ & $4.40 \mathrm{E}+00$ & As & $1.47 \mathrm{E}+01$ & $1.43 \mathrm{E}+00$ & $9.69 \mathrm{E}+00$ \\
\hline $\mathrm{Np}-237$ & & $0.00 \mathrm{E}+00$ & $.0 .00 \mathrm{E}+00$ & & B & $1.87 \mathrm{E}+02$ & $8.00 \mathrm{E}-01$ & $4.27 \mathrm{E}-01$ \\
\hline & & $\mathrm{mg} / \mathrm{L}$ & $\mathrm{mg} / \mathrm{L}$ & & $\mathrm{Ba}$ & $1.63 E+00$ & $3.75 \mathrm{E}-01$ & $2.30 \mathrm{E}+01$ \\
\hline Tc-99 & & $5.93 \mathrm{E}-01$ & $1.29 \mathrm{E}-01$ & $2.18 \mathrm{E}+01$ & $\mathrm{Ca}$ & $1.26 \mathrm{E}+00$ & $1.13 \mathrm{E}-02$ & $9.00 \mathrm{E}-01$ \\
\hline Ru-101 & & $7.46 \mathrm{E}-02$ & $1.36 \mathrm{E}-02$ & $1.83 E+01$ & $\mathrm{Cd}$ & $1.02 \mathrm{E}+00$ & $1.32 \mathrm{E}-01$ & $1.29 \mathrm{E}+01$ \\
\hline $\mathbf{R u}-102$ & & $6.66 \mathrm{E}-02$ & $1.39 \mathrm{E}-02$ & $2.09 \mathrm{E}+01$ & $\mathrm{Ce}$ & $6.65 \mathrm{E}+01$ & $1.29 \mathrm{E}+01$ & $1.95 \mathrm{E}+01$ \\
\hline Rh-103 & & $1.03 \mathrm{E}-01$ & $3.10 \mathrm{E}-02$ & $3.01 \mathrm{E}+01$ & Co & $3.29 \mathrm{E}+00$ & 7.47E-01 & $2.27 \mathrm{E}+01$ \\
\hline Ru-104 & & $3.59 \mathrm{E}-02$ & $3.11 \mathrm{E}-03$ & $8.67 \mathrm{E}+00$ & $\mathrm{Cr}$ & $8.37 \mathrm{E}+00$ & $5.42 \mathrm{E}-01$ & $6.48 \mathrm{E}+00$ \\
\hline $\mathrm{Pd}-105$ & & 2.45E-02 & $5.80 \mathrm{E}-03$ & $2.37 \mathrm{E}+01$ & $\mathrm{Cu}$ & $3.42 \mathrm{E}+00$ & $7.42 \mathrm{E}-01$ & $2.17 E+01$ \\
\hline Pd-106 & & $1.01 \mathrm{E}-02$ & $2.38 \mathrm{E}-03$ & $2.37 \mathrm{E}+01$ & $\mathrm{Cu}$ (ICP-MS) & $5.88 \mathrm{E}-01$ & $9.80 \mathrm{E}-02$ & $1.67 E+01$ \\
\hline Ru-106 & & 7.63E-03 & $1.40 \mathrm{E}-03$ & $1.83 \mathrm{E}+01$ & $\mathrm{Fe}$ & $3.01 E+00$ & $4.41 \mathrm{E}-01$ & $1.47 \mathrm{E}+01$ \\
\hline $\mathrm{Ag}-107$ & & $1.09 \mathrm{E}-02$ & $3.54 \mathrm{E}-03$ & $3.24 E+01$ & $\mathrm{La}$ & $5.11 \mathrm{E}+00$ & $1.91 E+00$ & $3.75 \mathrm{E}+01$ \\
\hline Pd-108 & & $1.81 \mathrm{E}-03$ & $4.27 \mathrm{E}-04$ & $2.37 \mathrm{E}+01$ & $\mathrm{Li}$ & $2.89 \mathrm{E}+00$ & $5.83 \mathrm{E}-01$ & $2.02 E+01$ \\
\hline $\mathrm{Ag}-109$ & & $2.75 \mathrm{E}-03$ & $3.89 \mathrm{E}-03$ & $1.41 \mathrm{E}+02$ & $\mathbf{M g}$ & $9.15 \mathrm{E}-02$ & $6.36 \mathrm{E}-03$ & $6.96 \mathrm{E}+00$ \\
\hline Pd-110 & & $5.16 \mathrm{E}-04$ & $1.22 \mathrm{E}-04$ & $2.37 E+01$ & Mn & $5.93 \mathrm{E}-01$ & $1.22 \mathrm{E}-01$ & $2.06 \mathrm{E}+01$ \\
\hline Total Pd & & $3.69 \mathrm{E}-02$ & 8.73 & $2.37 \mathrm{E}+01$ & Mo & $E+00$ & $4.28 \mathrm{E}-01$ & $6.53 \mathrm{E}+00$ \\
\hline Total $\mathbf{R h}$ & & $1.03 \mathrm{E}-01$ & $3.10 \mathrm{E}-02$ & $3.01 \mathrm{E}+0.1$ & $\mathrm{Na}(\mathrm{AA})$ & $7.97 E+04$ & $1.02 \mathrm{E}+03$ & $1.29 \mathrm{E}+00$ \\
\hline Total Ru & & $1.85 \mathrm{E}-01$ & $3.21 \mathrm{E}-02$ & $1.74 \mathrm{E}+01$ & $\mathrm{Na}$. & $8.34 \mathrm{E}+04$ & $1.21 \mathrm{E}+02$ & $1.45 \mathrm{E}-01$ \\
\hline $\mathrm{Hg}-199$ & & $7.10 \mathrm{E}-03$ & $1.13 \mathrm{E}-03$ & $1.59 \mathrm{E}+01$ & $\mathrm{Ni}$ & $4.96 \mathrm{E}+00$ & $1.08 E+00$ & $2.18 \mathrm{E}+01$ \\
\hline Hg-200 & & $9.20 \mathrm{E}-03$ & $1.56 \mathrm{E}-03$ & $1.69 \mathrm{E}+01$ & $\mathbf{P}$ & $5.54 \mathrm{E}+01$ & $1.47 \mathrm{E}+00$ & $2.65 \mathrm{E}+00$ \\
\hline $\mathrm{Hg}-201$ & & $4.85 \mathrm{E}-03$ & $6.36 \mathrm{E}-04$ & $1.31 \mathrm{E}+01$ & $\mathrm{~Pb}$ & $1.59 \mathrm{E}+01$ & $3.24 E+00$ & $2.05 E+01$ \\
\hline $\mathrm{Hg}-202$ & & $1.06 \mathrm{E}-02$ & $1.27 \mathrm{E}-03$ & $1.20 \mathrm{E}+01$ & $\mathrm{Se}$ & $3.90 E+01$ & $1.00 \mathrm{E}+01$ & $2.58 \mathrm{E}+01$ \\
\hline Total $\mathrm{Hg}$ & & $3.18 \mathrm{E}-02$ & $4.60 \mathrm{E}-03$ & $1.45 \mathrm{E}+01$ & $\mathbf{S i}$ & $2.25 \mathrm{E}+01$ & 4.49E+00 & $2.00 \mathrm{E}+01$ \\
\hline $\mathrm{Hg}(\mathrm{AA})$ & $<$ & $1.00 \mathrm{E}-01$ & $0.00 \mathrm{E}+00$ & $0.00 E+00$ & Sn & $9.04 \mathrm{E}+00$ & $9.52 \mathrm{E}-01$ & $1.05 E+01$ \\
\hline Total U & & $2.20 \mathrm{E}-01$ & $3.80 \mathrm{E}-02$ & $1.73 \mathrm{E}+01$ & $\mathrm{Sr}$ & $8.79 \mathrm{E}-01$ & $1.42 \mathrm{E}-01$ & $1.62 E+01$ \\
\hline & & & & & 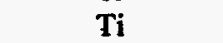 & $2.64 \mathrm{E}+00$ & $5.42 \mathrm{E}-01$ & $2.06 \mathrm{E}+01$ \\
\hline U-233 & & 1.57E+00 & $5.58 \mathrm{E}-02$ & $3.55 \mathrm{E}+00$ & v & $3.05 E+00$ & $.7 .03 \mathrm{E}-01$ & $2.31 \mathrm{E}+01$ \\
\hline U-235 & & $1.48 \mathrm{E}+01$ & $1.11 \mathrm{E}+00$ & $7.50 \mathrm{E}+00$ & $\mathrm{Zn}$ & $1.45 \mathrm{E}+00$ & $2.67 \mathrm{E}-01$ & $1.84 \mathrm{E}+01$ \\
\hline U-238 & & $8.15 E+01$ & $1.06 \mathrm{E}+00$ & $1.30 \mathrm{E}+00$ & $\mathrm{Zr}$ & $3.72 E+00$ & $8.12 \mathrm{E}-01$ & $2.18 \mathrm{E}+01$ \\
\hline
\end{tabular}


Appendix 9.3

Composition of Tank 25F Composite

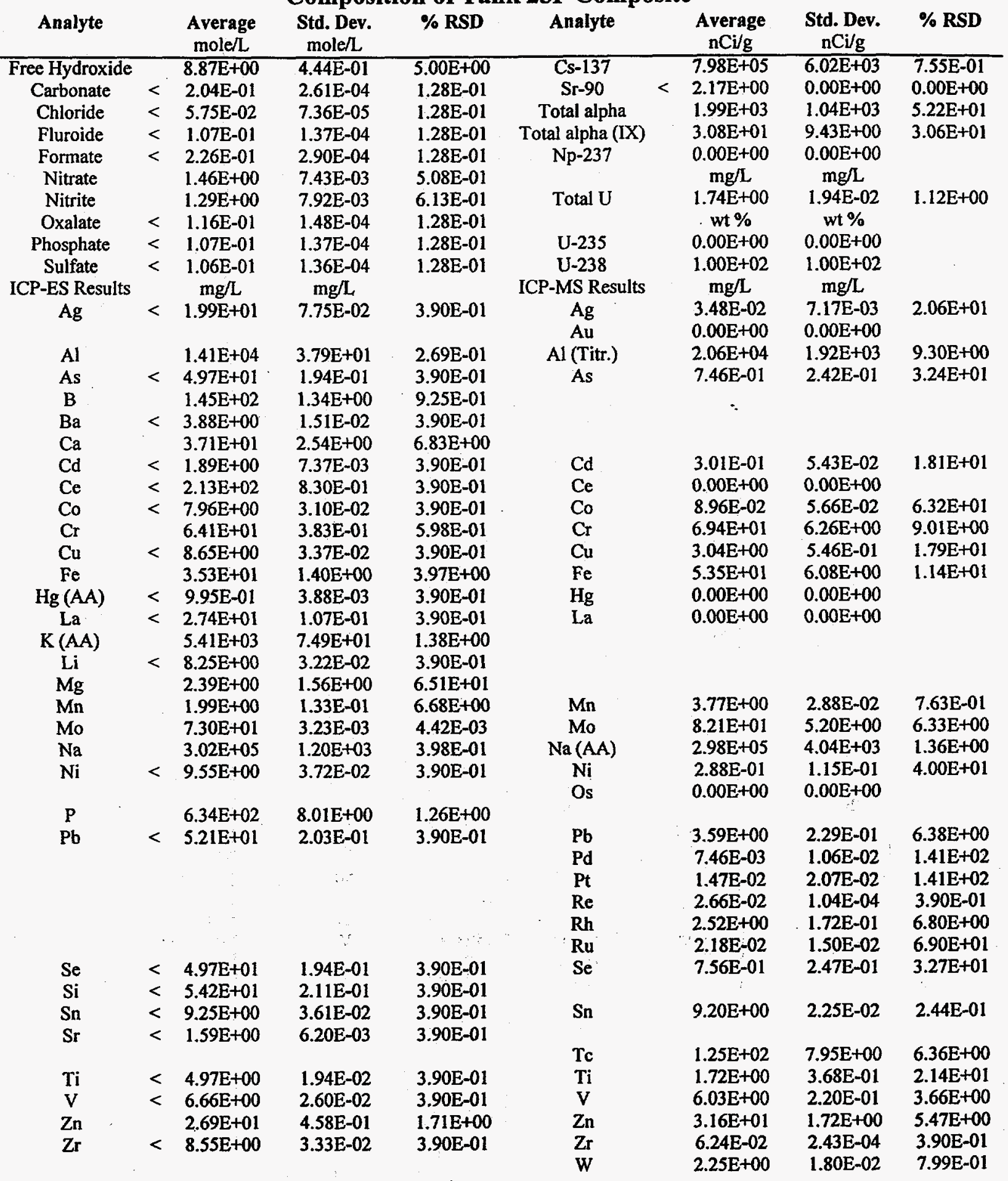


Appendix 9.4

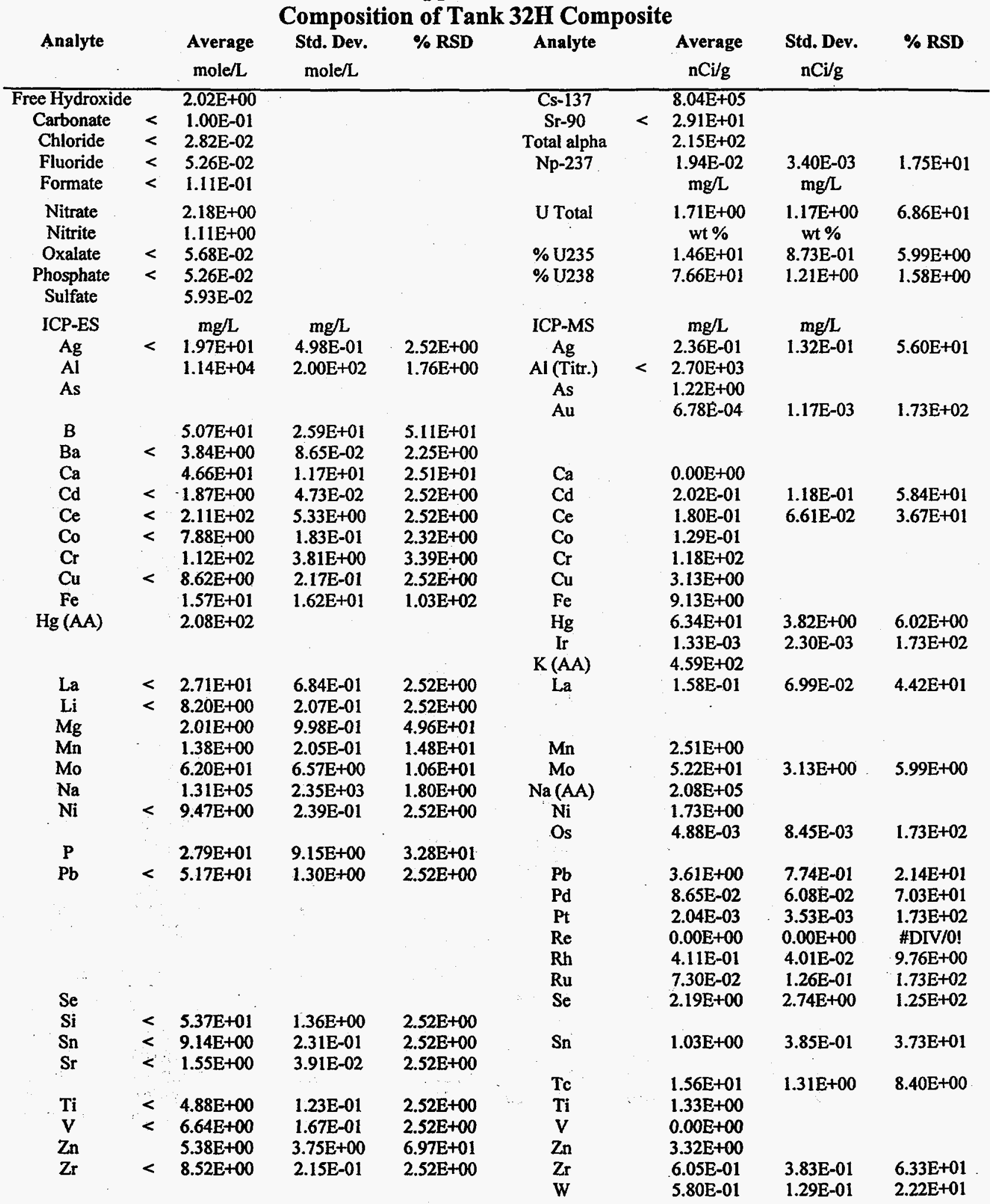


Appendix 9.5

\begin{tabular}{|c|c|c|c|c|c|c|c|c|}
\hline \multicolumn{9}{|c|}{ Composition of Tank 34F Composite } \\
\hline Analyte & & $\begin{array}{c}\text { Average } \\
\text { mole/L }\end{array}$ & $\begin{array}{l}\text { Std. Dev. } \\
\text { mole/L }\end{array}$ & $\begin{array}{l}\% \text { RSD } \\
\text { mole/l }\end{array}$ & Analyte & $\begin{array}{c}\text { Average } \\
\mathrm{nCi} / \mathrm{g}\end{array}$ & $\begin{array}{l}\text { Std. Dev. } \\
\mathrm{nCi} / \mathrm{g}\end{array}$ & \% RSD \\
\hline Free Hydroxide & & $5.10 \mathrm{E}+00$ & $3.43 \mathrm{E}-02$ & $6.73 \mathrm{E}-01$ & $\overline{C s-137}$ & $6.30 \mathrm{E}+05$ & $6.70 \mathrm{E}+03$ & $1.06 \mathrm{E}+00$ \\
\hline Carbonate & $<$ & $2.00 \mathrm{E}-01$ & $1.62 \mathrm{E}-03$ & $8.12 \mathrm{E}-01$ & $\mathrm{Sr}-90$ & $1.14 \mathrm{E}-01$ & $2.31 \mathrm{E}-02$ & $2.02 \mathrm{E}+01$ \\
\hline Chloride & $<$ & $6.06 \mathrm{E}-02$ & $5.49 \mathrm{E}-03$ & $9.06 \mathrm{E}+00$ & Total alpha & $1.22 \mathrm{E}+02$ & $8.79 E+01$ & $7.18 \mathrm{E}+01$ \\
\hline F- & $<$ & $1.05 \mathrm{E}-01$ & $8.55 \mathrm{E}-04$ & $8.12 \mathrm{E}-01$ & Np-237 & $2.58 \mathrm{E}-03$ & $1.04 \mathrm{E}-03$ & $4.04 E+01$ \\
\hline $\mathrm{HCOO}-$ & $<$ & $2.22 \mathrm{E}-01$ & $1.80 \mathrm{E}-03$ & $8.12 \mathrm{E}-01$ & & & & \\
\hline NO3- & & $2.51 \mathrm{E}+00$ & 4.12E-02 & $1.65 \mathrm{E}+00$ & & $\mathrm{mg} / \mathrm{L}$ & $\mathrm{mg} / \mathrm{L}$ & \\
\hline NO2- & & $8.71 \mathrm{E}-01$ & $3.01 \mathrm{E}-02$ & $3.46 \mathrm{E}+00$ & Total U & $9.65 \mathrm{E}+00$ & $8.92 \mathrm{E}-01$ & $9.24 \mathrm{E}+00$ \\
\hline C2O4-- & $<$ & $1.14 \mathrm{E}-01$ & $9.23 \mathrm{E}-04$ & $8.12 \mathrm{E}-01$ & & wt \% & wt \% & \\
\hline PO4--- & $<$ & $1.05 \mathrm{E}-01$ & $8.55 \mathrm{E}-04$ & 8.12E-01 & U-235 & $3.11 \mathrm{E}-01$ & $1.50 \mathrm{E}-02$ & $4.84 \mathrm{E}+00$ \\
\hline $\begin{array}{l}\text { SO4- } \\
\text { ICP-ES }\end{array}$ & $<$ & $\begin{array}{c}1.04 \mathrm{E}-01 \\
\mathrm{mg} / \mathrm{L}\end{array}$ & $\begin{array}{c}\text { 8.45E-04 } \\
\mathrm{mg} / \mathrm{L}\end{array}$ & $8.12 \mathrm{E}-01$ & $\begin{array}{l}\text { U-238 } \\
\text { ICP-MS }\end{array}$ & $\begin{array}{c}9.97 \mathrm{E}+01 \\
\mathrm{mg} / \mathrm{L}\end{array}$ & $\begin{array}{c}7.06 \mathrm{E}-03 \\
\mathrm{mg} / \mathrm{L}\end{array}$ & $7.09 \mathrm{E}-03$ \\
\hline $\mathrm{Ag}$ & & $1.99 \mathrm{E}+01$ & $5.81 \mathrm{E}-02$ & $2.92 \mathrm{E}-01$ & $\mathrm{Ag}$ & 2.15E-02 & $1.90 \mathrm{E}-02$ & $8.85 \mathrm{E}+01$ \\
\hline $\mathrm{Al}$ & & $8.23 E+03$ & $2.08 \mathrm{E}+01$ & $2.53 \mathrm{E}-01$ & Al (Titr.) & $5.39 \mathrm{E}+03$ & 4.37E+01 & $8.12 \mathrm{E}-01$ \\
\hline As & & & & & As & $5.56 \mathrm{E}-01$ & 1.17E-02 & $2.11 \mathrm{E}+00$ \\
\hline & & & & & $\mathrm{Au}$ & $0.00 \mathrm{E}+00$ & $0.00 \mathrm{E}+00$ & \\
\hline B & & $2.40 \mathrm{E}+02$ & 3.48E-01 & $1.45 \mathrm{E}-01$ & & $\therefore$ & & \\
\hline $\mathrm{Ba}$ & & $4.62 \mathrm{E}+00$ & $1.06 \mathrm{E}+00$ & $2.29 \mathrm{E}+01$ & & & & \\
\hline $\mathrm{Ca}$ & & $4.04 \mathrm{E}+01$ & $3.43 \mathrm{E}+00$ & $8.49 \mathrm{E}+00$ & $\mathrm{Ca}$ & $3.56 \mathrm{E}+01$ & $3.79 \mathrm{E}+00$ & $1.06 \mathrm{E}+01$ \\
\hline $\mathrm{Cd}$ & & $2.44 \mathrm{E}+00$ & 7.67E-01 & $3.15 \mathrm{E}+01$ & & & & \\
\hline $\mathrm{Ce}$ & & & & & $\mathrm{Ce}$ & $1.23 \mathrm{E}-02$ & $4.90 \mathrm{E}-03$ & $3.98 \mathrm{E}+01$ \\
\hline Co & & $7.93 \mathrm{E}+00$ & $2.32 \mathrm{E}-02$ & 2.92E-01 & Co & $3.46 \mathrm{E}-02$ & $2.90 \mathrm{E}-02$ & $8.39 \mathrm{E}+01$ \\
\hline $\mathrm{Cr}$ & & $2.07 \mathrm{E}+02$ & $6.75 \mathrm{E}-01$ & $3.26 \mathrm{E}-01$ & $\mathrm{Cr}$ & $2.35 \mathrm{E}+02$ & $2.32 \mathrm{E}+01$ & $9.87 \mathrm{E}+00$ \\
\hline $\mathrm{Cu}$ & & $1.01 \mathrm{E}+01$ & $1.98 \mathrm{E}+00$ & $1.96 \mathrm{E}+01$ & $\mathrm{Cu}$ & $5.54 \mathrm{E}+01$ & $1.46 \mathrm{E}+01$ & $2.63 E+01$ \\
\hline $\mathrm{Fe}$ & & $5.56 \mathrm{E}+01$ & $2.40 \mathrm{E}+01$ & $4.32 \mathrm{E}+01$ & $\mathrm{Fe}$ & $0.00 \mathrm{E}+00$ & $0.00 \mathrm{E}+00$ & \\
\hline $\mathrm{Hg}(\mathrm{AA})$ & & $1.42 \mathrm{E}+01$ & $5.21 \mathrm{E}-01$ & $3.66 \mathrm{E}+00$ & $\mathrm{Hg}$ & $1.52 \mathrm{E}+00$ & 6.77E-01 & $4.45 \mathrm{E}+01$ \\
\hline & & & & & Ir & $0.00 \mathrm{E}+00$ & $0.00 \mathrm{E}+00$ & \\
\hline$K(\mathrm{AA})$ & & $2.23 \mathrm{E}+03$ & $1.57 \mathrm{E}+01$ & 7.02E-01 & & & & \\
\hline La & & & & & $\mathrm{La}$ & 4.13E-02 & $2.30 \mathrm{E}-02$ & $5.57 \mathrm{E}+01$ \\
\hline $\mathrm{La}$ & & $\begin{array}{l}2.74 \mathrm{E}+01 \\
8.28 \mathrm{E}+00\end{array}$ & $\begin{array}{l}7.99 \mathrm{E}-02 \\
2.42 \mathrm{E}-02\end{array}$ & $\begin{array}{l}2.92 \mathrm{E}-01 \\
2.92 \mathrm{E}-01\end{array}$ & & & & \\
\hline $\mathrm{Mg}$ & & $5.67 \mathrm{E}+00$ & $1.99 \mathrm{E}+00$ & $\begin{array}{l}2.92 \mathrm{E}-01 \\
3.50 \mathrm{E}+01\end{array}$ & & & & \\
\hline $\mathrm{Mn}$ & & $1.24 \mathrm{E}+00$ & $3.63 \mathrm{E}-03$ & $2.92 \mathrm{E}-01$ & Mn & 4.95E-01 & $1.66 \mathrm{E}-01$ & $3.35 \mathrm{E}+01$ \\
\hline Mo & & $5.90 \mathrm{E}+01$ & $4.47 \mathrm{E}+00$ & $7.58 \mathrm{E}+00$ & Mo & $4.90 \mathrm{E}+01$ & $5.23 \mathrm{E}+00$ & $1.07 E+01$ \\
\hline $\mathrm{Na}$ & & $2.44 \mathrm{E}+05$ & $1.89 \mathrm{E}+03$ & $7.74 \mathrm{E}-01$ & $\mathrm{Na}(\mathrm{Na})$ & $2.08 \mathrm{E}+05$ & $1.15 \mathrm{E}+03$ & $5.52 \mathrm{E}-01$ \\
\hline $\mathrm{Ni}$ & & $1.13 E+01$ & $2.43 E+00$ & $2.15 \mathrm{E}+01$ & $\mathrm{Ni}$ & $4.23 \mathrm{E}+0 \mathrm{I}$ & $9.90 \mathrm{E}+00$ & $2.34 \mathrm{E}+01$ \\
\hline & & & & & Os & $0.00 \mathrm{E}+00$ & $0.00 \mathrm{E}+00$ & \\
\hline $\mathbf{P}$ & & $3.66 \mathrm{E}+02$ & $1.02 \mathrm{E}+02$ & $2.78 \mathrm{E}+01$ & $\mathbf{P b}$ & $2.74 \mathrm{E}+00$ & 2.54E-01 & $9.29 \mathrm{E}+00$ \\
\hline $\mathrm{Pb}$ & & $5.21 \mathrm{E}+01$ & $1.52 \mathrm{E}-01$ & 2.92E-01 & & & & \\
\hline & & & & & $\begin{array}{l}\mathrm{Pt} \\
\mathrm{Re}\end{array}$ & $\begin{array}{l}1.25 \mathrm{E}-02 \\
8.64 \mathrm{E}-03\end{array}$ & $\begin{array}{l}2.86 \mathrm{E}-03 \\
128 \mathrm{E}-03\end{array}$ & $\begin{array}{l}2.28 E+01 \\
1.49 E+01\end{array}$ \\
\hline $\mathrm{Se}$ & & & & & Se & $1.11 \mathrm{E}+01$ & $1.41 \mathrm{E}+00$ & $1.27 \mathrm{E}+01$ \\
\hline $\mathrm{Si}$ & & $8.76 \mathrm{E}+01$ & $2.66 \mathrm{E}+01$ & $3.03 \mathrm{E}+01$ & & & & \\
\hline Sn & & $9.44 \mathrm{E}+00$ & $2.75 \mathrm{E}-01$ & $2.91 \mathrm{E}+00$ & Sn & $3.82 \mathrm{E}+00$ & $2.86 \mathrm{E}-01$ & $7.49 \mathrm{E}+00$ \\
\hline $\mathrm{Sr}$ & & $1.88 \mathrm{E}+00$ & 4.38E-01 & $2.33 \mathrm{E}+01$ & & & & \\
\hline & & & & & Tc & $8.88 \mathrm{E}+00$ & 8.40E-01 & $9.46 \mathrm{E}+00$ \\
\hline $\mathrm{Ti}$ & & $7.09 \mathrm{E}+00$ & $3.04 \mathrm{E}+00$ & $4.29 \mathrm{E}+01$ & $\mathrm{Ti}$ & $1.28 \mathrm{E}+01$ & $1.98 \mathrm{E}+00$ & $1.55 \mathrm{E}+01$ \\
\hline V & & $9.81 \mathrm{E}+00$ & $4.38 \mathrm{E}+00$ & $4.47 \mathrm{E}+01$ & V & $4.01 \mathrm{E}+00$ & 4.52E-01 & $1.13 E+01$ \\
\hline $\mathrm{Zn}$ & & $2.66 \mathrm{E}+01$ & $7.67 \mathrm{E}-01$ & $2.89 \mathrm{E}+00$ & $\mathrm{Zn}$ & $1.36 \mathrm{E}+01$ & $2.47 \mathrm{E}+00$ & $1.82 E+01$ \\
\hline $\mathrm{Zr}$ & & $1.17 \mathrm{E}+01$ & $4.37 \mathrm{E}+00$ & $3.73 \mathrm{E}+01$ & $\mathrm{Zr}$ & $2.28 \mathrm{E}-01$ & 4.95E-02 & $2.17 E+01$ \\
\hline & & & & & W & $1.83 E+00$ & $2.55 \mathrm{E}-01$ & $1.39 \mathrm{E}+01$ \\
\hline
\end{tabular}




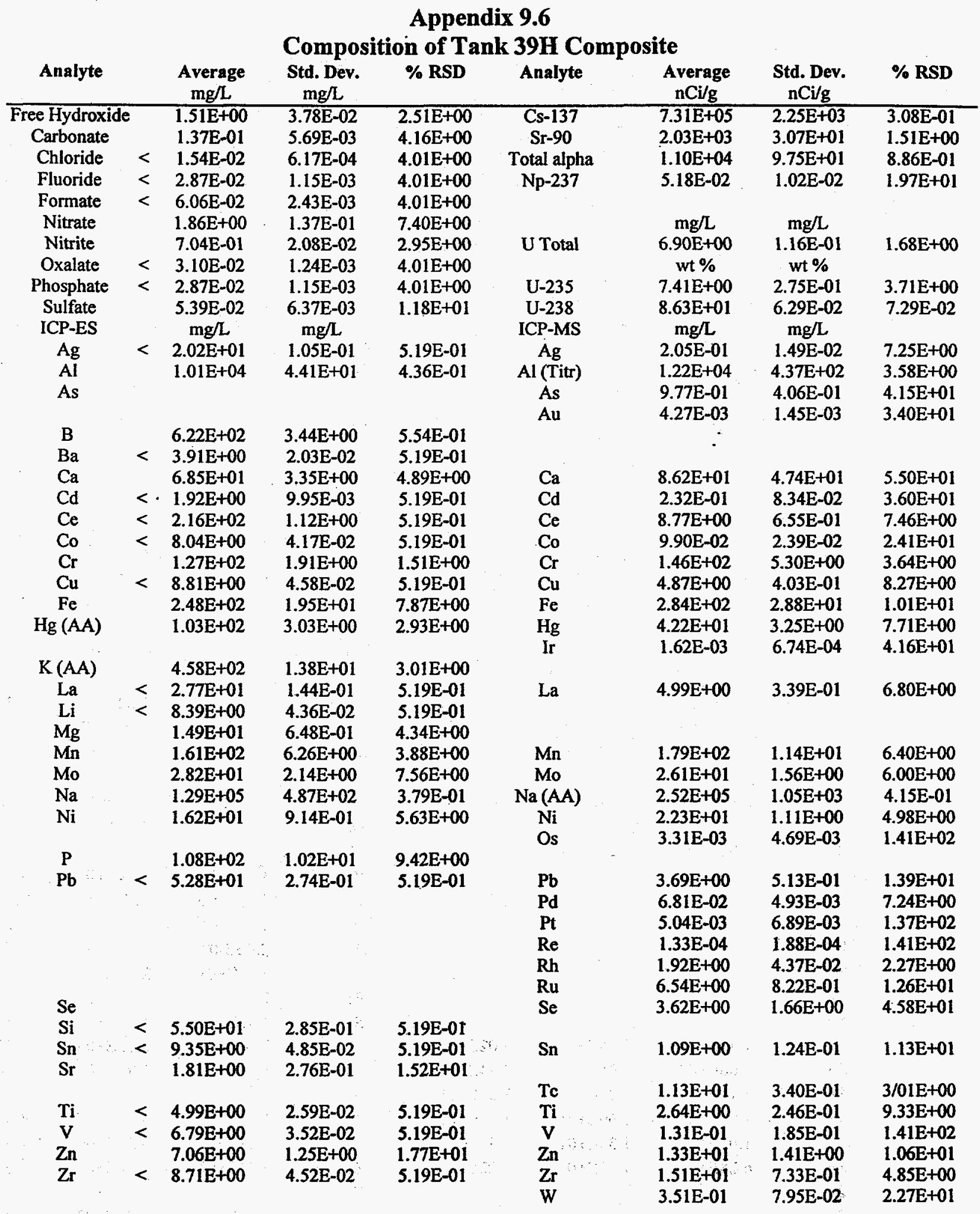


Appendix 9.7

Composition of Tank 4F Sludge Sample

\begin{tabular}{|c|c|c|c|c|c|c|c|}
\hline Analyte & $\begin{array}{c}\text { Average } \\
\mathrm{nCi} / \mathrm{g}\end{array}$ & $\begin{array}{c}\text { Std. Dev. } \\
\text { nCi } / \mathrm{g}\end{array}$ & $\%$ RSD & Analyte & $\begin{array}{c}\text { Average } \\
\mathrm{nCi} / \mathrm{g}\end{array}$ & $\begin{array}{c}\text { Std. Dev. } \\
\text { nCi/g }\end{array}$ & \%RSD \\
\hline Cs-137 & $7.94 \mathrm{E}+05$ & $3.07 \mathrm{E}+05$ & $3.87 \mathrm{E}+01$ & Alpha total & $5.20 \mathrm{E}+04$ & $2.75 E+04$ & $5.28 \mathrm{E}+01$ \\
\hline Am-241 & $1.26 \mathrm{E}+04$ & $5.16 \mathrm{E}+03$ & $4.11 \mathrm{E}+01$ & $\mathrm{Pu}-239 / 240$ & $0.00 \mathrm{E}+00$ & $0.00 \mathrm{E}+00$ & \\
\hline Eu-154 & $9.01 E+03$ & $3.94 \mathrm{E}+03$ & $4.37 \mathrm{E}+01$ & $\mathrm{Pu}-238 / 241$ & $1.44 \mathrm{E}+04$ & $6.23 E+03$ & $4.34 \mathrm{E}+01$ \\
\hline Eu-155 & $1.15 E+04$ & $5.52 \mathrm{E}+03$ & $4.80 \mathrm{E}+01$ & $\mathrm{Cm}-244$ & $3.76 \mathrm{E}+04$ & $2.12 E+04$ & $5.65 \mathrm{E}+01$ \\
\hline Co-60 & $4.71 E+03$ & $2.92 \mathrm{E}+03$ & $6.19 \mathrm{E}+01$ & Sr-90 & $0.00 \mathrm{E}+00$ & $0.00 \mathrm{E}+00$ & \\
\hline ICP-ES & $\mu \mathrm{g} / \mathrm{g}$ & $\mu \mathrm{g} / \mathrm{g}$ & & ICP-MS & $\mu \mathrm{g} / \mathrm{g}$ & $\mu \mathrm{g} / \mathrm{g}$ & \\
\hline $\mathrm{Ag}$ & & & & $\mathrm{Ag}$ & $7.47 \mathrm{E}+01$ & $7.17 \mathrm{E}+00$ & $9.60 \mathrm{E}+00$ \\
\hline As & & & & As & $2.82 \mathrm{E}+01$ & 6.67E-01 & $2.37 \mathrm{E}+00$ \\
\hline $\mathrm{Al}$ & $8.00 \mathrm{E}+03$ & $2.77 \mathrm{E}+03$ & $3.46 \mathrm{E}+01$ & $\mathrm{Al}$ & $8.00 \mathrm{E}+03$ & $2.77 \mathrm{E}+03$ & $3.46 \mathrm{E}+01$ \\
\hline $\mathrm{Au}$ & & & & $\mathrm{Au}$ & $3.46 \mathrm{E}-01$ & $3.86 \mathrm{E}-01$ & $1.12 \mathrm{E}+02$ \\
\hline B & & & & B & & & \\
\hline $\mathbf{B a}$ & $1.58 \mathrm{E}+02$ & $5.76 \mathrm{E}+01$ & $3.66 \mathrm{E}+01$ & $\mathrm{Ba}$ & & & \\
\hline $\mathrm{Ca}$ & $1.64 \mathrm{E}+03$ & $1.57 \mathrm{E}+02$ & $9.58 \mathrm{E}+00$ & $\mathrm{Ca}$ & $1.92 \mathrm{E}+03=$ & $3.87 \mathrm{E}+02$ & $2.02 \mathrm{E}+01$ \\
\hline $\mathrm{Cd}$ & $3.71 \mathrm{E}+01$ & $6.40 \mathrm{E}+00$ & $1.72 E+01$ & $\mathrm{Cd}$ & $1.72 \mathrm{E}+01$ & $7.20 \mathrm{E}-01$ & 4.19E+00 \\
\hline $\mathrm{Ce}$ & & & & $\mathrm{Ce}$ & $7.66 \mathrm{E}+01$ & $3.57 \mathrm{E}+01$ & $4.66 \mathrm{E}+01$ \\
\hline Co & & & & Co & $1.37 \mathrm{E}+01$ & $7.74 \mathrm{E}+00$ & $5.65 \mathrm{E}+01$ \\
\hline $\mathrm{Cr}$ & $1.08 \mathrm{E}+03$ & $3.15 E+02$ & $2.91 \mathrm{E}+01$ & $\mathrm{Cr}$ & $1.53 \mathrm{E}+02$ & $7.99 \mathrm{E}+00$ & $5.22 \mathrm{E}+00$ \\
\hline $\mathrm{Cu}$ & $2.05 E+02$ & $4.93 E+01$ & $2.40 \mathrm{E}+01$ & $\mathrm{Cu}$ & $3.27 \mathrm{E}+02$ & $1.32 \mathrm{E}+02$ & $4.04 E+01$ \\
\hline $\mathrm{Fe}$ & $2.85 E+04$ & $1.26 \mathrm{E}+04$ & $4.41 \mathrm{E}+01$ & $\mathrm{Fe}$ & $1.80 \mathrm{E}+05$ & $9.87 \mathrm{E}+03$ & $5.48 \mathrm{E}+00$ \\
\hline $\mathrm{Hg}$ & & & & $\mathrm{Hg}$ & $5.13 \mathrm{E}+00$ & $3.44 \mathrm{E}+00$ & $6.71 E+01$ \\
\hline Ir & & & & Ir & $3.50 \mathrm{E}-02$ & $1.65 \mathrm{E}-02$ & $4.71 E+01$ \\
\hline $\mathbf{L a}$ & & & & $\mathrm{La}$ & $4.04 \mathrm{E}+01$ & $2.06 \mathrm{E}+01$ & $5.10 \mathrm{E}+01$ \\
\hline $\mathrm{Li}$ & $1.46 \mathrm{E}+02$ & $2.24 \mathrm{E}+01$ & $1.53 E+01$ & $\mathrm{Li}$ & & & \\
\hline $\mathrm{Mg}$ & $2.97 \mathrm{E}+03$ & $3.82 E+02$ & $1.28 \mathrm{E}+01$ & Mg & $2.97 \mathrm{E}+03$ & $3.82 \mathrm{E}+02$ & $1.29 \mathrm{E}+01$ \\
\hline Mn & $1.51 E+03$ & $6.59 \mathrm{E}+02$ & $4.37 \mathrm{E}+01$ & $\mathrm{Mn}$ & $1.15 E+03$ & $6.11 \mathrm{E}+02$ & $5.31 \mathrm{E}+01$ \\
\hline Mo & $9.01 \mathrm{E}+01$ & $5.19 \mathrm{E}+01$ & $5.76 \mathrm{E}+01$ & Mo & $1.57 \mathrm{E}+01$ & $6.41 \mathrm{E}+00$ & $4.08 \mathrm{E}+01$ \\
\hline $\mathrm{Na}$ & & & & $\mathrm{Na}$ & & & \\
\hline $\mathrm{Ni}$ & $5.96 \mathrm{E}+03$ & $2.64 \mathrm{E}+03$ & $4.42 \mathrm{E}+01$ & $\mathrm{Ni}$ & $2.88 \mathrm{E}+03$ & $1.55 \mathrm{E}+03$ & $5.38 \mathrm{E}+01$ \\
\hline Os & & & & Os & $3.48 \mathrm{E}-02$ & $4.93 \mathrm{E}-02$ & $1.42 \mathrm{E}+02$ \\
\hline $\mathbf{P}$ & $1.06 \mathrm{E}+03$ & $2.29 \mathrm{E}+02$ & $2.15 E+01$ & $\mathbf{P}$ & & & \\
\hline $\mathrm{Pb}$ & & & & $\mathrm{Pb}$ & $4.60 \mathrm{E}+01$ & $1.94 \mathrm{E}+01$ & $4.22 \mathrm{E}+01$ \\
\hline Pd & & & & Pd & $2.85 \mathrm{E}+00$ & 7.73E-01 & $2.71 E+01$ \\
\hline Pt & & & & $\mathbf{P t}$ & 2.14E-01 & 1.70E-02 & $7.94 \mathrm{E}+00$ \\
\hline $\operatorname{Re}$ & & & & $\operatorname{Re}$ & $2.46 \mathrm{E}-02$ & $1.95 \mathrm{E}-04$ & 7.93E-01 \\
\hline $\mathbf{R u}$ & & & & $\mathbf{R u}$ & $5.08 \mathrm{E}+01$ & $2.64 \mathrm{E}+01$ & $5.20 \mathrm{E}+01$ \\
\hline $\mathrm{Rh}$ & & & & Rh & $1.15 \mathrm{E}+01$ & $5.68 \mathrm{E}+00$ & $4.94 \mathrm{E}+01$ \\
\hline $\mathrm{Se}$ & & & & $\mathrm{Se}$ & $2.55 \mathrm{E}+01$ & $1.66 \mathrm{E}+00$ & $6.51 \mathrm{E}+00$ \\
\hline $\mathbf{S i}$ & $7.46 \mathrm{E}+03$ & $2.25 \mathrm{E}+03$ & $3.02 \mathrm{E}+01$ & Si & $7.46 \mathrm{E}+03$ & $2.25 \mathrm{E}+03$ & $3.02 \mathrm{E}+01$ \\
\hline Sn & $1.66 \mathrm{E}+02$ & $7.05 \mathrm{E}+00$ & $4.24 \mathrm{E}+00$ & Sn & $1.11 \mathrm{E}+01$ & $1.93 \mathrm{E}+00$ & $1.74 \mathrm{E}+01$ \\
\hline $\mathrm{Sr}$ & $6.11 \mathrm{E}+01$ & $2.24 \mathrm{E}+01$ & $3.67 \mathrm{E}+01$ & $\mathrm{Sr}$ & & & \\
\hline $\mathrm{Ti}$ & $1.65 \mathrm{E}+02$ & $2.69 \mathrm{E}+01$ & $1.63 \mathrm{E}+01$ & $\mathrm{Ti}$ & $1.88 \mathrm{E}+02$ & $8.81 E+01$ & $4.69 \mathrm{E}+01$ \\
\hline v & $1.03 \mathrm{E}+02$ & 1.35E+01 & $1.31 \mathrm{E}+01$ & V & $1.27 \mathrm{E}+02$ & $6.33 \mathrm{E}+00$ & 4.98E+00 \\
\hline $\mathrm{Zn}$ & $6.28 \mathrm{E}+03$ & $1.27 \mathrm{E}+02$ & $2.02 \mathrm{E}+00$ & $\mathrm{Zn}$ & $3.74 \mathrm{E}+03$ & $3.24 \mathrm{E}+02$ & $8.66 \mathrm{E}+00$ \\
\hline $\mathrm{Zr}$ & & & & $\mathrm{Zr}$ & & & \\
\hline U & & & & $\mathbf{U}$ & $3.69 \mathrm{E}+03$ & $1.87 \mathrm{E}+03$ & $5.07 \mathrm{E}+01$ \\
\hline W & & & & W & $1.40 \mathrm{E}+00$ & 7.67E-01 & $5.48 \mathrm{E}+01$ \\
\hline
\end{tabular}




\begin{tabular}{|c|c|c|c|c|c|c|c|}
\hline & & Composi & $\begin{array}{r}\text { Apper } \\
n \text { of Tan }\end{array}$ & $\begin{array}{l}\times 9.8 \\
1 H \text { Sludg }\end{array}$ & Sample & & \\
\hline Analyte & $\begin{array}{c}\text { Average } \\
\mathrm{nCi} / \mathrm{g}\end{array}$ & $\begin{array}{l}\text { Stdev } \\
\mathrm{nCi} / \mathrm{g}\end{array}$ & \%RSD & Analyte & $\begin{array}{c}\text { Average } \\
\mathrm{nCi} / \mathrm{g}\end{array}$ & $\begin{array}{l}\text { Stdev } \\
\mathrm{nCi} / \mathrm{g}\end{array}$ & \%RSD \\
\hline Cs-137 & $1.04 \mathrm{E}+06$ & $7.63 \mathrm{E}+04$ & $7.35 \mathrm{E}+00$ & Alpha total & $9.78 \mathrm{E}+05$ & $1.30 \mathrm{E}+05$ & $1.33 \mathrm{E}+01$ \\
\hline Am-241 & $3.10 \mathrm{E}+04$ & $2.76 \mathrm{E}+04$ & $8.90 \mathrm{E}+01$ & $\mathrm{Pu}-239 / 240$ & $0.00 \mathrm{E}+00$ & $0.00 \mathrm{E}+00$ & \\
\hline Eu-154 & $1.65 \mathrm{E}+05$ & $9.24 \mathrm{E}+03$ & $5.61 E+00$ & Pu-238/241 & $9.31 E+05$ & $7.29 E+04$ & $7.83 E+00$ \\
\hline Eu-155 & $2.91 \mathrm{E}+04$ & $5.60 \mathrm{E}+03$ & $1.92 \mathrm{E}+01$ & $\mathrm{Cm}-244$ & $4.66 \mathrm{E}+04$ & $5.73 \mathrm{E}+04$ & $1.23 E+02$ \\
\hline $\mathrm{Co}-60$ & $1.92 \mathrm{E}+03$ & $3.33 E+03$ & $1.73 E+02$ & $\mathrm{Sr}-90$ & $0.00 \mathrm{E}+00$ & $0.00 \mathrm{E}+00$ & \\
\hline ICP-ES & $\mu \mathrm{g} / \mathrm{g}$ & $\mu \mathrm{g} / \mathrm{g}$ & & ICP-MS & $\mu g / g$ & $\mu \mathrm{g} / \mathrm{g}$ & \\
\hline $\mathbf{A g}$ & & & & $\mathrm{Ag}$ & $2.10 \mathrm{E}+03$ & $7.44 \mathrm{E}+02$ & $3.54 \mathrm{E}+01$ \\
\hline Al & $2.46 \mathrm{E}+05$ & $8.53 \mathrm{E}+03$ & $3.47 \mathrm{E}+00$ & $\mathrm{Al}$ & & & \\
\hline $\mathrm{Au}$ & & & & $\mathrm{Au}$ & $2.44 \mathrm{E}+00$ & 3.97E-01 & $1.63 E+01$ \\
\hline B & & & & B & & & \\
\hline $\mathrm{Ba}$ & $1.56 \mathrm{E}+03$ & $8.45 \mathrm{E}+01$ & $5.42 \mathrm{E}+00$ & $\mathbf{B a}$ & & & \\
\hline $\mathrm{Ca}$ & $2.24 E+03$ & $2.07 E+02$ & $9.26 \mathrm{E}+00$ & $\mathrm{Ca}$ & $1.50 \mathrm{E}+04$ & $3.96 \mathrm{E}+02$ & $2.64 \mathrm{E}+00$ \\
\hline $\mathrm{Cd}$ & 4.47E+02 & $1.38 \mathrm{E}+02$ & $3.09 \mathrm{E}+01$ & $\mathrm{Cd}$ & $8.36 \mathrm{E}+02$ & $5.48 \mathrm{E}+02$ & $6.56 \mathrm{E}+01$ \\
\hline $\mathrm{Ce}$ & $2.87 \mathrm{E}+04$ & $4.33 E+03$ & $1.51 E+01$ & $\mathrm{Ce}$ & $7.15 E+03$ & $1.11 \mathrm{E}+02$ & $1.55 \mathrm{E}+00$ \\
\hline Co & & & & Co & $1.24 \mathrm{E}+02$ & $2.15 \mathrm{E}+01$ & $1.73 \mathrm{E}+01$ \\
\hline $\mathrm{Cr}$ & $1.19 \mathrm{E}+03$ & $1.24 \mathrm{E}+02$ & $1.05 \mathrm{E}+01$ & $\mathrm{Cr}$ & $3.75 \mathrm{E}+03$ & $1.43 E+02$ & $3.81 \mathrm{E}+00$ \\
\hline $\mathrm{Cu}$ & $1.69 \mathrm{E}+03$ & $1.44 \mathrm{E}+02$ & $8.51 E+00$ & $\mathrm{Cu}$ & $3.56 \mathrm{E}+03$ & $1.35 E+02$ & $3.79 \mathrm{E}+00$ \\
\hline $\mathrm{Fe}$ & $3.54 \mathrm{E}+04$ & $2.11 \mathrm{E}+03$ & $5.98 \mathrm{E}+00$ & $\mathrm{Fe}$ & $1.84 E+05$ & $9.73 E+03$ & $5.29 \mathrm{E}+00$ \\
\hline $\mathrm{Hg}$ & & & & $\mathrm{Hg}$ & $4.04 E+04$ & $7.16 \mathrm{E}+03$ & $1.77 \mathrm{E}+01$ \\
\hline Ir & & & & Ir & & & \\
\hline $\mathrm{La}$ & $3.46 \mathrm{E}+03$ & $5.19 \mathrm{E}+02$ & $1.50 \mathrm{E}+01$ & $\mathrm{La}$ & $3.68 E+03$ & $1.44 \mathrm{E}+02$ & $3.91 \mathrm{E}+00$ \\
\hline $\mathbf{L i}$ & $1.40 \mathrm{E}+03$ & $2.25 \mathrm{E}+02$ & $1.61 \mathrm{E}+01$ & $\mathbf{L i}$ & & & \\
\hline $\mathrm{Mg}$ & $1.26 \mathrm{E}+03$ & $8.48 \mathrm{E}+01$ & $6.71 E+00$ & $\mathrm{Mg}$ & & & \\
\hline $\mathrm{Mn}$ & $1.67 E+04$ & $6.64 E+02$ & $3.96 \mathrm{E}+00$ & $\mathrm{Mn}$ & $1.00 E+05$ & $3.10 E+03$ & $3.10 \mathrm{E}+00$ \\
\hline Mo & $9.95 \mathrm{E}+02$ & $6.91 E+01$ & $6.95 \mathrm{E}+00$ & Mo & $2.06 \mathrm{E}+02$ & $2.94 \mathrm{E}+01$ & $1.43 \mathrm{E}+01$ \\
\hline $\mathrm{Na}$ & 9.37E+04 & $5.33 E+03$ & $5.69 \mathrm{E}+00$ & $\mathrm{Na}$ & & & \\
\hline $\mathrm{Ni}$ & $9.30 \mathrm{E}+03$ & $2.75 E+02$ & $2.96 \mathrm{E}+00$ & $\mathrm{Ni}$ & $3.69 \mathrm{E}+04$ & $1.49 E+03$ & $4.03 E+00$ \\
\hline Os & & & & Os & & & \\
\hline $\mathbf{P}$ & $3.18 \mathrm{E}+03$ & $5.31 \mathrm{E}+02$ & $1.67 \mathrm{E}+01$ & $\mathbf{P}$ & & & \\
\hline $\mathbf{P b}$ & $5.61 E+03$ & $7.64 \mathrm{E}+02$ & $1.36 \mathrm{E}+01$ & $\mathrm{~Pb}$ & $5.87 \mathrm{E}+02$ & $7.11 E+01$ & $1.21 E+01$ \\
\hline $\mathbf{P d}$ & $\cdots$ & & & Pd & $1.28 \mathrm{E}+02$ & $1.77 \mathrm{E}+01$ & $1.38 E+01$ \\
\hline $\mathbf{P t}$ & & & & $\mathrm{Pt}$ & $1.53 \mathrm{E}+01$ & $2.31 E+01$ & $1.51 \mathrm{E}+02$ \\
\hline $\operatorname{Re}$ & & & & $\operatorname{Re}$ & & & \\
\hline $\mathbf{R h}$ & & & & $\mathbf{R h}$ & $8.70 \mathrm{E}+02$ & $1.78 \mathrm{E}+01$ & $2.05 E+00$ \\
\hline $\mathbf{R u}$ & & & & $\mathbf{R u}$ & $4.19 \mathrm{E}+03$ & $1.82 \mathrm{E}+02$ & $4.34 \mathrm{E}+00$ \\
\hline $\mathrm{Se}$ & & & & $\mathrm{Se}$ & $7.90 \mathrm{E}+02$ & $1.06 \mathrm{E}+02$ & $1.34 \mathrm{E}+01$ \\
\hline $\mathrm{Si}$ & $8.79 \mathrm{E}+03$ & $1.12 \mathrm{E}+03$ & $1.27 \mathrm{E}+01$ & $\mathrm{Si}$ & & & \\
\hline Sn & $1.65 \mathrm{E}+03$ & $2.22 \mathrm{E}+02$ & $1.35 \mathrm{E}+01$ & Sn & $7.36 \mathrm{E}+01$ & $6.37 \mathrm{E}+01$ & $8.65 E+01$ \\
\hline $\mathrm{Sr}$ & $3.08 \mathrm{E}+02$ & $4.84 \mathrm{E}+01$ & $1.57 E+01$ & $\mathrm{Sr}$ & & & \\
\hline Tc & & & & $\mathrm{Tc}$ & $1.12 E+02$ & $1.50 \mathrm{E}+00$ & $1.34 \mathrm{E}+00$ \\
\hline $\mathrm{Ti}$ & $1.16 \mathrm{E}+03$ & $2.62 E+02$ & $2.26 \mathrm{E}+01$ & $\mathrm{Ti}$ & $7.29 \mathrm{E}+02$ & $6.51 \mathrm{E}+01$ & $8.93 \mathrm{E}+00$ \\
\hline V & $1.32 E+03$ & $2.69 \mathrm{E}+02$ & $2.03 E+01$ & v & $3.13 E+03$ & $1.20 \mathrm{E}+02$ & $3.83 E+00$ \\
\hline $\mathrm{Zn}$ & $2.45 \mathrm{E}+02$ & $4.74 \mathrm{E}+01$ & $1.93 \mathrm{E}+01$ & $\mathrm{Zn}$ & $2.32 E+03$ & $1.93 E+02$ & $8.32 E+00$ \\
\hline $\mathrm{Zr}$ & & & & $\mathrm{Zr}$ & & & \\
\hline W & & & & W & $1.31 E+00$ & $2.27 \mathrm{E}+00$ & $1.73 \mathrm{E}+02$ \\
\hline
\end{tabular}


Appendix 9.9

\section{Composition of Batch 2 Feed Slurry and \\ Calculated Composition of Test 2.7 Slurry}

\begin{tabular}{|c|c|c|c|c|c|c|c|}
\hline Element & $\begin{array}{l}\text { ECC } \\
\mathrm{mg} / \mathrm{L}\end{array}$ & $\begin{array}{c}\text { Batch 2 } \\
\text { Minimum } \\
\text { mg/L }\end{array}$ & $\begin{array}{c}\text { Batch } 2 \\
\text { Average } \\
\text { mg/L }\end{array}$ & $\begin{array}{c}\text { Batch } 2 \\
\text { Maximum } \\
\text { mg/L }\end{array}$ & $\begin{array}{c}\text { Test } 2.7 \\
\text { Minimum } \\
\text { mg/L }\end{array}$ & $\begin{array}{c}\text { Test } 2.7 \\
\text { Average } \\
\text { mg/L }\end{array}$ & $\begin{array}{c}\text { Test } 2.7 \\
\text { Maximum } \\
\text { mg/L }\end{array}$ \\
\hline$\overline{\mathbf{M g}}$ & $2.00 \mathrm{E}+00$ & $2.40 \mathrm{E}-01$ & $2.40 \mathrm{E}-01$ & $2.40 \mathrm{E}-01$ & $1.50 \mathrm{E}-01$ & $1.50 \mathrm{E}-01$ & $1.50 \mathrm{E}-01$ \\
\hline $\mathrm{Al}$ & $9.60 \mathrm{E}+01$ & $4.78 \mathrm{E}+03$ & $4.81 E+03$ & $4.84 E+03$ & $2.98 \mathrm{E}+03$ & $3.00 \mathrm{E}+03$ & $3.01 E+03$ \\
\hline $\mathbf{S i}$ & $1.60 \mathrm{E}+01$ & $1.24 \mathrm{E}+01$ & $1.96 \mathrm{E}+01$ & $2.68 \mathrm{E}+01$ & $7.75 \mathrm{E}+00$ & $1.22 \mathrm{E}+01$ & $1.67 \mathrm{E}+01$ \\
\hline $\mathrm{Ca}$ & $1.22 \mathrm{E}+01$ & $1.90 \mathrm{E}+02$ & $2.06 \mathrm{E}+02$ & $2.22 \mathrm{E}+02$ & $1.19 \mathrm{E}+02$ & $1.28 \mathrm{E}+02$ & $1.38 \mathrm{E}+02$ \\
\hline $\mathbf{T i}$ & $9.57 \mathrm{E}+02$ & $1.13 E+02$ & $1.72 \mathrm{E}+02$ & $2.31 \mathrm{E}+02$ & $7.01 \mathrm{E}+01$ & $1.07 \mathrm{E}+02$ & $1.44 \mathrm{E}+02$ \\
\hline v & & $2.74 \mathrm{E}+01$ & $5.08 \mathrm{E}+01$ & $7.42 \mathrm{E}+01$ & $1.71 \mathrm{E}+01$ & $3.16 \mathrm{E}+01$ & $4.62 \mathrm{E}+01$ \\
\hline $\mathrm{Cr}$ & $6.40 E+01$ & $2.82 \mathrm{E}+01$ & $2.91 \mathrm{E}+01$ & $3.00 \mathrm{E}+01$ & $1.76 \mathrm{E}+01$ & $1.81 \mathrm{E}+01$ & $1.87 \mathrm{E}+01$ \\
\hline $\mathbf{M n}$ & $1.18 E+02$ & $7.98 \mathrm{E}+00$ & $8.71 E+00$ & $9.44 E+00$ & $4.97 \mathrm{E}+00$ & $5.43 E+00$ & $5.88 \mathrm{E}+00$ \\
\hline $\mathbf{F e}$ & $5.79 \mathrm{E}+02$ & $1.27 \mathrm{E}+02$ & $1.66 \mathrm{E}+02$ & $2.05 E+02$ & $7.91 \mathrm{E}+01$ & $1.03 E+02$ & $1.28 \mathrm{E}+02$ \\
\hline $\mathbf{N i}$ & $5.00 \mathrm{E}+01$ & $4.50 \mathrm{E}+00$ & 1.17E+01 & $1.89 \mathrm{E}+01$ & $2.80 \mathrm{E}+00$ & $7.29 \mathrm{E}+00$ & $1.18 \mathrm{E}+01$ \\
\hline Co & $4.00 \mathrm{E}-02$ & $5.26 \mathrm{E}-02$ & $1.39 \mathrm{E}-01$ & $2.25 \mathrm{E}-01$ & $3.28 \mathrm{E}-02$ & $8.66 \mathrm{E}-02$ & $1.40 \mathrm{E}-01$ \\
\hline $\mathbf{C u}$ & $3.70 \mathrm{E}+00$ & $2.89 \mathrm{E}+00$ & $3.44 E+00$ & $3.99 E+00$ & $1.80 \mathrm{E}+00$ & $2.14 \mathrm{E}+00$ & $2.48 \mathrm{E}+00$ \\
\hline $\mathbf{Z n}$ & $1.28 \mathrm{E}+01$ & $8.40 \mathrm{E}+00$ & $1.01 E+01$ & $1.18 \mathrm{E}+01$ & $5.23 \mathrm{E}+00$ & $6.29 \mathrm{E}+00$ & $7.35 \mathrm{E}+00$ \\
\hline As & $4.00 \mathrm{E}-02$ & $2.70 \mathrm{E}+01$ & $3.42 \mathrm{E}+01$ & $4.14 E+01$ & $1.68 \mathrm{E}+01$ & $2.13 E+01$ & $2.58 E+01$ \\
\hline Se & $1.00 \mathrm{E}+00$ & $6.64 \mathrm{E}+00$ & $9.08 \mathrm{E}+00$ & $1.15 \mathrm{E}+01$ & $4.14 \mathrm{E}+00$ & $5.66 \mathrm{E}+00$ & $7.18 \mathrm{E}+00$ \\
\hline $\mathbf{S r}$ & $1.00 \mathrm{E}-01$ & $7.08 \mathrm{E}+00$ & $1.32 E+01$ & $1.93 E+01$ & $4.41 \mathrm{E}+00$ & $8.22 \mathrm{E}+00$ & $1.20 \mathrm{E}+01$ \\
\hline $\mathbf{Z r}$ & $5.00 \mathrm{E}+01$ & $0.00 \mathrm{E}+00$ & $2.29 \mathrm{E}+00$ & $5.09 \mathrm{E}+00$ & $0.00 \mathrm{E}+00$ & $1.43 E+00$ & $3.17 E+00$ \\
\hline Mo & $1.20 \mathrm{E}+01$ & $1.93 E+01$ & $2.04 \mathrm{E}+01$ & $2.15 \mathrm{E}+01$ & $1.20 \mathrm{E}+01$ & 1.27E+01 & $1.34 \mathrm{E}+01$ \\
\hline Ru & $5.40 \mathrm{E}+00$ & $0.00 \mathrm{E}+00$ & $8.82 \mathrm{E}-02$ & $3.94 \mathrm{E}-01$ & $0.00 \mathrm{E}+00$ & $5.49 \mathrm{E}-02$ & $2.46 \mathrm{E}-01$ \\
\hline $\mathbf{R h}$ & $1.40 \mathrm{E}+00$ & $1.96 \mathrm{E}-01$ & $4.46 \mathrm{E}-01$ & $6.96 \mathrm{E}-01$ & $1.22 \mathrm{E}-01$ & 2.78E-01 & $4.34 \mathrm{E}-01$ \\
\hline Pd & $2.60 \mathrm{E}+00$ & $0.00 \mathrm{E}+00$ & $2.57 \mathrm{E}-01$ & $5.15 \mathrm{E}-01$ & $0.00 \mathrm{E}+00$ & $1.60 \mathrm{E}-01$ & $3.21 \mathrm{E}-01$ \\
\hline $\mathbf{A g}$ & $6.80 \mathrm{E}+00$ & $0.00 \mathrm{E}+00$ & $9.92 \mathrm{E}+00$ & $2.35 \mathrm{E}+01$ & $0.00 \mathrm{E}+00$ & $6.18 E+00$ & $1.47 E+01$ \\
\hline Cd & $4.00 \mathrm{E}-01$ & $1.72 \mathrm{E}+00$ & $3.90 \mathrm{E}+00$ & $6.08 \mathrm{E}+00$ & $1.07 \mathrm{E}+00$ & $2.43 E+00$ & $3.79 E+00$ \\
\hline Sn & $2.10 \mathrm{E}+00$ & $1.97 \mathrm{E}+00$ & $2.71 E+00$ & $3.45 \mathrm{E}+00$ & $1.23 E+00$ & $1.69 \mathrm{E}+00$ & $2.15 E+00$ \\
\hline $\mathbf{L a}$ & $5.00 \mathrm{E}-02$ & $0.00 \mathrm{E}+00$ & $2.75 E+00$ & $7.45 \mathrm{E}+00$ & $0.00 \mathrm{E}+00$ & $1.71 \mathrm{E}+00$ & $4.64 \mathrm{E}+00$ \\
\hline $\mathrm{Ce}$ & $3.00 \mathrm{E}-01$ & $0.00 \mathrm{E}+00$ & $2.57 \mathrm{E}-01$ & $6.05 \mathrm{E}-01$ & $0.00 \mathrm{E}+00$ & $1.60 \mathrm{E}-01$ & $3.77 \mathrm{E}-01$ \\
\hline $\mathbf{w}$ & & $5.24 \mathrm{E}-01$ & $1.13 E+00$ & $1.74 E+00$ & $3.26 \mathrm{E}-01$ & $7.04 \mathrm{E}-01$ & $1.08 E+00$ \\
\hline $\operatorname{Re}$ & & $0.00 \mathrm{E}+00$ & $0.00 \mathrm{E}+00$ & $0.00 \mathrm{E}+00$ & $0.00 \mathrm{E}+00$ & $0.00 \mathrm{E}+00$ & $0.00 \mathrm{E}+00$ \\
\hline Os & & $0.00 \mathrm{E}+00$ & $0.00 E+00$ & $0.00 \mathrm{E}+00$ & $0.00 \mathrm{E}+00$ & $0.00 \mathrm{E}+00$ & $0.00 \mathrm{E}+00$ \\
\hline $\mathbf{I r}$ & & $0.00 \mathrm{E}+00$ & $0.00 \mathrm{E}+00$ & $0.00 \mathrm{E}+00$ & $0.00 \mathrm{E}+00$ & $0.00 \mathrm{E}+00$ & $0.00 \mathrm{E}+00$ \\
\hline $\mathbf{P t}$ & & $0.00 \mathrm{E}+00$ & $0.00 \mathrm{E}+00$ & $0.00 \mathrm{E}+00$ & $0.00 \mathrm{E}+00$ & $0.00 \mathrm{E}+00$ & $0.00 \mathrm{E}+00$ \\
\hline Au & & $0.00 \mathrm{E}+00$ & $0.00 \mathrm{E}+00$ & $0.00 \mathrm{E}+00$ & $0.00 \mathrm{E}+00$ & $0.00 \mathrm{E}+00$ & $0.00 \mathrm{E}+00$ \\
\hline $\mathrm{Hg}$ & $8.48 \mathrm{E}+01$ & $0.00 \mathrm{E}+00$ & 5.31E-01 & $1.31 \mathrm{E}+00$ & $0.00 \mathrm{E}+00$ & $3.31 \mathrm{E}-01$ & $8.17 \mathrm{E}-01$ \\
\hline $\mathbf{P b}$ & $6.00 \mathrm{E}+00$ & $4.36 \mathrm{E}+00$ & $5.73 E+00$ & $7.10 \mathrm{E}+00$ & $2.72 \mathrm{E}+00$ & $3.57 \mathrm{E}+00$ & $4.42 \mathrm{E}+00$ \\
\hline $\mathbf{U}$ & & $6.06 \mathrm{E}+00$ & $2.03 E+01$ & $3.45 \mathrm{E}+01$ & $3.78 \mathrm{E}+00$ & $1.26 \mathrm{E}+01$ & $2.15 E+01$ \\
\hline
\end{tabular}


Appendix 9.10

Calculated Composition of Tests $3 A$ and 3B Slurries

\begin{tabular}{|c|c|c|c|c|c|c|c|}
\hline Element & $\begin{array}{l}\text { ECC } \\
\mathrm{mg} / \mathrm{L}\end{array}$ & $\begin{array}{c}\text { Test 3A } \\
\text { Minimum } \\
\text { mg/L }\end{array}$ & $\begin{array}{c}\text { Test 3A } \\
\text { Average } \\
\text { mg/L }\end{array}$ & $\begin{array}{c}\text { Test 3A } \\
\text { Maximum } \\
\text { mg/L }\end{array}$ & $\begin{array}{c}\text { Test 3B } \\
\text { Minimum } \\
\text { mg/L }\end{array}$ & $\begin{array}{c}\text { Test 3B } \\
\text { Average } \\
\text { mg/L }\end{array}$ & $\begin{array}{c}\text { Test 3B } \\
\text { Maximum } \\
\text { mg/L }\end{array}$ \\
\hline $\mathbf{M g}$ & $2.00 \mathrm{E}+00$ & $1.83 \mathrm{E}+00$ & $2.65 E+00$ & $3.47 E+00$ & $1.98 \mathrm{E}+00$ & $3.06 \mathrm{E}+00$ & $4.14 \mathrm{E}+00$ \\
\hline Al & $9.60 \mathrm{E}+01$ & $7.64 E+03$ & $7.67 \mathrm{E}+03$ & $7.70 \mathrm{E}+03$ & $7.74 \mathrm{E}+03$ & $7.78 \mathrm{E}+03$ & $7.81 \mathrm{E}+03$ \\
\hline $\mathbf{S i}$ & $1.60 \mathrm{E}+01$ & $1.19 E+01$ & $2.39 \mathrm{E}+01$ & $3.59 \mathrm{E}+01$ & $1.31 \mathrm{E}+01$ & $2.77 \mathrm{E}+01$ & $4.23 \mathrm{E}+01$ \\
\hline $\mathrm{Ca}$ & $1.22 \mathrm{E}+01$ & $4.24 \mathrm{E}+01$ & $5.44 E+01$ & $6.72 E+01$ & $2.20 \mathrm{E}+01$ & $3.52 \mathrm{E}+01$ & $4.95 \mathrm{E}+01$ \\
\hline $\mathbf{T i}$ & $9.57 \mathrm{E}+02$ & $6.72 \mathrm{E}+01$ & $7.68 \mathrm{E}+01$ & $8.64 \mathrm{E}+01$ & $5.37 \mathrm{E}+01$ & $6.64 \mathrm{E}+01$ & $5.85 \mathrm{E}+01$ \\
\hline $\mathbf{V}$ & & $5.05 \mathrm{E}+00$ & $8.98 E+00$ & $1.29 \mathrm{E}+01$ & $1.88 \mathrm{E}+00$ & $2.98 \mathrm{E}+00$ & $4.12 \mathrm{E}+00$ \\
\hline $\mathrm{Cr}$ & $6.40 \mathrm{E}+01$ & $9.81 E+01$ & $1.08 \mathrm{E}+02$ & 1.17E+02 & $1.09 \mathrm{E}+02$ & $1.22 E+02$ & $1.34 \mathrm{E}+02$ \\
\hline Mn & $1.18 \mathrm{E}+02$ & $2.57 \mathrm{E}+01$ & $2.88 \mathrm{E}+01$ & $3.19 \mathrm{E}+01$ & $3.12 \mathrm{E}+01$ & $3.50 \mathrm{E}+01$ & $3.88 \mathrm{E}+01$ \\
\hline $\mathbf{F e}$ & $5.79 \mathrm{E}+02$ & $6.30 \mathrm{E}+01$ & $8.53 E+01$ & $1.08 \mathrm{E}+02$ & $5.76 \mathrm{E}+01$ & $8.02 E+01$ & $1.03 E+02$ \\
\hline $\mathbf{N i}$ & $5.00 \mathrm{E}+01$ & $1.24 \mathrm{E}+01$ & $1.76 \mathrm{E}+01$ & $2.28 \mathrm{E}+01$ & $1.47 \mathrm{E}+01$ & $2.03 E+01$ & $2.59 E+01$ \\
\hline Co & $4.00 \mathrm{E}-02$ & $1.11 \mathrm{E}-01$ & $1.60 \mathrm{E}-01$ & $2.13 \mathrm{E}-01$ & $1.13 \mathrm{E}-01$ & 1.58E-01 & $2.10 \mathrm{E}-01$ \\
\hline $\mathrm{Cu}$ & $3.70 \mathrm{E}+\infty 0$ & $7.61 \mathrm{E}+00$ & $1.32 E+01$ & $1.88 \mathrm{E}+01$ & $9.08 \mathrm{E}+00$ & $1.65 \mathrm{E}+01$ & $2.38 \mathrm{E}+01$ \\
\hline $\mathbf{Z n}$ & $1.28 \mathrm{E}+01$ & $8.15 E+00$ & $9.00 \mathrm{E}+00$ & $9.84 \mathrm{E}+00$ & $8.93 \mathrm{E}+00$ & $9.75 E+00$ & $1.06 \mathrm{E}+01$ \\
\hline As & $4.00 \mathrm{E}-02$ & $5.00 \mathrm{E}+00$ & $6.19 E+00$ & $7.38 E+00$ & $1.71 E+\infty 0$ & $2.03 E+00$ & $2.36 \mathrm{E}+00$ \\
\hline Se & $1.00 \mathrm{E}+00$ & $2.84 \mathrm{E}+00$ & $5.01 E+00$ & $8.48 \mathrm{E}+00$ & $2.58 \mathrm{E}+00$ & $4.72 \mathrm{E}+00$ & $8.11 E+00$ \\
\hline $\mathbf{S r}$ & $1.00 \mathrm{E}-01$ & $1.46 \mathrm{E}+00$ & $2.63 E+00$ & $3.80 \mathrm{E}+00$ & $6.97 \mathrm{E}-01$ & 1.17E+00 & $1.65 \mathrm{E}+00$ \\
\hline $\mathbf{Z r}$ & $5.00 E+01$ & $3.18 \mathrm{E}+00$ & $6.35 E+00$ & $9.66 \mathrm{E}+00$ & $4.02 \mathrm{E}+00$ & $7.63 E+00$ & $1.13 E+01$ \\
\hline Mo & $1.20 \mathrm{E}+01$ & $3.23 E+01$ & $3.69 \mathrm{E}+01$ & 4.15E+01 & $3.31 \mathrm{E}+01$ & $3.81 \mathrm{E}+01$ & $4.31 \mathrm{E}+01$ \\
\hline Ru & $5.40 \mathrm{E}+00$ & $3.18 \mathrm{E}+00$ & $3.71 E+00$ & $4.35 E+00$ & $3.88 \mathrm{E}+00$ & $4.53 E+00$ & $5.25 E+00$ \\
\hline $\mathbf{R h}$ & $1.40 \mathrm{E}+00$ & $1.19 \mathrm{E}+00$ & $1.34 E+00$ & $1.48 \mathrm{E}+00$ & $1.43 E+00$ & $1.56 \mathrm{E}+00$ & $1.70 \mathrm{E}+00$ \\
\hline Pd & $2.60 \mathrm{E}+00$ & $6.04 \mathrm{E}-02$ & $1.54 \mathrm{E}-01$ & $2.62 \mathrm{E}-01$ & $7.17 \mathrm{E}-02$ & $1.36 \mathrm{E}-01$ & $2.14 \mathrm{E}-01$ \\
\hline $\mathbf{A g}$ & $6.80 \mathrm{E}+00$ & $3.76 \mathrm{E}-01$ & $2.81 E+00$ & $5.80 \mathrm{E}+00$ & $4.43 \mathrm{E}-01$ & $1.78 \mathrm{E}+00$ & $3.21 \mathrm{E}+00$ \\
\hline Cd & $4.00 \mathrm{E}-01$ & $6.76 \mathrm{E}-01$ & $1.49 \mathrm{E}+00$ & $2.33 E+00$ & $5.62 \mathrm{E}-01$ & $1.20 \mathrm{E}+00$ & $1.87 \mathrm{E}+00$ \\
\hline Sn & $2.10 \mathrm{E}+00$ & $2.78 \mathrm{E}+00$ & $3.59 \mathrm{E}+00$ & $4.39 \mathrm{E}+00$ & $3.22 \mathrm{E}+00$ & $4.01 E+00$ & $4.80 \mathrm{E}+00$ \\
\hline $\mathbf{L a}$ & $5.00 \mathrm{E}-02$ & $1.82 \mathrm{E}+00$ & $2.97 \mathrm{E}+00$ & $4.41 \mathrm{E}+00$ & $2.20 \mathrm{E}+00$ & 3.13E+00 & $4.11 \mathrm{E}+00$ \\
\hline $\mathrm{Ce}$ & $3.00 \mathrm{E}-01$ & $1.25 \mathrm{E}+01$ & $1.78 \mathrm{E}+01$ & $2.31 E+01$ & $1.47 \mathrm{E}+01$ & $2.09 \mathrm{E}+01$ & $2.71 E+01$ \\
\hline $\mathbf{W}$ & & $4.61 \mathrm{E}-01$ & $7.60 \mathrm{E}-01$ & $1.06 \mathrm{E}+00$ & $4.78 \mathrm{E}-01$ & $7.34 \mathrm{E}-01$ & $9.93 \mathrm{E}-01$ \\
\hline $\mathbf{R e}$ & & $1.10 \mathrm{E}-03$ & $1.58 \mathrm{E}-03$ & $2.08 \mathrm{E}-03$ & $1.47 \mathrm{E}-03$ & $2.11 E-03$ & $2.78 \mathrm{E}-03$ \\
\hline Os & & $0.00 \mathrm{E}+00$ & $2.27 \mathrm{E}-03$ & $9.93 \mathrm{E}-03$ & $0.00 \mathrm{E}+00$ & $2.33 \mathrm{E}-03$ & $1.01 \mathrm{E}-02$ \\
\hline Ir & & $0.00 E+00$ & $6.76 \mathrm{E}-04$ & 2.62E-03 & $0.00 \mathrm{E}+00$ & $7.11 E-04$ & $2.64 \mathrm{E}-03$ \\
\hline $\mathbf{P t}$ & & $1.23 \mathrm{E}-03$ & 1.25E-02 & 4.48E-02 & $1.64 \mathrm{E}-03$ & $1.50 \mathrm{E}-02$ & $5.26 \mathrm{E}-02$ \\
\hline Au & & 1.10E-03 & 2.10E-03 & $3.76 \mathrm{E}-03$ & $1.30 \mathrm{E}-03$ & $2.47 \mathrm{E}-03$ & $4.27 \mathrm{E}-03$ \\
\hline $\mathbf{H g}$ & $8.48 \mathrm{E}+01$ & $4.07 \mathrm{E}+01$ & $5.31 E+01$ & $6.55 \mathrm{E}+01$ & $4.38 \mathrm{E}+01$ & $5.77 \mathrm{E}+01$ & $7.17 \mathrm{E}+01$ \\
\hline $\mathbf{P b}$ & $6.00 \mathrm{E}+00$ & $4.51 E+00$ & $6.41 \mathrm{E}+00$ & $8.31 \mathrm{E}+00$ & $4.57 \mathrm{E}+00$ & $6.49 \mathrm{E}+00$ & $8.42 \mathrm{E}+00$ \\
\hline $\mathbf{U}$ & & $4.18 \mathrm{E}+00$ & $8.14 \mathrm{E}+00$ & $1.23 \mathrm{E}+01$ & $4.32 \mathrm{E}+00$ & $6.73 E+00$ & $9.38 \mathrm{E}+00$ \\
\hline
\end{tabular}


Appendix 9.11

\begin{tabular}{|c|c|c|c|c|c|c|c|}
\hline \multirow[b]{2}{*}{ Element } & \multicolumn{6}{|c|}{ Calculated Composition of Tests $3 C$ and $3 D$ Slurries } & \multirow[b]{2}{*}{$\begin{array}{c}\text { Test 3D } \\
\text { Maximum } \\
\text { mg/L }\end{array}$} \\
\hline & $\begin{array}{l}\text { ECC } \\
\mathrm{mg} / \mathrm{L}\end{array}$ & $\begin{array}{c}\text { Test 3C } \\
\text { Minimum } \\
\text { mg/L }\end{array}$ & $\begin{array}{c}\text { Test 3C } \\
\text { Average } \\
\text { mg/L }\end{array}$ & $\begin{array}{c}\text { Test 3C } \\
\text { Maximum } \\
\text { mg/L }\end{array}$ & $\begin{array}{c}\text { Test 3D } \\
\text { Minimum } \\
\text { mg/L }\end{array}$ & $\begin{array}{c}\text { Test 3D } \\
\text { Average } \\
\text { mg/L }\end{array}$ & \\
\hline$\overline{\mathbf{M g}}$ & $2.00 \mathrm{E}+00$ & $1.84 \mathrm{E}+00$ & $2.66 \mathrm{E}+00$ & $3.49 \mathrm{E}+00$ & $1.97 \mathrm{E}+00$ & $3.04 \mathrm{E}+00$ & $4.10 \mathrm{E}+00$ \\
\hline Al & $9.60 \mathrm{E}+01$ & $7.64 \mathrm{E}+03$ & $7.67 E+03$ & $7.70 E+03$ & $7.72 \mathrm{E}+03$ & $7.75 E+03$ & $7.78 \mathrm{E}+03$ \\
\hline $\mathbf{S i}$ & $1.60 \mathrm{E}+01$ & $1.21 E+01$ & $2.41 \mathrm{E}+01$ & $3.62 \mathrm{E}+01$ & $1.30 \mathrm{E}+01$ & $2.74 E+01$ & $4.18 \mathrm{E}+01$ \\
\hline $\mathrm{Ca}$ & $1.22 \mathrm{E}+01$ & $4.34 \mathrm{E}+01$ & $5.55 \mathrm{E}+01$ & $6.83 E+01$ & $2.26 \mathrm{E}+01$ & $3.57 \mathrm{E}+01$ & $4.99 E+01$ \\
\hline $\mathbf{T i}$ & $9.57 \mathrm{E}+02$ & $6.77 \mathrm{E}+01$ & $7.75 \mathrm{E}+01$ & $8.72 \mathrm{E}+01$ & $5.42 \mathrm{E}+01$ & $5.68 \mathrm{E}+01$ & $5.94 \mathrm{E}+01$ \\
\hline V & & $5.17 E+00$ & $9.20 \mathrm{E}+00$ & $1.32 \mathrm{E}+01$ & $1.98 \mathrm{E}+00$ & $3.17 E+00$ & $4.40 \mathrm{E}+00$ \\
\hline $\mathrm{Cr}$ & $6.40 \mathrm{E}+01$ & $9.80 \mathrm{E}+01$ & $1.08 \mathrm{E}+02$ & $1.17 E+02$ & $1.08 \mathrm{E}+02$ & $1.21 E+02$ & $1.33 E+02$ \\
\hline Mn & $1.18 \mathrm{E}+02$ & $2.60 \mathrm{E}+01$ & $2.91 \mathrm{E}+01$ & $3.22 \mathrm{E}+01$ & $3.08 \mathrm{E}+01$ & $3.46 \mathrm{E}+01$ & $3.84 E+01$ \\
\hline $\mathrm{Fe}$ & $5.79 \mathrm{E}+02$ & $6.40 \mathrm{E}+01$ & $8.65 E+01$ & $1.09 E+02$ & $5.75 \mathrm{E}+01$ & $8.00 E+01$ & $1.02 \mathrm{E}+02$ \\
\hline $\mathbf{N i}$ & $5.00 \mathrm{E}+01$ & $1.26 \mathrm{E}+01$ & $1.78 \mathrm{E}+01$ & $2.30 \mathrm{E}+01$ & $1.46 \mathrm{E}+01$ & $2.01 E+01$ & $2.57 \mathrm{E}+01$ \\
\hline Co & $4.00 \mathrm{E}-02$ & $1.13 \mathrm{E}-01$ & $1.62 E-01$ & $2.16 \mathrm{E}-01$ & $1.12 \mathrm{E}-01$ & $1.58 \mathrm{E}-01$ & $2.09 \mathrm{E}-01$ \\
\hline $\mathrm{Cu}$ & $3.70 \mathrm{E}+00$ & $7.64 \mathrm{E}+00$ & $1.33 \mathrm{E}+01$ & $1.89 \mathrm{E}+01$ & $8.98 \mathrm{E}+00$ & $1.63 E+01$ & $2.35 \mathrm{E}+01$ \\
\hline $\mathbf{Z n}$ & $1.28 \mathrm{E}+01$ & $8.17 \mathrm{E}+00$ & $9.03 E+00$ & $9.88 \mathrm{E}+00$ & $8.85 E+00$ & $9.67 \mathrm{E}+00$ & $1.05 \mathrm{E}+01$ \\
\hline As & $4.00 \mathrm{E}-02$ & $5.11 \mathrm{E}+00$ & $6.33 E+00$ & $7.56 \mathrm{E}+00$ & $1.82 \mathrm{E}+00$ & $2.17 E+00$ & $2.52 \mathrm{E}+00$ \\
\hline $\mathrm{Se}$ & $1.00 \mathrm{E}+00$ & $2.88 E+00$ & $5.06 E+00$ & $8.53 E+00$ & $2.58 \mathrm{E}+00$ & $4.70 E+00$ & $8.09 E+00$ \\
\hline $\mathrm{Sr}$ & $1.00 \mathrm{E}-01$ & $1.49 \mathrm{E}+00$ & $2.68 \mathrm{E}+00$ & $3.88 E+00$ & $7.19 \mathrm{E}-01$ & $1.22 E+00$ & $1.72 \mathrm{E}+00$ \\
\hline $\mathrm{Zr}$ & $5.00 \mathrm{E}+01$ & $3.22 \mathrm{E}+00$ & $6.43 E+00$ & $9.77 \mathrm{E}+00$ & $3.97 \mathrm{E}+00$ & $7.55 \mathrm{E}+00$ & $1.12 \mathrm{E}+01$ \\
\hline Mo & $1.20 \mathrm{E}+01$ & $3.23 E+01$ & $3.68 \mathrm{E}+01$ & $4.14 \mathrm{E}+01$ & $3.30 \mathrm{E}+01$ & $3.80 \mathrm{E}+01$ & $4.30 \mathrm{E}+01$ \\
\hline $\mathbf{R u}$ & $5.40 \mathrm{E}+00$ & $3.25 \mathrm{E}+00$ & $3.79 \mathrm{E}+00$ & $4.43 E+00$ & $3.84 \mathrm{E}+00$ & $4.48 \mathrm{E}+00$ & $5.20 \mathrm{E}+00$ \\
\hline $\mathbf{R h}$ & $1.40 \mathrm{E}+00$ & $1.21 E+00$ & $1.35 E+00$ & $1.50 \mathrm{E}+00$ & $1.41 \mathrm{E}+00$ & $1.55 E+00$ & $1.69 \mathrm{E}+00$ \\
\hline $\mathbf{P d}$ & $2.60 \mathrm{E}+00$ & $6.21 \mathrm{E}-02$ & $1.58 \mathrm{E}-01$ & $2.67 \mathrm{E}-01$ & $7.12 \mathrm{E}-02$ & 1.37E-01 & $2.16 \mathrm{E}-01$ \\
\hline Ag & $6.80 \mathrm{E}+00$ & $3.88 \mathrm{E}-01$ & $2.88 E+00$ & $5.95 \mathrm{E}+00$ & $4.40 \mathrm{E}-01$ & $1.81 E+00$ & $3.29 \mathrm{E}+00$ \\
\hline Cd & $4.00 \mathrm{E}-01$ & $6.90 \mathrm{E}-01$ & $1.51 E+00$ & $2.36 \mathrm{E}+00$ & $5.63 \mathrm{E}-01$ & $1.21 E+00$ & $1.88 \mathrm{E}+00$ \\
\hline Sn & $2.10 \mathrm{E}+00$ & $2.81 E+00$ & $3.62 \mathrm{E}+00$ & $4.44 E+00$ & $3.19 \mathrm{E}+00$ & $3.98 \mathrm{E}+00$ & $4.77 \mathrm{E}+00$ \\
\hline $\mathbf{L a}$ & $5.00 \mathrm{E}-02$ & $1.87 E+00$ & $3.05 E+00$ & $4.52 \mathrm{E}+00$ & $2.18 \mathrm{E}+00$ & $3.12 E+00$ & $4.11 \mathrm{E}+00$ \\
\hline $\mathrm{Ce}$ & $3.00 \mathrm{E}-01$ & $1.29 E+01$ & $1.83 E+01$ & $2.38 \mathrm{E}+01$ & $1.46 \mathrm{E}+01$ & $2.08 \mathrm{E}+01$ & $2.69 \mathrm{E}+01$ \\
\hline $\mathbf{W}$ & & 4.62E-01 & $7.63 \mathrm{E}-01$ & $1.07 \mathrm{E}+00$ & $4.75 \mathrm{E}-01$ & 7.32E-01 & $9.91 \mathrm{E}-01$ \\
\hline$\ddot{R e}$ & & $1.10 \mathrm{E}-03$ & $1.58 \mathrm{E}-03$ & $2.08 \mathrm{E}-03$ & $1.45 \mathrm{E}-03$ & $2.08 \mathrm{E}-03$ & $2.73 \mathrm{E}-03$ \\
\hline Os & & $0.00 E+00$ & $2.26 \mathrm{E}-03$ & $9.89 \mathrm{E}-03$ & $0.00 \mathrm{E}+00$ & $2.33 \mathrm{E}-03$ & $1.01 \mathrm{E}-02$ \\
\hline Ir & & $0.00 \mathrm{E}+00$ & $6.74 \mathrm{E}-04$ & $2.61 \mathrm{E}-03$ & $0.00 E+00$ & $7.09 \mathrm{E}-04$ & $2.64 \mathrm{E}-03$ \\
\hline $\mathbf{P t}$ & & $1.23 \mathrm{E}-03$ & $1.28 \mathrm{E}-02$ & $4.59 \mathrm{E}-02$ & $1.62 \mathrm{E}-03$ & $1.48 \mathrm{E}-02$ & $5.22 \mathrm{E}-02$ \\
\hline $\mathbf{A u}$ & & $1.13 \mathrm{E}-03$ & $2.14 E-03$ & $3.81 \mathrm{E}-03$ & $1.29 \mathrm{E}-03$ & $2.45 \mathrm{E}-03$ & $4.25 \mathrm{E}-03$ \\
\hline Hg & $8.48 \mathrm{E}+01$ & $4.11 \mathrm{E}+01$ & $5.37 \mathrm{E}+01$ & $6.64 \mathrm{E}+01$ & $4.36 \mathrm{E}+01$ & $5.75 E+01$ & $7.14 \mathrm{E}+01$ \\
\hline $\mathbf{P b}$ & $6.00 \mathrm{E}+00$ & $4.60 \mathrm{E}+00$ & $6.53 \mathrm{E}+00$ & $8.45 \mathrm{E}+00$ & $4.55 E+00$ & $6.47 E+00$ & $8.39 \mathrm{E}+00$ \\
\hline $\mathbf{U}$ & & $4.24 \mathrm{E}+00$ & $8.27 E+00$ & $1.26 \mathrm{E}+01$ & $4.29 \mathrm{E}+00$ & $6.75 E+00$ & $9.44 E+00$ \\
\hline
\end{tabular}


Appendix 9.12

Calculated Composition of Tests $4 \mathrm{~A}$ and $4 \mathrm{C}$ Slurries

\begin{tabular}{|c|c|c|c|c|c|c|c|}
\hline Element & $\begin{array}{l}\text { ECC } \\
\mathrm{mg} / \mathrm{L}\end{array}$ & $\begin{array}{c}\text { Test 4A } \\
\text { Minimum } \\
\text { mg/L }\end{array}$ & $\begin{array}{c}\text { Test 4A } \\
\text { Average } \\
\text { mg/L }\end{array}$ & $\begin{array}{c}\text { Test 4A } \\
\text { Maximum } \\
\text { mg/L }\end{array}$ & $\begin{array}{c}\text { Test 4C } \\
\text { Minimum } \\
\text { mg/L }\end{array}$ & $\begin{array}{c}\text { Test 4C } \\
\text { Average } \\
\mathrm{mg} / \mathrm{L}\end{array}$ & $\begin{array}{c}\text { Test 4C } \\
\text { Maximum } \\
\text { mg/L }\end{array}$ \\
\hline $\mathbf{M g}$ & $2.00 \mathrm{E}+00$ & $1.60 \mathrm{E}+00$ & $2.62 \mathrm{E}+00$ & $3.65 \mathrm{E}+00$ & $1.61 \mathrm{E}+00$ & $2.62 \mathrm{E}+00$ & $3.64 E+00$ \\
\hline Al & $9.60 E+01$ & $7.66 \mathrm{E}+03$ & $7.69 \mathrm{E}+03$ & $7.71 E+03$ & $7.69 \mathrm{E}+03$ & $7.72 E+03$ & $7.74 E+03$ \\
\hline $\mathbf{S i}$ & $1.60 \mathrm{E}+01$ & $1.09 \mathrm{E}+01$ & $2.48 \mathrm{E}+01$ & $3.87 \mathrm{E}+01$ & $1.09 \mathrm{E}+01$ & $2.46 \mathrm{E}+01$ & $3.84 \mathrm{E}+01$ \\
\hline $\mathrm{Ca}$ & $1.22 \mathrm{E}+01$ & $1.79 \mathrm{E}+01$ & $3.10 \mathrm{E}+01$ & 4.52E+01 & $1.84 \mathrm{E}+01$ & $3.14 E+01$ & $4.55 \mathrm{E}+01$ \\
\hline $\mathbf{T i}$ & $9.57 \mathrm{E}+02$ & $6.25 \mathrm{E}+01$ & $6.51 \mathrm{E}+01$ & $6.77 \mathrm{E}+01$ & $6.35 E+01$ & $6.63 \mathrm{E}+01$ & $6.90 \mathrm{E}+01$ \\
\hline $\mathrm{v}$ & & $1.73 \mathrm{E}+00$ & $2.75 E+00$ & $3.81 E+00$ & $1.80 \mathrm{E}+00$ & $2.89 \mathrm{E}+00$ & $4.01 E+00$ \\
\hline $\mathrm{Cr}$ & $6.40 \mathrm{E}+01$ & $1.09 \mathrm{E}+02$ & $1.21 \mathrm{E}+02$ & $1.34 \mathrm{E}+02$ & $1.09 \mathrm{E}+02$ & $1.21 E+02$ & $1.34 E+02$ \\
\hline Mn & $1.18 \mathrm{E}+02$ & $2.59 \mathrm{E}+01$ & $2.93 E+01$ & $3.27 \mathrm{E}+01$ & $2.58 \mathrm{E}+01$ & $2.91 \mathrm{E}+01$ & $3.25 \mathrm{E}+01$ \\
\hline $\mathrm{Fe}$ & $5.79 \mathrm{E}+02$ & $4.74 \mathrm{E}+01$ & $6.87 \mathrm{E}+01$ & $9.01 \mathrm{E}+01$ & $4.76 \mathrm{E}+01$ & $6.88 \mathrm{E}+01$ & $9.01 E+01$ \\
\hline $\mathbf{N i}$ & $5.00 \mathrm{E}+01$ & $1.17 \mathrm{E}+01$ & $1.72 \mathrm{E}+01$ & $2.27 \mathrm{E}+01$ & $1.17 \mathrm{E}+01$ & $1.71 \mathrm{E}+01$ & $2.25 \mathrm{E}+01$ \\
\hline Co & $4.00 \mathrm{E}-02$ & $8.42 \mathrm{E}-02$ & $1.15 \mathrm{E}-01$ & $1.52 \mathrm{E}-01$ & $8.54 \mathrm{E}-02$ & 1.17E-01 & $1.54 \mathrm{E}-01$ \\
\hline $\mathrm{Cu}$ & $3.70 \mathrm{E}+00$ & $8.62 E+00$ & $1.59 \mathrm{E}+01$ & $2.33 \mathrm{E}+01$ & $8.57 \mathrm{E}+00$ & $1.58 \mathrm{E}+01$ & $2.30 \mathrm{E}+01$ \\
\hline $\mathbf{Z n}$ & $1.28 \mathrm{E}+01$ & $8.94 \mathrm{E}+00$ & $9.74 \mathrm{E}+00$ & $1.05 \mathrm{E}+01$ & $8.88 \mathrm{E}+00$ & $9.68 \mathrm{E}+00$ & $1.05 \mathrm{E}+01$ \\
\hline As & $4.00 \mathrm{E}-02$ & $1.56 \mathrm{E}+00$ & $1.89 \mathrm{E}+00$ & $2.21 \mathrm{E}+00$ & $1.65 \mathrm{E}+00$ & $2.00 \mathrm{E}+00$ & $2.34 E+00$ \\
\hline Se & $1.00 \mathrm{E}+00$ & $2.42 \mathrm{E}+00$ & $4.49 \mathrm{E}+00$ & $7.80 \mathrm{E}+00$ & $2.42 \mathrm{E}+00$ & $4.49 \mathrm{E}+00$ & $7.83 E+00$ \\
\hline $\mathbf{S r}$ & $1.00 \mathrm{E}-01$ & $6.56 \mathrm{E}-01$ & $1.13 E+00$ & $1.60 \mathrm{E}+00$ & $6.72 \mathrm{E}-01$ & $1.16 \mathrm{E}+00$ & $1.65 \mathrm{E}+00$ \\
\hline $\mathbf{Z r}$ & $5.00 \mathrm{E}+01$ & $3.21 \mathrm{E}+00$ & $6.32 \mathrm{E}+00$ & $9.50 \mathrm{E}+00$ & $3.20 \mathrm{E}+00$ & $6.29 E+00$ & $9.46 E+00$ \\
\hline Mo & $1.20 \mathrm{E}+01$ & $3.30 \mathrm{E}+01$ & $3.80 \mathrm{E}+01$ & $4.30 \mathrm{E}+01$ & $3.31 \mathrm{E}+01$ & $3.81 \mathrm{E}+01$ & $4.31 \mathrm{E}+01$ \\
\hline Ru & $5.40 \mathrm{E}+00$ & $2.55 \mathrm{E}+00$ & $3.07 E+00$ & $3.67 \mathrm{E}+00$ & $2.55 \mathrm{E}+00$ & $3.08 \mathrm{E}+00$ & $3.67 E+00$ \\
\hline $\mathbf{R h}$ & $1.40 \mathrm{E}+00$ & $1.14 \mathrm{E}+00$ & $1.26 E+00$ & $1.39 \mathrm{E}+00$ & $1.14 \mathrm{E}+00$ & $1.26 \mathrm{E}+00$ & $1.39 E+00$ \\
\hline $\mathbf{P d}$ & $2.60 \mathrm{E}+00$ & $3.94 \mathrm{E}-02$ & $9.25 \mathrm{E}-02$ & $1.59 \mathrm{E}-01$ & $3.99 \mathrm{E}-02$ & $9.44 \mathrm{E}-02$ & $1.62 \mathrm{E}-01$ \\
\hline $\mathbf{A g}$ & $6.80 E+00$ & $2.29 \mathrm{E}-01$ & $1.09 E+00$ & $2.06 \mathrm{E}+00$ & 2.33E-01 & $1.13 E+00$ & $2.15 E+00$ \\
\hline Cd & $4.00 \mathrm{E}-01$ & $4.24 \mathrm{E}-01$ & $1.06 \mathrm{E}+00$ & $1.73 E+00$ & $4.28 \mathrm{E}-01$ & $1.07 \mathrm{E}+00$ & $1.74 \mathrm{E}+00$ \\
\hline $\mathbf{S n}$ & $2.10 \mathrm{E}+00$ & $2.82 \mathrm{E}+00$ & $3.45 \mathrm{E}+00$ & $4.09 E+00$ & $2.80 \mathrm{E}+00$ & $3.45 E+00$ & $4.09 \mathrm{E}+00$ \\
\hline $\mathbf{L a}$ & $5.00 \mathrm{E}-02$ & $1.35 \mathrm{E}+00$ & $1.94 \mathrm{E}+00$ & $2.57 \mathrm{E}+00$ & $1.36 \mathrm{E}+00$ & $1.96 \mathrm{E}+00$ & $2.62 E+00$ \\
\hline $\mathrm{Ce}$ & $3.00 \mathrm{E}-01$ & $7.75 \mathrm{E}+00$ & $1.09 E+01$ & $1.41 \mathrm{E}+01$ & $7.86 \mathrm{E}+00$ & $1.11 \mathrm{E}+01$ & $1.43 \mathrm{E}+01$ \\
\hline $\mathbf{W}$ & & $4.81 \mathrm{E}-01$ & $7.39 \mathrm{E}-01$ & $9.99 \mathrm{E}-01$ & $4.80 \mathrm{E}-01$ & $7.39 \mathrm{E}-01$ & $1.00 \mathrm{E}+00$ \\
\hline $\operatorname{Re}$ & & $1.48 \mathrm{E}-03$ & 2.12E-03 & $2.79 \mathrm{E}-03$ & $1.46 \mathrm{E}-03$ & $2.09 \mathrm{E}-03$ & $2.75 \mathrm{E}-03$ \\
\hline Os & & $0.00 \mathrm{E}+00$ & $2.32 \mathrm{E}-03$ & $1.00 \mathrm{E}-02$ & $0.00 \mathrm{E}+00$ & $2.34 \mathrm{E}-03$ & $1.01 \mathrm{E}-02$ \\
\hline $\mathbf{I r}$ & & $0.00 \mathrm{E}+00$ & $7.07 \mathrm{E}-04$ & $2.62 \mathrm{E}-03$ & $0.00 \mathrm{E}+00$ & -7.12E-04 & $2.65 \mathrm{E}-03$ \\
\hline $\mathbf{P t}$ & & $1.65 \mathrm{E}-03$ & $9.64 \mathrm{E}-03$ & $3.11 \mathrm{E}-02$ & $1.63 \mathrm{E}-03$ & $9.69 \mathrm{E}-03$ & $3.14 \mathrm{E}-02$ \\
\hline Au & & $7.29 \mathrm{E}-04$ & $1.62 \mathrm{E}-03$ & $3.14 \mathrm{E}-03$ & 7.37E-04 & $1.63 \mathrm{E}-03$ & $3.16 \mathrm{E}-03$ \\
\hline Hg & $8.48 E+01$ & $3.45 \mathrm{E}+01$ & $4.34 E+01$ & $5.23 \mathrm{E}+01$ & $3.49 \mathrm{E}+01$ & $4.39 E+01$ & $5.30 \mathrm{E}+01$ \\
\hline $\mathbf{P b}$ & $6.00 \mathrm{E}+00$ & $3.16 \mathrm{E}+00$ & $4.55 \mathrm{E}+00$ & $5.94 \mathrm{E}+00$ & $3.19 \mathrm{E}+00$ & $4.60 \mathrm{E}+00$ & $6.01 \mathrm{E}+00$ \\
\hline $\mathbf{U}$ & & $3.62 E+00$ & $5.59 E+00$ & $7.79 \mathrm{E}+00$ & $3.62 \mathrm{E}+00$ & $5.63 E+00$ & $7.90 \mathrm{E}+00$ \\
\hline
\end{tabular}




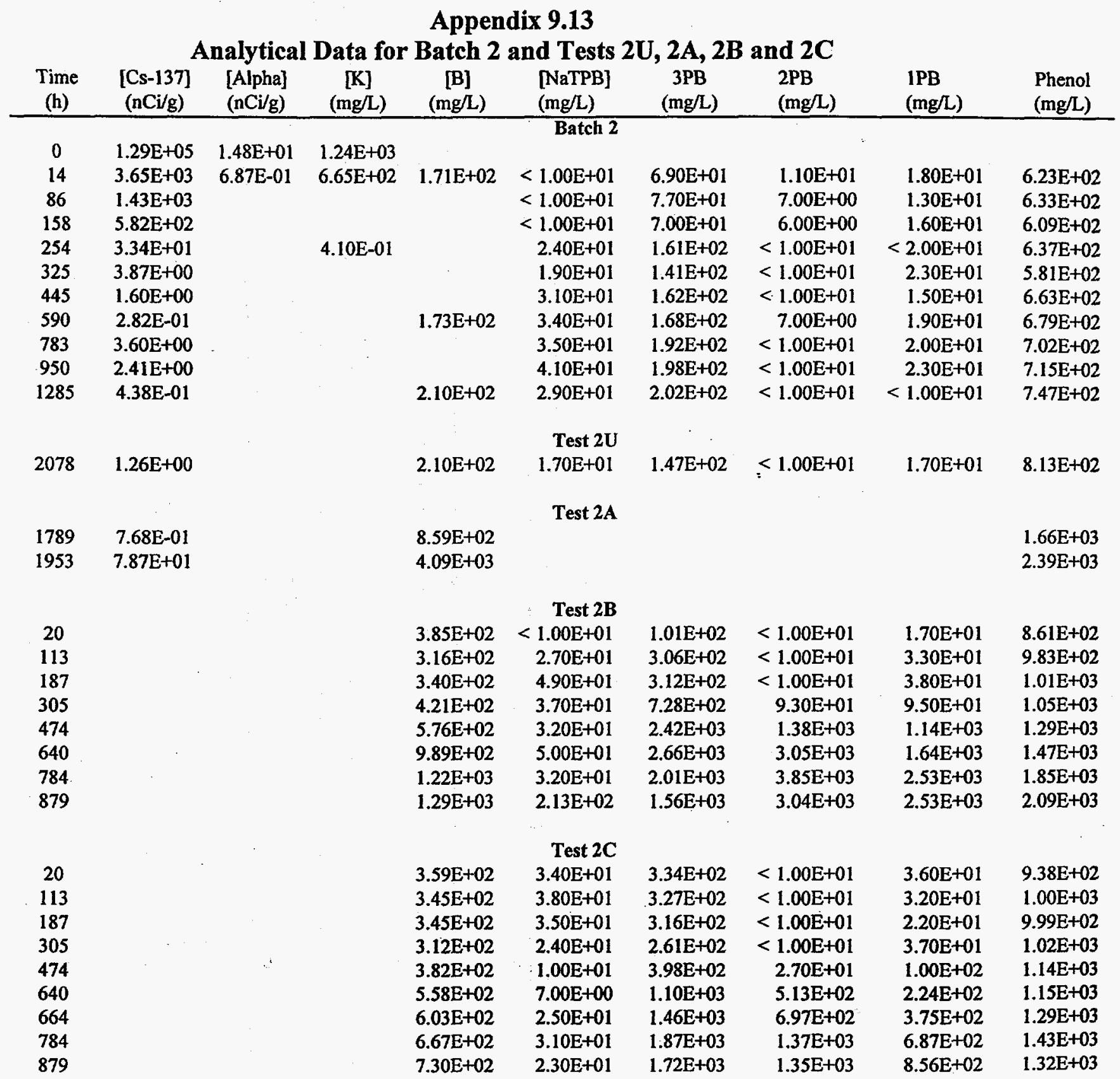

Blank entry indicates measurement not performed 
Appendix 9.14

Analytical Data for Tests 3A, 3B, 3C and 3D

\begin{tabular}{|c|c|c|c|c|c|c|c|}
\hline $\begin{array}{l}\text { Time } \\
\text { (h) }\end{array}$ & $\begin{array}{c}{[\mathrm{Cs}-137]} \\
(\mathrm{nCi} / \mathrm{g})\end{array}$ & $\begin{array}{c}\text { [B] } \\
(\mathrm{mg} / \mathrm{L})\end{array}$ & $\begin{array}{c}\text { [NaTPB] } \\
(\mathrm{mg} / \mathrm{L})\end{array}$ & $\begin{array}{l}\text { [3PB] } \\
(\mathrm{mg} / \mathrm{L})\end{array}$ & $\begin{array}{l}{[2 \mathrm{~PB}]} \\
(\mathrm{mg} / \mathrm{L})\end{array}$ & $\begin{array}{c}{[1 \mathrm{~PB}]} \\
(\mathrm{mg} / \mathrm{L})\end{array}$ & $\begin{array}{c}\text { [Phenol] } \\
(\mathrm{mg} / \mathrm{L})\end{array}$ \\
\hline & & & Test 3A & & & & \\
\hline 22 & $9.05 \mathrm{E}+03$ & 67 & $<50$ & 80 & 80 & 260 & 540 \\
\hline 141 & $1.12 \mathrm{E}+04$ & 365 & $<10$ & 68 & 43 & 208 & 620 \\
\hline 213 & $1.44 \mathrm{E}+04$ & 301 & $<10$ & 48 & 26 & 149 & 638 \\
\hline 362 & $2.04 \mathrm{E}+04$ & 263 & $<10$ & $<10$ & $<10$ & 72 & 724 \\
\hline 618 & $4.83 E+00$ & 450 & 32 & 763 & 699 & 163 & 698 \\
\hline 689 & $3.36 \mathrm{E}+02$ & & & & & & \\
\hline 785 & $3.06 \mathrm{E}+03$ & & $<10$ & $<10$ & 65 & 467 & 1283 \\
\hline 832 & $3.15 \mathrm{E}+03$ & 478 & $<10$ & 8 & 38 & 331 & 1275 \\
\hline \multirow[t]{2}{*}{951} & $5.99 \mathrm{E}+03$ & 431 & $<10$ & $<10$ & $<10$ & 105 & 1501 \\
\hline & & & Test 3B & & & & \\
\hline 22 & $2.03 E+04$ & 61 & $<50$ & $<50$ & $<50$ & 70 & 155 \\
\hline 141 & $2.32 E+04$ & 131 & $<10$ & $<10$ & $<10$ & 69 & 248 \\
\hline 213 & $2.07 \mathrm{E}+04$ & 132 & $<10$ & $<10$ & $<10$ & 54 & 278 \\
\hline 362 & $1.84 \mathrm{E}+04$ & 145 & $<10$ & $<10$ & $<10$ & 33 & 332 \\
\hline 618 & $6.28 \mathrm{E}+00$ & 189 & 12 & 66 & 48 & 25 & 385 \\
\hline 689 & $3.79 \mathrm{E}+00$ & & & & & & \\
\hline 785 & $2.08 \mathrm{E}+00$ & & & & & & \\
\hline 832 & $5.58 \mathrm{E}+00$ & 278 & $<10$ & 14 & 165 & $231^{\circ}$ & 607 \\
\hline \multirow[t]{2}{*}{951} & $1.28 \mathrm{E}+01$ & 268 & $<10$ & $<10$ & 61 & 240 & 822 \\
\hline & & & Test 3C & & & & \\
\hline 22 & $6.20 \mathrm{E}+03$ & 137 & $<10$ & 36 & $<10$ & 34 & 222 \\
\hline 141 & $1.44 \mathrm{E}+03$ & 139 & $<10$ & $<10$ & $<10$ & 22 & 272 \\
\hline 213 & $2.62 \mathrm{E}+01$ & 125 & $<10$ & $<10$ & $<10$ & 30 & 273 \\
\hline 362 & $2.45 \mathrm{E}+02$ & 146 & $<10$ & $<10$ & 71 & 63 & 354 \\
\hline 618 & $2.60 \mathrm{E}+01$ & 235 & $<10$ & 52 & 224 & 131 & 546 \\
\hline 689 & $1.43 E+03$ & & & & & & \\
\hline 785 & $4.71 E+03$ & & & & & & \\
\hline 832 & $6.22 \mathrm{E}+03$ & 254 & $<10$ & $<10$ & $<10$ & 59 & 779 \\
\hline \multirow[t]{2}{*}{951} & $9.68 \mathrm{E}+03$ & 245 & $<10$ & $<10$ & $<10$ & 29 & 856 \\
\hline & & & Test 3D & & & & \\
\hline 22 & $5.76 \mathrm{E}+04$ & 124 & $<10$ & $<10$ & $<10$ & 32 & 104 \\
\hline 141 & $4.48 \mathrm{E}+04$ & 110 & $<10$ & $<10$ & $<10$ & 20 & 153 \\
\hline 213 & $4.52 \mathrm{E}+04$ & 96 & $<10$ & $<10$ & $<10$ & $<10$ & 158 \\
\hline 362 & $4.16 \mathrm{E}+04$ & 132 & $<10$ & $<10$ & $<10$ & $<10$ & 171 \\
\hline 618 & $1.27 \mathrm{E}+00$ & 156 & 14 & 45 & 11 & $<10$ & 201 \\
\hline 691 & $1.81 \mathrm{E}+01$ & & & & & & \\
\hline 785 & $1.86 \mathrm{E}+00$ & & & & & & \\
\hline 832 & $2.49 \mathrm{E}+00$ & 104 & 24 & 69 & $<10$ & $<10$ & 281 \\
\hline 951 & $1.01 \mathrm{E}+01$ & 140 & 13 & 62 & $<10$ & $<10$ & 299 \\
\hline 1504 & $7.98 \mathrm{E}+00$ & 302 & $<10$ & 23 & $<10$ & 21 & 541 \\
\hline 1671 & $6.51 E+00$ & 266 & $<10$ & 25 & $<10$ & $<10$ & 558 \\
\hline 1793 & $4.26 \mathrm{E}+00$ & 266 & $<10$ & $<10$ & $<10$ & $<10$ & 578 \\
\hline
\end{tabular}

\footnotetext{
Blank entry indicates measurement not performed
} 


\begin{tabular}{|c|c|c|c|c|c|c|c|c|}
\hline $\begin{array}{l}\text { Time } \\
\text { (h) }\end{array}$ & $\begin{array}{c}{[\mathrm{Cs}-137]} \\
(\mathrm{nCi} / \mathrm{g})\end{array}$ & $\underset{[\mathrm{K}]}{\text { Analy }}$ & $\begin{array}{c}\text { AI } \\
\text { l Data } \\
{[\mathrm{B}]} \\
(\mathrm{mg} / \mathrm{L})\end{array}$ & $\begin{array}{c}\text { ndix } 9.15 \\
\text { r Tests } 4 \\
\text { [NaTPB] } \\
(\mathrm{mg} / \mathrm{L})\end{array}$ & $\begin{array}{c}4 \mathrm{C} \text { anc } \\
{[3 \mathrm{~PB}]} \\
(\mathrm{mg} / \mathrm{L})\end{array}$ & $\begin{array}{c}{[2 \mathrm{~PB}]} \\
(\mathrm{mg} / \mathrm{L})\end{array}$ & $\begin{array}{l}{[1 \mathrm{~PB}]} \\
(\mathrm{mg} / \mathrm{L})\end{array}$ & $\begin{array}{l}\text { [Phenol] } \\
\text { (mg/L) }\end{array}$ \\
\hline \multicolumn{9}{|c|}{ Test $4 A$} \\
\hline 18 & $1.43 \mathrm{E}+03$ & 173 & 275 & $<10$ & 39 & 48 & 21 & 365 \\
\hline 185 & $1.56 \mathrm{E}+01$ & 137 & 271 & 18 & 127 & 190 & 129 & 456 \\
\hline 308 & $4.35 \mathrm{E}+01$ & 157 & 347 & $<10$ & 143 & 403 & 306 & 602 \\
\hline 377 & $2.92 \mathrm{E}+02$ & 4 & 360 & $<10$ & $<10$ & 325 & 381 & 623 \\
\hline 472 & $1.25 \mathrm{E}+03$ & 152 & 268 & $<10$ & $<10$ & 87 & 304 & 727 \\
\hline 666 & $3.49 E+03$ & 192 & 372 & $<10$ & 20 & $<10$ & 73 & 843 \\
\hline 811 & $6.95 E+03$ & 173 & 379 & $<10$ & $<10$ & $<10$ & 40 & 920 \\
\hline 884 & $9.57 \mathrm{E}+03$ & & & & & & & \\
\hline \multicolumn{9}{|c|}{ Test 4C } \\
\hline 18 & 4.77E+05 & 1652 & 705 & $<100$ & $<100$ & $<100$ & $<100$ & 151 \\
\hline 185 & $9.32 \mathrm{E}+05$ & 1697 & 546 & $<99$ & $<100$ & $<100$ & $<100$ & 149 \\
\hline 308 & $6.77 \mathrm{E}+00$ & 163 & 246 & 21 & 111 & $<10$ & 19 & 378 \\
\hline 377 & $2.36 \mathrm{E}+01$ & 3 & 233 & 23 & 110 & $<10$ & $<10$ & 398 \\
\hline 472 & $7.52 \mathrm{E}+00$ & 145 & 206 & 18 & 121 & $<10$ & 19 & 445 \\
\hline 666 & $3.66 \mathrm{E}+00$ & 58 & 314 & $<10$ & 116 & 95 & 73 & 543 \\
\hline 811 & $1.18 \mathrm{E}+01$ & 130 & 208 & $<10$ & 190 & 188 & 146 & 729 \\
\hline 977 & $1.57 \mathrm{E}+01$ & 86 & 332 & $<10$ & 123 & 204 & 246 & 1032 \\
\hline 1145 & $1.29 \mathrm{E}+01$ & 103 & 425 & $<10$ & $<10$ & 91 & 232 & 1632 \\
\hline \multicolumn{9}{|c|}{ Test 2.7} \\
\hline 22 & $7.62 \mathrm{E}+00$ & & 915 & 452 & 3704 & 1034 & 2069 & 1928 \\
\hline 141 & $1.19 \mathrm{E}+01$ & & 1008 & 105 & 4513 & 1225 & 1853 & 2507 \\
\hline 213 & $3.06 E+01$ & & 1053 & 105 & 3400 & 1102 & 1116 & 2562 \\
\hline 362 & $8.34 \mathrm{E}+01$ & & 1172 & $<10$ & 2175 & 690 & 1189 & 3531 \\
\hline 618 & $2.17 \mathrm{E}+02$ & & 1232 & $<10$ & 922 & 132 & 242 & 4474 \\
\hline 691 & $2.93 E+02$ & & & & & & & \\
\hline 785 & $8.70 \mathrm{E}+01$ & & & & & & & \\
\hline 832 & $2.19 \mathrm{E}+01$ & & 1302 & $<10$ & 583 & $<10$ & $<10$ & 5393 \\
\hline
\end{tabular}

Blank entry indicates measurement not performed 


\title{
Appendix 9.16 \\ Radiation Dose Measurements in the SRTC Shielded Cells Facility
}

\begin{abstract}
Recent thermoluminescent dosimetry measurements in B-Block of the SRTC Shielded Cells Facility indicate external radiation doses do not significantly increase the radiation observed by samples processed in Cell \#11 for the Cycle 1 Demonstration. Measured external doses in the range of 1 to $20 \mathrm{rad} / \mathrm{h}$ prove lower than the calculated doses in the range of 90 to 1,500 $\mathrm{rad} / \mathrm{h}$ from internal or self-irradiation of real waste samples based on the analyzed Cs-137 radioactivity.

\section{Introduction}

Since December of 1995, the Waste Processing Technology Section has investigated the decomposition of sodium tetraphenylborate in support of the In-Tank Precipitation (ITP) facility[1,2]. Testing involved both simulated, non-radioactive matrixes typically performed in standard laboratories, and also radioactive waste tests[3-5] conducted in the SRTC Shielded Cells Facility. The referenced radioactive material tests all occurred in Cell \#11, BBlock. This appendix reports the results of radiation dosimetry measurements performed within the Shielded Cells. These dose measurements help access whether the background or external dose rates experienced inside the Shielded Cells Facility exceed the internal, or selfirradiation, dose rates calculated from the sample compositions. If external doses within the Cells remain be less than or near the doses calculated from the radioactive samples themselves, then the radioactive waste tests should depend strongly upon the Shielded Cells environment. The tasks for this study included the following.
\end{abstract}

- Calculate internal dose rates from previous testing of radioactive waste samples in the Shielded Cells based on analyzed specific Cs-137 activities.

- Measure the external doses at several different locations within the Shielded Cells Facility in close proximity to Cell \# 11, B-Block.

- Compare the two dose rates to ascertain if the Shielded Cells environment possibly influenced the experiments.

\section{Results Internal Self-Irradiation Dose Rates from Previous Radioactive Waste Tests Testing in the Shielded Cells typically involves filtration of the $[\mathrm{Na}, \mathrm{K}] \mathrm{TPB}$ slurries with subsequent analysis of the filtrate to determine the Cs-137 specific activities [3-5]. Table 9.16.1 shows results from such analyses. The table also lists maximum values reported for soluble Cs-137; in units of $\mathrm{hCi} / \mathrm{mL}$, from the previous investigations. The table also gives an estimated upper limit for specific Cs-137 activity (i.e., about $4 \mathrm{Ci} /$ gallon) in the current Tank $48 \mathrm{H}$ contents [4]. Note that the dose rate value calculated for this sample, which involves total Cs-137 from the CsTPB solids as well as any soluble Cs-137 in the filtrate, should represent the maximum dose rate for any radioactive waste sample yet tested in the Shielded Cells. The following example, using the $4 \mathrm{Ci} /$ gallon Cs- 137 value, shows how to calculate internal sample dose rates.}

Dose rate $(\mathrm{rad} / \mathrm{h})=4 \mathrm{Ci} / \mathrm{gal} \times 4.84$ watts $/ 1000 \mathrm{Ci} \mathrm{Cs}-137 \times(1 \mathrm{eV} / \mathrm{s} / 1.602 \mathrm{E}-19$ watts $) \times 3600 \mathrm{~s} / \mathrm{h}$ 


$$
\begin{aligned}
& =4.35 \mathrm{E}+20 \mathrm{eV} / \mathrm{gal}-\mathrm{hr} \times 1 \mathrm{gal} / 3.785 \mathrm{~L} \times 1 \mathrm{~L} / 1200 \mathrm{~g} \mathrm{x} 1 \mathrm{rad} / 6.24 \mathrm{E}+13 \mathrm{eV} / \mathrm{g} \\
& =1.53 \mathrm{E}+03 \mathrm{rad} / \mathrm{h}
\end{aligned}
$$

The dose calculated above represents the total combined dose from both the beta-emitter, Cs-137, and its gamma-emitter meta-stable daughter product, Ba-137m. For the typical radioactive waste experiment conducted in $\sim 100$ - $\mathrm{mL}$ glass or carbon-steel vessels, the system absorbs most or all of the beta decay energy whereas a fraction of the gamma decay energy could escape the relatively small glass or carbon-steel vessel systems.

Table 9.16.1. Self-Irradiation Dose Rates from Soluble Cs-137 Radioactive Waste Tests

$\begin{array}{lll}\text { Investigation } & \text { Cs-137,(nCi/mL) } & \text { Dose Rate, }(\mathrm{rad} / \mathrm{h}) \\ \text { WSRC-TR-96-0190 } & 3 \mathrm{E}+05 & 430 \\ \text { WSRC-TR-97-0185 } & 1 \mathrm{E}+05 & 144 \\ \text { WSRC-RP-97-0059 } & 6.9 \mathrm{E}+04 & 91 \\ \text { Tank 48Hb } & 1.1 \mathrm{E}+06 & 1,500 \\ & & \\ \text { : See data relevant to Cycle 1 Demonstration contained within this report. } \\ \begin{array}{l}\text { Derived from the } 4 \text { Ci/gallon Cs-137 specific activity cited in Figure } 4 \text { of Walker, } \\ \text { WSRC-TR-97-0185. }\end{array}\end{array}$

External Dose Rates in Shielded Cells Facility

Dosimetry performed dosimetry in Cell Block B of the Shielded Cells Facility using Panasonic UD-802 Thermoluminescent Dosimiters (TLDs), which are the dosimeters used for routine personnel monitoring on a quarterly basis at Savannah River Site. These dosimeters contain four elements, two different natural lithium borate crystals and two different calcium sulfate crystals, housed in a plastic case with various filters of differing thickness that cover the crystals[6]. The TLDs discriminate between gamma-X-rays and beta particles. The measurement linear response range of the UD-802 TLD falls between 0.010$1,000 \mathrm{rem}$. External Dosimety personnel in Building 735-2B prepared and read the TLDs after exposure using a Panasonic UD-710A Automatic TLD Reader using Department of Energy Laboratory Accreditation Program (DOELAP) protocols (see Chapter 13 : External Dosimetry DOELAP Accreditation and Intercomparison Programs in reference 6).

Dosimetry measurements used a single TLD at each of four different locations within BBlock as detailed in Figure 9.16.1. Personnel double-bag sealed individual TLDs with plastic bags prior to entry into the cells. This allowed one to smear and clear the bags for any 
contamination upon removal from the cells. All four TLDs entered through the port of Cell \# 7. Dose measurements occurred over a six hour period. Cells \# 7-16 comprise the B-Block of the Shielded Cells Facility. TLD \#1 remained in the Cell \#7 entry port, separated from the Cell by a lead door, the entire six hour dose measurement period. We placed TLD \#2 at the upper level of Cell \#11 (i.e., $\sim 12$ feet from the oven used for the Cycle 1 Demonstration) by resting it on an electrical receptacle. TLD \#3 rested on the floor of Cell \#11 adjacent to seven different bottles containing $0.1 \mathrm{~L}$ to $4 \mathrm{~L}$ of residual material from Tank $48 \mathrm{H}$. This TLD (\#3) and Tank 48H material rested within about 2 feet of the oven used in all of the radioactive waste testing to date. Two carbon-steel vessels, with Cycle 1 Demonstration material, resided inside the oven on the day of the dosimetry. A final TLD \#4 rested on the floor of Cell \# 15. This cell contains a significant amount of highly radioactive material stored underneath the cell floor.

Table 9.16.2 lists the measured doses accumulated by each TLD over the six hour period. Analysis of the various element responses for each individual TLD indicates that all four TLDs absorbed predominately gamma-X-rays rather than beta-particle doses. TLD \#1 represents a measurement of the background residual radiation present in the Cell \#7 entry port. This entry port is routinely used for sample transfer in and out of the B-Block Shielded Cells. When not in use, this port is shielded by a lead door. The lead door was closed to the entry port during the present six hour TLD measurement. TLDs \#2 and \#3 likely absorb some of the escaping gamma energy from the various radioactive sources contained within Cell \#11. Note that the measured dose rates in the range of 1 to $18 \mathrm{rem} / \mathrm{h}$ only represent fractions of the calculated total (beta plus gamma) dose rates obtained for the real waste samples shown above in Table 9.16.1. TLD \#4 likely represents one of the highest radiation fluxes within B-Block Cells. Note that the total measured dose for TLD \#4 also exceeded the suggested maximum linear range for this TLD $(1,000 \mathrm{rem})$. Since the radiation intensity decreases inversely with the square distance from its source and since three cells separate Cell \#11 and Cell \# 15, the higher measured radiation dose from Cell \#15 likely contributed little to the measured doses within Cell \#11. (The measurement in Cell \# 15 supports work in another program.). 
Table 9.16.2. Total Dose and Dose Rates for TLDs Stored in B-Block

$\begin{array}{llll}\text { TLD } & \text { Location } & \frac{\text { Total Dose }}{(\mathrm{rem})^{\mathrm{a}}} & \frac{\text { Dose Rate }}{(\mathrm{rem} / \mathrm{h})^{\mathrm{a}}} \\ \# 1 & 0.672 & 0.112 \\ \# 2 & \begin{array}{l}\text { Cell \#7 Entry port } \\ \text { Cell \#11, Upper back }\end{array} & 6.747 & 1.124 \\ \text { left corner } & 111.9 & 18.66 \\ & \begin{array}{l}\text { Cell \#11, Cell floor } \\ \text { near real waste and } \\ \text { testing oven }\end{array} & & \\ \text { C4 } & \text { Cell \# 15, Cell floor } & 2,226 & 371.0 \\ \text { a Absorbed doses reported by External Dosimetry personnel in units of rem. These values } \\ \text { nearly equal rad units since the analysis shows the highly penetrating gamma-X-rays } \\ \text { provide the dominant source of radiation. }\end{array}$

\section{Conclusions}

Researchers measured the external dose rates applicable to Cell \#11 in B-Block of the Shielded Cells Facility at SRTC. Measured external dose rates as determined by TLD dosimeters represent only fractions of calculated internal self-irradiation dose rates from Cycle 1 Demonstration and previous test samples. Thus, the Shielded Cells environment has minimal influence on the experiments. Present TLD dosimetry measurements proved rather easy to obtain in a typical one day-shift time period with subsequent analysis of the results within a few days. Periodic measurements of this type for future experiments will ensure that changes in cell inventory, equipment positioning, or samples will not alter this conclusion.

\section{$\underline{\text { References }}$}

1. A. L. Watkins, DNFSB Recommendation 96-1 Implementation Plan, DOE-SR Memorandum to S. P. Cowan, October 21, 1996.

2. D. D. Walker, M. J. Barnes, C. L. Crawford, R. F. Swingle, R. A. Peterson, M. S. Hay, and S. D. Fink, Decomposition of Tetraphenylborate in Tank 48H (U), WSRC-TR-960113, Rev 0, May 10, 1996.

3. D. D. Walker, C. A. Nash, Results From the Tank $48 \mathrm{H}$ Slurry Demonstration and Decomposition Experiments in Support of ITP Process Verification Testing (U), WSRCTR-96-0190, September 6, 1996.

4. D. D. Walker, Tetraphenylborate Solids Stability Tests (U), WSRC-TR-97-0185, June 25, 1997.

5. M. J. Barnes, D. T. Hobbs, Task Technical Plan for Radioactive Tests in Support of the In-Tank Precipitation Facility (U), WSRC-RP-97-0059, Rev. 1, November 26, 1997.

6. Savannah River Site External Dosimetry Technical Basis Manual (U), WSRC-IM-92101, Rev. 4, Apríl 21, 1997. 
Figure 9.16.1. Schematic Drawings of Dosimeter Locations in Shielded Cells Facility

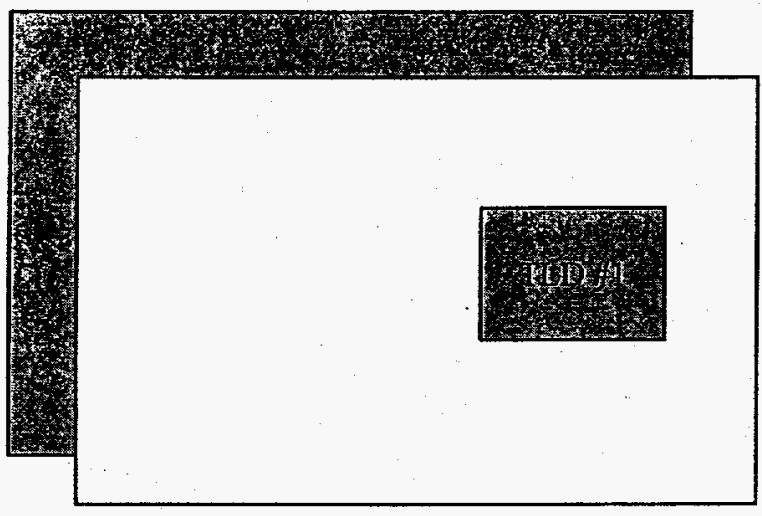

\section{Cell Block B,} Cell \# 7

TLD \# 1 located in entry port,behind lead port door, rear of Cell \#7

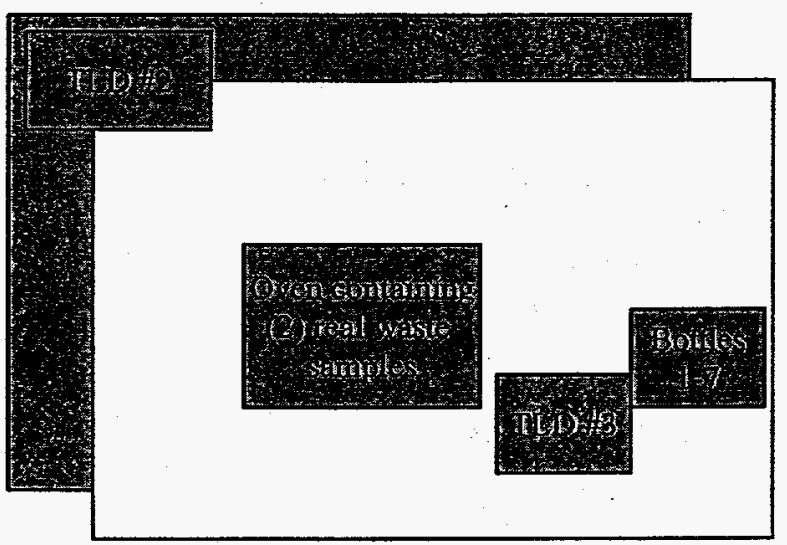

\section{Cell Block B,} Cell \# 11

TLD \#2 located at top, back left corner of Cell \#11

TLD \#3 located between oven and 7 storage bottles containing radioactive waste in mid-right of Cell \#11

\section{Cell Block B, Cell \# 15}

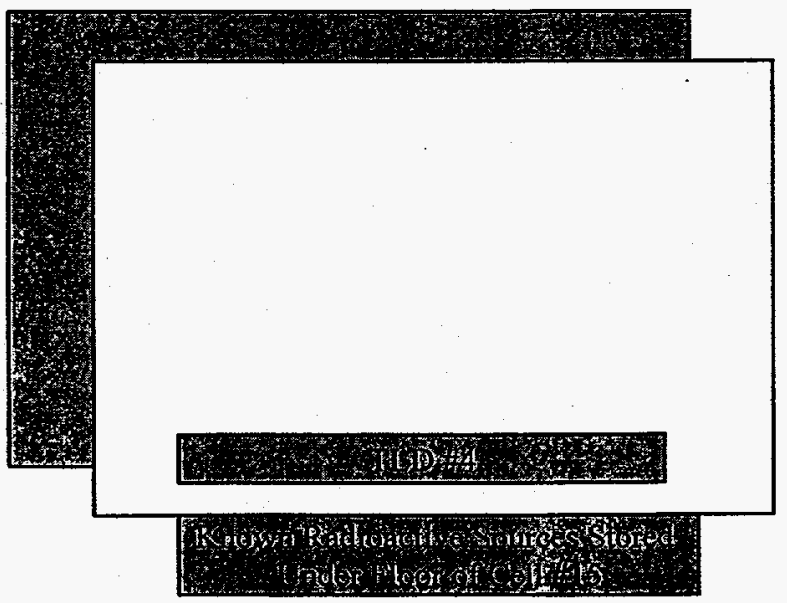

TLD \#4 located on floor in middle of Cell \# 15 
Appendix 9.17

\section{Boron Leaching from Glass Vessels}

The highly alkaline waste solutions leach boron from the borosilicate glass vessels used in the radioactive tests. Two leaching tests, one at $45^{\circ} \mathrm{C}$ and one at $55^{\circ} \mathrm{C}$, conducted to correct the soluble boron results for boron leaching from glass. The leaching tests consisted of placing a synthetic Batch 2 Feed salt solution in the appropriate glass vessel, heating to temperature and periodically samping and analyzing the liquid phase for soluble boron concentration.

Table 9.16.1 provides a list of the salts and concentrations used to prepare the synthetic salt solution. The solution volumes in the leaching tests were selected to provide the same surface area to volume ratios as in the radioactive tests. The boron concentration versus time data linearly regressed (see Figure 9.16.1) to provide a boron leaching rate, $\mathrm{mg} / \mathrm{L}-\mathrm{hr}$ (see Table 9.16.2). Soluble boron concentrations corrected in the radioactive tests by subtracting the calculated soluble boron due to leaching. The calculated soluble boron from leaching determined by multiplying the time in hours when the sample taken by the appropriate boron leach rate. Uncorrected and corrected soluble boron concentrations for Batch 2, Test $2 \mathrm{U}$ and Tests $2 \mathrm{~A}$ are provided in Table 9.16.3.

Table 9.17.1. Composition of Synthetic Batch 2 Feed Solution

$\begin{array}{cc}\stackrel{\text { Salt }}{\mathrm{NaOH}} & \text { Concentration (M) } \\ \mathrm{NaNO}_{3} & 2.8 \\ \mathrm{NaNO}_{2} & 0.60 \\ \mathrm{Na}_{2} \mathrm{CO}_{3} & 0.72 \\ \mathrm{NaAl}(\mathrm{OH})_{4} & 0.28 \\ & 0.20\end{array}$


Figure 9.17.1. Soluble Boron Concentration Versus Time

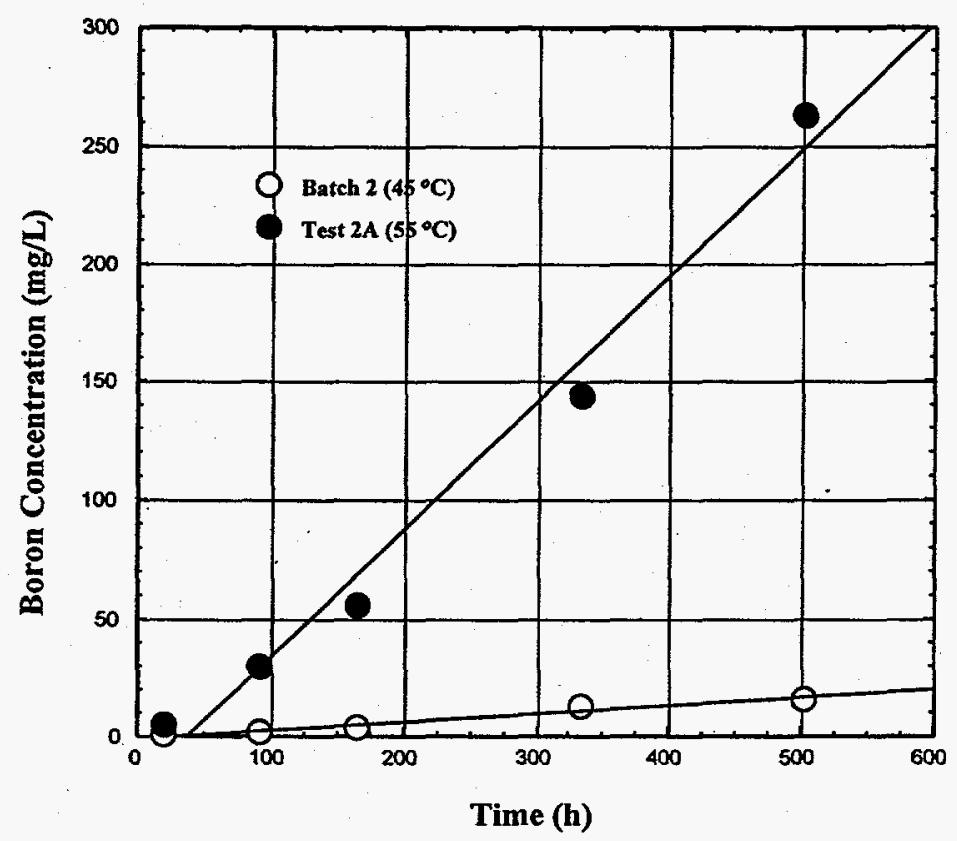

Table 9.17.2. Boron Leaching Rates

$\begin{array}{cc}\text { Temperature } & \text { Boron Leaching Rate }(\mathrm{mg} / \mathrm{L}-\mathrm{h}) \\ 45^{\circ} \mathrm{C} & 3.46 \mathrm{E}-02 \\ 55^{\circ} \mathrm{C} & 5.37 \mathrm{E}-01\end{array}$

Table 9.17.3. Uncorrected and Corrected Soluble Boron Concentrations in Batch 2, Test 2U and Test 2A.

\begin{tabular}{lccc} 
Test ID & Time (h) & $\begin{array}{c}\text { Soluble Boron (mg/L) } \\
\text { Uncorrected }\end{array}$ & $\begin{array}{c}\text { Corrected } \\
\text { Batch 2 }\end{array}$ \\
\cline { 2 - 3 } & 14 & 171 & 171 \\
& 591 & 193 & 173 \\
& 1285 & 255 & 210 \\
Test 2U & 2078 & 282 & 210 \\
Test 2A & 1789 & 1200 & 859 \\
& 1953 & 4520 & 4090
\end{tabular}




\section{Appendix 9.18 \\ Estimation of Benzene Generation Rate from Appearance of Cs-137 in Filtered Supernatant Liquid}

During Batch 1 operations in Tank $48 \mathrm{H}$, cesium and potassium were observed to increase in filtered slurry samples[1,2]. Figure 9.17 .1 contains a plot of the ratio of cesium-137 to potassium (in curies per kilogram) as a function of the total soluble potassium concentration. Averaging these data (excluding the first five data points for the pre PVT-1 dataset due to insufficient soluble cesium) produces and average cesium to potassium ratio of $60 \mathrm{Ci} / \mathrm{kg}$. If the assumption is made that this ratio is representative of universal slurry behvior, it is possible to produce a estimate of the potassium tetraphenylborate decomposition rate based on observed cesium ingrowth. This estimate is of the nature:

$$
\frac{d K}{d t}(m g / L / h r)=\frac{d C s}{d t}(n C i / g / h r) * \frac{k g K}{60 C i C s .} * \frac{1}{\rho(g / m L)}
$$

One can then convert from potassium tetraphenylborate rate to an estimate of the benzene production rate through the following:

$\frac{d \text { Benzene }}{d t}(m g / L / h r)=\frac{d K}{d t}(m g / L / h r) * \frac{1 m \text { mole }}{39 m g} * \frac{78 * 4 m g \text { Benzene }}{\text { mmole }}$ 
Figure 9.17.1. Cesium to Potassium Ratio Versus Potassium Concentration in Tank 48H

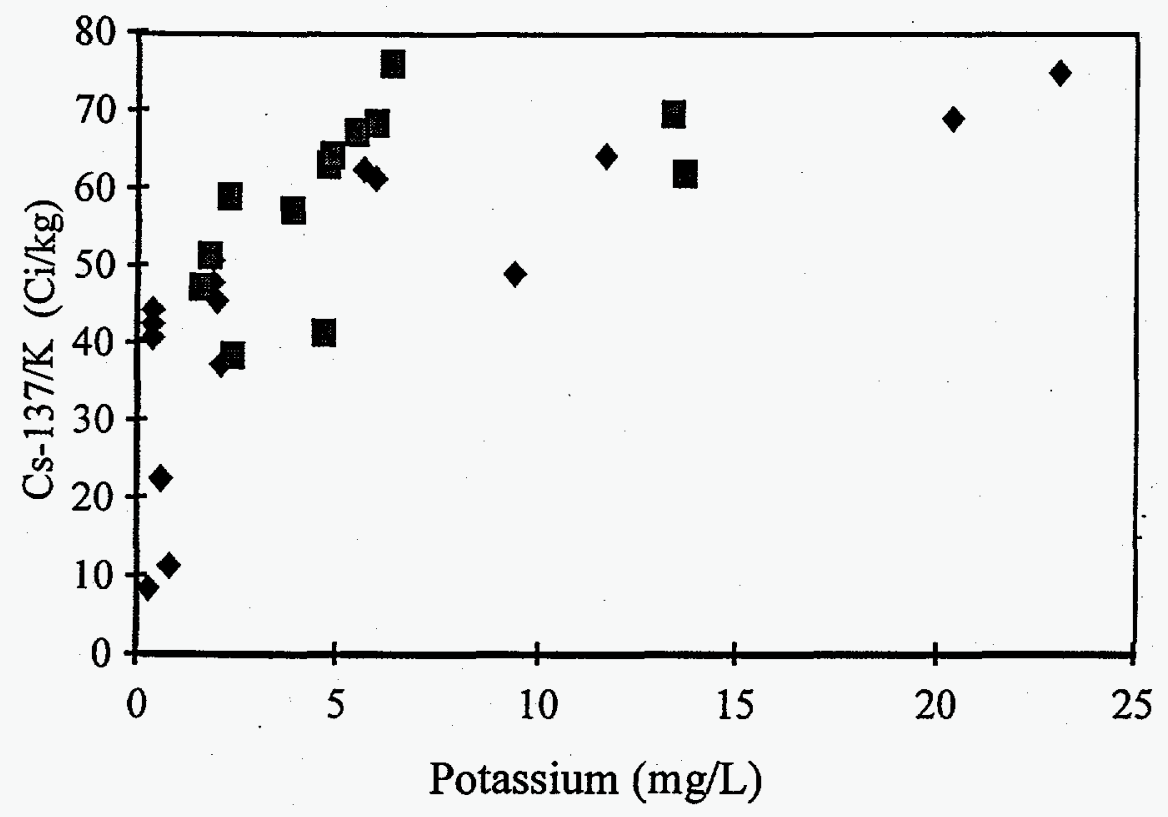

- Pre PVT-1 Tes Post PVT-1 Te

References

1. D. D. Walker, M. J. Barnes, C. L. Crawford, R. F. Swingle, R. A. Peterson, M. S. Hay and S. D. Fink, "Decomposition of Tetraphenylborate in Tank 48H (U)," WSRC-TR-960113, revision 0, May 10, 1996.

2. D. D. Walker, W. T. Boyce, C. J. Coleman, D. P. Diprete, A. A. Ekechukwu, C. W. Hsu, S. F. Peterson, R. J. Ray, L. L. Tovo, M. J. Whitaker and J. E. Young, "Analytical Results for Samples from Process Verification Test, Phase 1 (U),"WSRC-TR-97-0041, revision 0, February 21, 1997. 
CC: B. N. Attaway, 773-A M. J. Barnes, 773-A

J. D. Carlson, 703-H

G. L. Cauthen, 241-119H

W. C. Clark, 704-56H

C. L. Crawford, 773-41A

D. E. Doughty, 704-56H

R. E. Eibling, 704-T

S. D. Fink, 773-A

J. C. Griffin, 773-A

D. T. Hobbs, 773-A

R. A. Jacobs, 704-T

M. T. Keefer, 241-153H

L. F. Landon, 704-T

T. J. Lex, 703-H

D. J. McCabe, 773-43A

M. S. Miller, 704-56H

M. J. Montini, 704-56H

C. A. Nash, 773-42A

L. M. Papouchado, 773-A

S. F. Piccolo. 704-56H

M. J. Polochko, 773-A

P. L. Rutland, 241-152H

P. C. Suggs, 703-H

W. L. Tamosaitis, 773-A

W. B. Van Pelt, 676-1T

W. R. Wilmarth, 773-42A

TIM, 703-43A

WPTS Files, 773-A

ITP Files, c/o A. G. Wiest, 241-119H
J. L. Barnes, 704-S

N. E. Bibler, 773-A

J. T. Carter, 704-25S

M. C. Chandler, 703-H

P. F. Cloessner, 773-A

N. R. Davis, 703-H

L. O. Dworjanyn, 779-2A

H. H. Elder, 704-S

J. R. Fowler, 703-H

M. J. Hitchler, 992-3W

E. W. Holtzscheiter, 773-A

M. D. Johnson, 703-H

P. S. Kirkland, 703-46A

B. L. Lewis, 703-H

P. E. Lowe, 773-41A

J. W. McCollough, 703-H

T. M. Monahon, 703-H

J. P. Morin, 703-H

L. M. Nelson, 773-43A

R. A. Peterson, 773-A

M. R. Poirier, 676-T

C. T. Randall, 704-T

W. E. Stevens, 773-A

R. F. Swingle, 773-A

K. Thomas, 992-3W

D. D. Walker, 773-A

G. T. Wright, 773-A 